\title{
ESPÉCIES DE TRIPES (THYSANOPTERA, THRIPIDAE) ASSOCIADAS A ALGUMAS CULTURAS NO BRASIL
}

RENATA CHIARINI MONTEIRO

Engenheira Agrônoma

Orientador: Prof. Dr. ROBERTO ANTONIO ZUCCHI

Dissertação apresentada à Escola Superior de Agricultura "Luiz de Queiroz", Universidade de São Paulo, para a obtenção do título de Mestre em Ciências - Área de Concentração - Entomologia.

\section{PIRACICABA}

Estado de São Paulo - Brasil

Outubro - 1994 
Ficha catalogratica preparada pela Seço de Livros da

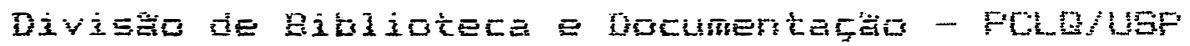

\footnotetext{
Monteiro, Fenaka Chisarini

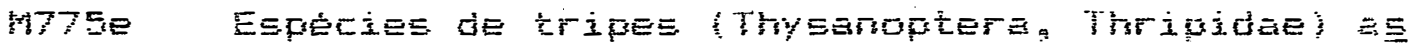

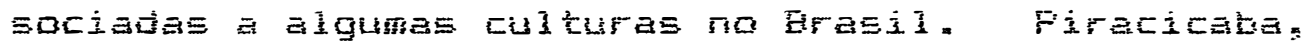
1998.

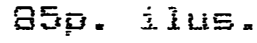

Diss (riestre) - ESALE

Sibligoratia.

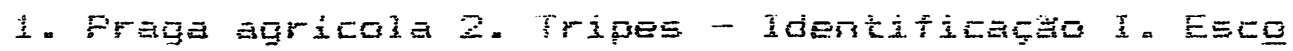
ia Superior de Agricultura luiz de dueiros, firacicaba

CDD 595.751 632.731
} 


\title{
ESPÉCIES DE TRIPES (THYSANOPTERA, THRIPIDAE) ASSOCIADAS A ALGUMAS CULTURAS NO BRASIL
}

\author{
RENATA CHIARINI MONTEIRO
}

Aprovada em: 15 de dezembro de 1994

Comissão julgadora:

Prof. Dr. Roberto Antonio Zucchi

ESALQ/USP

Prof. Dr. Sérgio Antonio Vanin

Inst. Biociências/USP

Prof. Dr. Carlos H. W. Flechtmann

ESALQ/USP

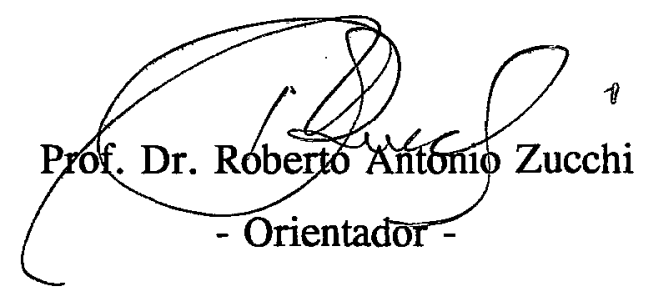


Aos meus pais,

AILTON e MARIA EUDULIA, irmãos,

CLÁUDIA, FERNANDO e ANDRÉ,

e avós,

MARIA DO CARMO e PERPÉTUA,

pelo acompanhamento, apoio e incentivo

proporcionados durante toda minha vida,

OFEREÇO.

Às pessoas a quem amo,

DEDICO. 


\section{AGRADECIMENTOS}

Ao Prof. Dr. Roberto Antonio Zucchi, pela orientação, amizade, acompanhamento e apoio durante todo o período de estudos.

Ao Dr. Laurence A. Mound do "The Natural History Museum", pela indispensável participação nas identificações, ensinamentos e incentivo.

Aos Drs. Sueo Nakahara e Roberto M. Johansen, pelo auxílio nas identificações.

Ao Prof. Dr. Sinval Silveira Neto, pela amizade, acompanhamento dos estudos e iniciação na área de Entomologia.

Ao Prof. Dr. Evôneo Berti Filho, pela amizade e incentivo.

Aos professores do Departamento de Entomologia da ESALQ/USP, pelos ensinamentos.

Ao amigo Fernando Luís Cônsoli, pela convivência, companheirismo, incentivo e participação.

Aos amigos do Departamento de Entomologia, pelo companheirismo, incentivo e carinho.

Aos colegas do Departamento de Entomologia, pela convivência.

Aos funcionários do Departamento de Entomologia da ESALQ/USP, especialmente ao Heraldo, João, Cibele, Regina e Ana Gabriela, pela amizade e pelos auxílios prestados.

À CAPES, pela bolsa de estudos concedida.

Às bibliotecárias Eliana e Kátia, pela revisão das referências.

Aos funcionários da biblioteca da ESALQ, especialmente ao João, Paulo, Sílvio, Fátima e Silvana, pelos auxílios prestados.

A todas as pessoas que me ajudaram nas coletas, especialmente ao Engenheiro Agrônomo André Luís Lourenção.

Às minhas amigas Aline, Anabel, Ardabil, Ariane, Cláudia, Didi, Maria Regina, Márcia, Maria Cristina, Míriam, Mônica e Vera, pelo carinho e incentivo. 


\section{SUMÁRIO}

LISTA DE FIGURAS E TABELA $\ldots \ldots \ldots \ldots \ldots$ vi RESUMO $\ldots \ldots \ldots \ldots \ldots \ldots \ldots \ldots \ldots \ldots \ldots \ldots \ldots \ldots$ viii

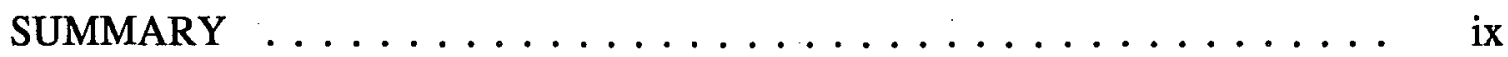

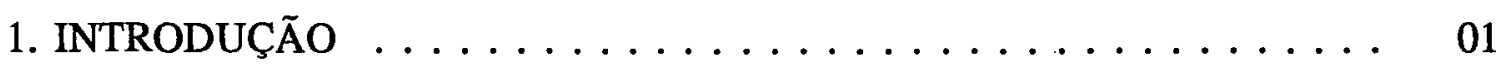

2. REVISÃO DE LITERATURA $\ldots \ldots \ldots \ldots \ldots \ldots \ldots \ldots \ldots \ldots$

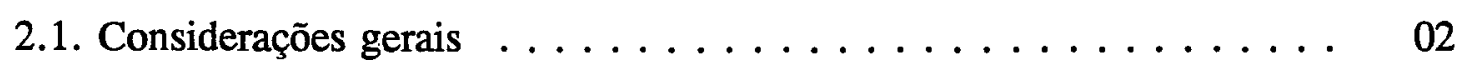

2.2. Distribuição e origem $\ldots \ldots \ldots \ldots \ldots \ldots \ldots \ldots \ldots \ldots$

2.3. Hábito alimentar e plantas hospedeiras $\ldots \ldots \ldots \ldots \ldots \ldots$

2.4. Ação dos tripes $\ldots \ldots \ldots \ldots \ldots \ldots \ldots \ldots \ldots$

2.5. Inimigos naturais $\ldots \ldots \ldots \ldots \ldots \ldots \ldots \ldots \ldots$

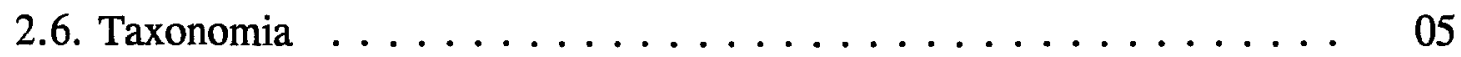

3. METODOLOGIA ....................... 12

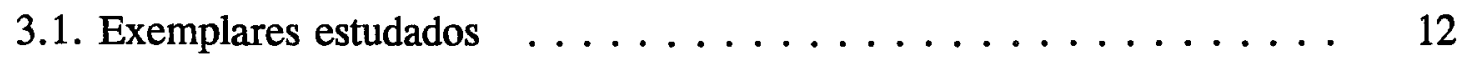

3.2. Coleta dos exemplares $\ldots \ldots \ldots \ldots \ldots \ldots \ldots \ldots \ldots \ldots$

3.3. Preparo para identificação $\ldots \ldots \ldots \ldots \ldots \ldots \ldots \ldots$

3.3.1. "Maceração" dos exemplares . . . . . . . . . . 13

3.3.2. Desidratação dos exemplares $\ldots \ldots \ldots \ldots \ldots \ldots . \ldots 14$

3.3.3. Montagem das lâminas de microscopia $\ldots \ldots \ldots \ldots \ldots$

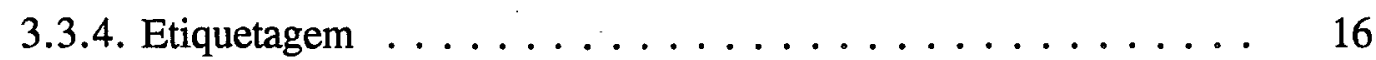

3.4. Identificação $\ldots \ldots \ldots \ldots \ldots \ldots \ldots \ldots \ldots \ldots \ldots \ldots \ldots \ldots \ldots \ldots$

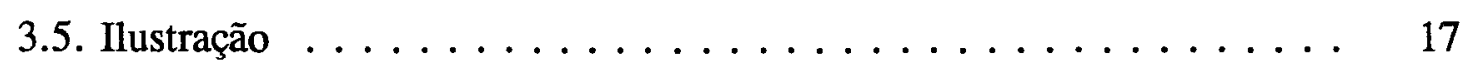

3.6. Terminologia $\ldots \ldots \ldots \ldots \ldots \ldots \ldots \ldots \ldots \ldots \ldots$

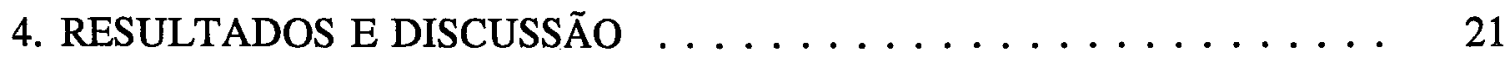

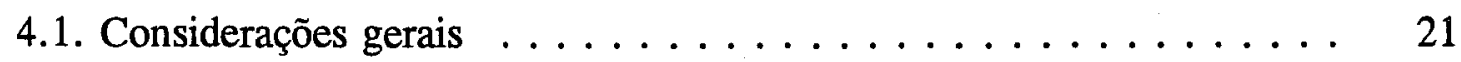

4.2. Chaves para identificação $\ldots \ldots \ldots \ldots \ldots \ldots \ldots \ldots$

4.2.1. Chave para as subordens de Thysanoptera . . . . . . 23

4.2.2. Chave para as famílias mais comuns de Terebrantia . . . . 23

4.2.3. Chave para as subfamílias de Thripidae ... . . . . 24 
4.2.4. Chave para os gêneros e espécies de Panchaetothripinae coletados . . . . . . . . . . . . . . . . . . 24

4.2.5. Chave para os gêneros e espécies de Thripinae coletados $\ldots 25$

4.3. Caracterização das espécies de Thysanoptera coletadas . . . . . 27

4.3.1. Caliothrips phaseoli (Hood, 1912) . . . . . . . . 27

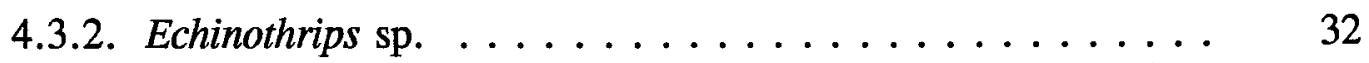

4.3.3. Enneothrips flavens Moulton, 1941 . . . . . . . . . . 34

4.3.4. Frankliniella brevicaulis Hood, 1937 . . . . . . . . 37

4.3.5. Frankliniella gemina Bagnall, 1919 . . . . . . . . . 41

4.3.6. Frankliniella insularis (Franklin, 1908) . . . . . . . . 44

4.3.7. Frankliniella occidentalis (Pergande, 1895) . . . . . . . 46

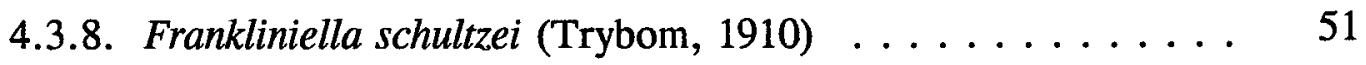

4.3.9. Heliothrips haemorrhoidalis (Bouché, 1833) . . . . . . 55

4.3.10. Palleucothrips musae Hood, $1956 \ldots \ldots \ldots$. . . . . . 57

4.3.11. Selenothrips rubrocinctus (Giard, 1913) . . . . . . . . 61

4.3.12. Stenchaetothrips minutus (Deventer, 1906) . . . . . . . 63

4.3.13. Thrips palmi Karny, 1925 . . . . . . . . . . . . 67

4.3.14. Thrips tabaci Lindeman, $1888 \ldots \ldots \ldots \ldots \ldots \ldots$

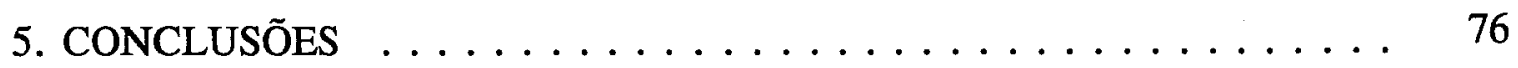

REFERÊNCIAS BIBLIOGRÁFICAS $\ldots \ldots \ldots \ldots \ldots \ldots \ldots$ 


\section{LISTA DE FIGURAS E TABELA}

FIGURA N ${ }^{\circ}$

PÁGINA

01 Morfologia de Thysanoptera (Terebrantia) (adaptado de PALMER et al.,

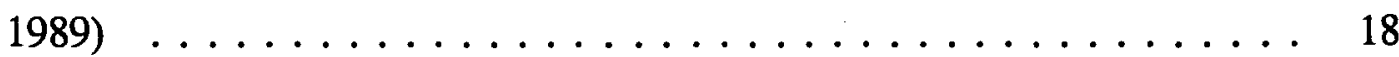

02 Caliothrips phaseoli. A. cabeça (dorsal); B. pronoto; C. metanoto; D.

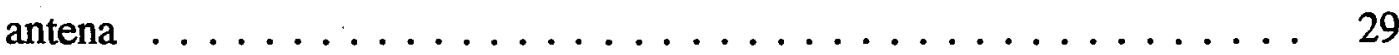

03 Caliothrips phaseoli. A. pleurotergito abdominal V; B. tergitos abdominais VIII-XI ......................... 30

04 Echinothrips sp. A. cabeça (dorsal); B. pronoto; C. metanoto; D. antena 33

05 Enneothrips flavens. A. cabeça (dorsal); B. pronoto; C. metanoto; D. antena; E. esternitos abdominais II e III do $\delta$ : área glandular . . . . . . 36

06 Frankliniella brevicaulis. A. cabeça (dorsal); B. pronoto; C. metanoto; D. antena (em destaque, detalhe do pedicelo do segmento III) . . . . . . . .

07 Frankliniella brevicaulis. A. tergito abdominal VIII; B. tergito abdominal

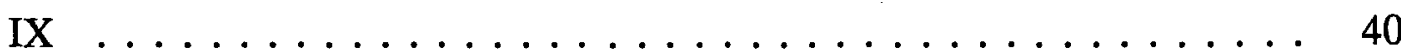

08 Frankliniella gemina. A. cabeça (dorsal); B. pronoto; C. metanoto; D.

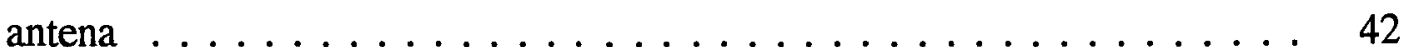

09 Frankliniella gemina. A. tergito abdominal VIII; B. tergito abdominal IX 43

10 Frankliniella insularis. A. cabeça (dorsal); B. pronoto . . . . . . . . 45

11 Frankliniella insularis. A. metanoto; B. tergito abdominal VIII; C. tergito

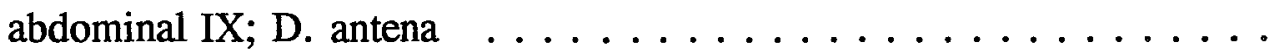

12 Frankliniella occidentalis. A. cabeça (dorsal); B. pronoto; C. metanoto; D.

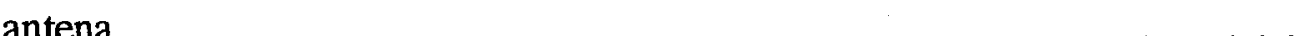

13 Frankliniella occidentalis. A. tergito abdominal VIII; B. tergito abdominal

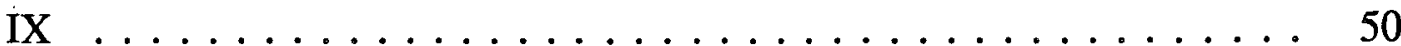

14 Frankliniella schultzei. A. cabeça (dorsal); B. pronoto; C. metanoto; D. antena 
15 Frankliniella schultzei. A. tergito abdominal VIII; B. tergito abdominal IX 54

16 Heliothrips haemorrhoidalis. A. cabeça (dorsal); B. pronoto; C. antena . 56

17 Heliothrips haemorrhoidalis. A. meso e metanoto; B. metanoto . . . . 58

18 Palleucothrips musae. A. cabeca (dorsal); B. pronoto; C. metanoto; D.

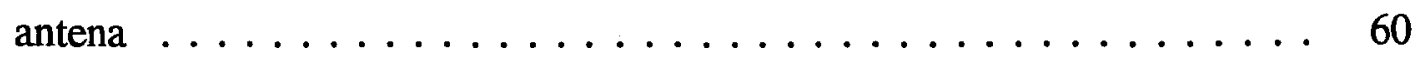

19 Selenothrips rubrocinctus. A. cabeça (dorsal); B. pronoto; C. metanoto: D. antena ........................ 62

20 Selenothrips rubrocinctus. Tergitos abdominais VIII-XI $\ldots \ldots \ldots \ldots 64$

21 Stenchaetothrips minutus. A. cabeça; B. pronoto; C. metanato; D. antena 66

22 Thrips palmi. A. cabeça (dorsal); B. pronoto; C. metanoto; D. antena . 68

23 Thrips palmi. A. pleurotergito abdominal II; B. tergito abdominal VIII; C. tergito abdominal IX ............... 70

24 Thrips tabaci. A. cabeça (dorsal); B. pronoto; C. metanoto; D. antena . 73

25 Thrips tabaci. A. pleurotergito abdominal II; B. tergito abdominal VIII; C. tergito abdominal $\mathrm{IX} \ldots \ldots \ldots \ldots \ldots \ldots \ldots \ldots$

TABELA N ${ }^{\circ}$

01 Espécies e número de tripes nas respectivas plantas hospedeiras . . . . 22 


\title{
ESPÉCIES DE TRIPES (THYSANOPTERA, THRIPIDAE) \\ ASSOCIADAS A ALGUMAS CULTURAS NO BRASIL
}

\author{
Autor: Renata Chiarini Monteiro \\ Orientador: Prof ${ }^{\circ}$ Dr. Roberto A. Zucchi
}

\section{RESUMO}

O estudo consistiu da identificação de espécies de tripes da família Thripidae (Thysanoptera), coletadas em dezenove espécies de plantas, principalmente no Estado de São Paulo. Foram examinados 767 exemplares e quatorze espécies foram identificadas: Caliothrips phaseoli (Hood, 1912); Echinothrips sp.; Enneothrips flavens Moulton, 1941; Frankliniella brevicaulis Hood, 1937; F. gemina Bagnall, 1919; F. insularis (Franklin, 1908); F. occidentalis (Pergande, 1895); F. schultzei (Trybom, 1910); Heliothrips haemorrhoidalis (Bouché, 1833); Palleucothrips musae (Hood, 1956); Selenothrips rubrocinctus (Giard, 1913); Stenchaetothrips minutus (Deventer, 1906); Thrips palmi Karny, 1925 e T. tabaci Lindeman, 1888. E. flavens é a única espécie freqüentemente encontrada em amendoinzeiro Arachis hypogea. T. tabaci é comum em liliáceas e não foi encontrado em algodoeiro Gossypium hirsutum. F. schultzei foi encontrado em algodoeiro. $T$. palmi e $F$. occidentalis são registrados pela primeira vez no Brasil. Chave dicotômica e ilustração de algumas características morfológicas são apresentadas, para auxiliar a identificação dessas espécies. Com esse estudo, inicia-se uma coleção de tripes, em lâmina de microscopia, no Departamento de Entomologia ESALQ/USP, Brasil. 


\title{
THRIPS SPECIES (THYSANOPTERA, THRIPIDAE) ASSOCIATED WITH SOME CROPS IN BRAZIL
}

\author{
Author: Renata Chiarini Monteiro \\ Adviser: Prof. Dr. Roberto A. Zucchi
}

\section{SUMMARY}

This work was carried out to identify thrips species of the family Thripidae (Thysanoptera) collected from nineteen plant species, mainly from the State of São Paulo, Brazil. Samples of 767 thrips specimens were examined, and fourteen species were identified: Caliothrips phaseoli (Hood, 1912); Echinothrips sp.; Enneothrips flavens Moulton, 1941; Frankliniella brevicaulis Hood, 1937; F. gemina Bagnall, 1919; F. insularis (Franklin, 1908); F. occidentalis (Pergande, 1895); F. schultzei (Trybom, 1910); Heliothrips haemorrhoidalis (Bouché, 1833); Palleucothrips musae (Hood, 1956); Selenothrips rubrocinctus (Giard, 1913); Stenchaetothrips minutus (Deventer, 1906); Thrips palmi Karny, 1925 e T. tabaci Lindeman, 1888. E. flavens is the only species frequently found on peanut Arachis hypogea. T. tabaci is common in Liliaceae and it wasn't found on cotton Gossypium hirsutum. F. schultzei was found on cotton. T. palmi and F. occidentalis are recorded for the first time in Brazil. A dichotomic key and illustrations of some morphological characters for each species are presented. As a result of this research, a thrips collection in microscope slides is being organized at the Department of Entomology - ESALQ/USP, Brazil. 


\section{INTRODUÇÃO}

Os tripes (ordem Thysanoptera) são insetos pequenos (1 a $14 \mathrm{~mm}$ ), pouco estudados não apenas por taxonomistas, mas também por pesquisadores de outras áreas (apenas 2\% dos entomologistas se dedicam ao estudo de tripes) (LEWIS, 1991). Provavelmente, os escassos estudos com tripes estejam relacionados à dificuldade em coletá-los e, principalmente, em prepará-los para estudos microscópicos. Além disso, a identificação taxonômica é complexa.

Do ponto de vista agrícola, os tripes são importantes por ocasionarem danos diretos e indiretos (transmissão de agentes fitopatogênicos) às culturas.

A ordem Thysanoptera é dividida em duas subordens, Terebrantia e Tubulifera. A classificação nessas subordens e suas famílias é relativamente fácil, por serem os caracteres bem definidos e de fácil visualização. No entanto, a identificação de gêneros e espécies é mais problemática.

No Brasil, poucos foram os trabalhos feitos sobre a identificação de tripes e há muito a ser estudado. De um modo geral, os tripes têm sido identificados, nos estudos de entomologia agrícola, com base nas citações da literatura ou no hospedeiro, o que muitas vezes leva a erros. A correta identificação é a base de todos os demais estudos, uma vez que é a chave para o armazenamento e comunicação de todas as informações conhecidas a respeito de um organismo particular.

Este estudo teve por objetivos a identificação de algumas espécies de Thysanoptera da família Thripidae e o estabelecimento de possíveis associações entre tais espécies e as culturas. 


\section{REVISÃO DE LITERATURA}

\subsection{Considerações gerais}

Os tripes podem medir de 1 a $14 \mathrm{~mm}$ (LEWIS, 1973). Entretanto, as espécies de importância agrícola medem ao redor de $1,5 \mathrm{~mm}$ de comprimento.

Os tripes caracterizam-se por suas peças bucais únicas e assimétricas, que consistem essencialmente de uma única mandíbula (esquerda), dois estiletes maxilares e labro (LEWIS, 1973, 1991). Além desta característica, duas outras são únicas da ordem: a presença de um arólio vesiculiforme adesivo e eversível, na extremidade tarsal, e uma metamorfose intermediária entre a simples e a completa (remetabolia) (KONO \& PAPP, 1977).

As asas, quando presentes, também são distintas, com venação reduzida e uma franja de longos cílios; porém, não são únicas entre os insetos, uma vez que asas franjadas também são encontradas em alguns representantes das ordens Coleoptera, Lepidoptera e Hymenoptera (KONO \& PAPP, 1977; LEWIS, 1973, 1991).

\subsection{Distribuição e origem}

Os tripes estão dispersos no mundo todo, havendo uma predominância de espécies nas regiões tropicais. No entanto, há muitas espécies nas regiões temperadas e poucas, nas regiões árticas (LEWIS, 1973).

Os insetos da ordem Thysanoptera parecem ter evoluído dos mesmos ancestrais dos Hemiptera, Psocoptera e Phthiraptera (MOUND, 1993). 


\subsection{Hábito alimentar e plantas hospedeiras}

São, principalmente, insetos fitófagos, micófagos ou predadores. Sua diversidade adaptativa os têm capacitado a explorar, com sucesso, diversos nichos, não apenas as mais diferentes plantas, mas também habitats infestados por fungos, tais como a serrapilheira e a casca de árvores vivas e mortas (LEWIS, 1973; ANANTHAKRISHNAN, 1993).

Nos últimos anos, muitos tripes fitófagos têm adquirido a condição de praga. Como são oportunistas ideais, o desenvolvimento de grandes populações pode ser estimulado por uma monocultura da planta hospedeira e por seu manejo (MOUND, 1993). Muitas espécies são polífagas e, freqüentemente, são essas as que causam problemas aos agricultores, multiplicando-se na vegetação ao redor da cultura ou mantendo sua população em plantas daninhas, deixadas nos campos entre culturas sucessivas, ou em plantas utilizadas em rotação de cultura (PALMER, 1990).

Segundo LEWIS (1991), devido a um trabalho sobre tripes de Wardle \& Simpson, publicado em 1927, acreditava-se que os tripes raspavam o tecido foliar. No entanto, técnicas mais sofisticadas permitiram visualizar que, na verdade, os tripes perfuram o tecido e sugam o conteúdo líquido que dele extravasa.

O mecanismo de alimentação consiste em fazer um buraco na epiderme com a única mandíbula, perfurando as células subepidermais com os estiletes maxilares e succionando o conteúdo líquido, que extravasa das células perfuradas, para dentro do cone bucal intimamente a elas aplicado (KONO \& PAPP, 1977).

A alimentação dos tripes em plantas tem, como conseqüência da extração do conteúdo celular, a formação de áreas descoradas e o aparecimento, nos locais atacados, de pontos ferruginosos (necrose dos tecidos) ou pardo-enegrecidos (deposição de gotas fecais). Ainda que os tripes presentes nas flores possam ser, até certo ponto, benéficos, auxiliando na polinização, muitas vezes eles as danificam, esterilizando-as e impedindo a formação de frutos (LIMA, 1938).

Quando os tripes se alimentam em tecidos vegetais em desenvolvimento, as células afetadas não crescem normalmente. Assim, as folhas e pétalas tornam-se 
distorcidas após um subseqüente crescimento das células não afetadas. A alimentação em tecidos desenvolvidos faz com que as células tornem-se cheias de ar, o que dá uma aparência prateada ao tecido afetado (JAGER \& BUTÔT, 1993).

\subsection{Ação dos tripes}

Os tripes podem atingir o homem direta ou indiretamente. No primeiro caso, irritando a pele e ativando alarmes de incêndio, fatos comuns na Europa, quando o nível populacional de tripes é muito elevado. No segundo caso, danificando as culturas ou, pelo contrário, beneficiando-as, como agentes polinizadores ou de controle biológico de pequenos artrópodes (outros tripes, ácaros, moscas brancas, coccídeos) e de certas espécies de plantas daninhas (LEWIS, 1973, 1991).

Os tripes fitófagos se alimentam nas mais diversas partes da planta, exceto nas raízes e, geralmente, concentram-se em tecidos de crescimento rápido, tais como folhas novas, flores e brotos terminais (LEWIS, 1973).

Os tripes podem afetar desfavoravelmente as plantas através do dano direto de alimentação (incluindo a formação de galhas, induzidas pela toxina da saliva) ou através da introdução de agentes fitopatogênicos, principalmente partículas de vírus, notadamente o "Tomato Spotted Wilt Virus" (TSWV). Há, também, aqueles que são vetores mecânicos de esporos e bactérias causadores de doenças (AMIN et al., 1980; LEWIS, 1973).

Há poucas espécies vetoras de vírus. No entanto, elas são comuns e todas pertencem à família Thripidae. Segundo FUNDERBURK (1993), sete espécies de tripes transmitem o TSWV, entre as quais estão citadas: Frankliniella schultzei (Trybom, 1910), Frankliniella occidentalis (Pergande, 1895), Thrips palmi Karny, 1925 e Thrips tabaci Lindeman, 1888. WIJKAMP et al. (1993) relataram a existência de oito espécies vetoras desse vírus, das quais $F$. occidentalis é, aparentemente, a mais importante. Apenas a ninfa de tripes pode adquirir o TSWV, enquanto tanto a ninfa como o adulto podem transmiti-lo (LEWIS, 1973; FUNDERBURK, 1993). No entanto, há um período de incubação, variável para cada espécie de tripes, para que a ninfa se 
torne infectiva (Sakimura ${ }^{1}$ citado por SAKIMURA, 1963).

Muitas espécies de tripes foram relatadas por transmitir o "Tobacco Ringspot Virus" (TRSV) (BERGESON et al., 1964), sendo confirmada a transmissão apenas por T. tabaci (MESSIEHA, 1969).

A transmissão mecânica desempenha um importante papel para o "Tobacco Streak Virus" (TSV), que também tem como vetores $T$. tabaci e $F$. occidentalis (KAISER et al., 1982).

\subsection{Inimigos naturais}

Os tripes têm como inimigos naturais predadores e parasitóides. Os predadores encontram-se nas ordens Hemiptera (Anthocoridae e Miridae), Coleoptera (Coccinellidae, Staphilinidae e Melyridae), Neuroptera (Chrysopidae), Thysanoptera (Aeolothripidae e Phlaeothripidae), Hymenoptera (Sphecidae) e Diptera (Syrphidae, Cecidomyiidae e Asilidae). Além dos insetos, os ácaros (Phytoseiidae e Pyemotidae) também predam tripes (Phytoseiidae e Pyemotidae). Os principais parasitóides pertencem a ordem Hymenoptera (Eulophidae, Trichogrammatidae e Mymaridae). Nematóides (Allantonematidae) e fungos podem parasitar tripes, causando degeneração do ovário e infecções, respectivamente (ANANTHAKRISHNAN, 1993; LEWIS, 1973; LIMA, 1938; Mound ${ }^{2}$ ).

\subsection{Taxonomia}

Poucos entomologistas se dedicaram ao estudo dos Thysanoptera. A despeito disto, houve um avanço nos estudos taxonômicos na primeira metade do século

${ }^{1}$ SAKIMURA, K. The present status of thrips-borne viruses. In: K. MARAMO$\mathrm{ROSCH}$, ed. Biological transmission of disease agents, New York, Academic Press, 1962. p. 33-40.

${ }^{2}$ MOUND, L.A. (The Natural History Museum. London, UK) Comunicação pessoal, 1994. 
XIX, devido à importância adquirida pelos tripes e ao enorme progresso feito pelos poucos especialistas, elevando a importância da ordem (LEWIS, 1973).

A ordem Thysanoptera é dividida em duas subordens, Terebrantia e Tubulifera, caracterizadas, principalmente, pela presença ou ausência de um ovipositor externo, respectivamente.

Atualmente, oito famílias são reconhecidas em Thysanoptera (Mound $e t$ $a l .^{3}$ citados por PALMER et al., 1989), sendo sete pertencentes à Terebrantia (Aeolothripidae, Merothripidae, Heterothripidae, Thripidae, Uzelothripidae, Fauriellidae e Adiheterothripidae) e apenas uma, à Tubulifera (Phlaeothripidae) (PALMER, 1990).

As famílias mais comuns de Terebrantia (Aeolothripidae, Merothripidae, Heterothripidae e Thripidae) são facilmente reconhecidas com base, principalmente, no ovipositor e nos sensilos das antenas. As fêmeas de Aeolothripidae possuem o ovipositor curvado para cima e as asas anteriores largas e com o ápice arredondado. As outras três famílias diferem em ter o ovipositor curvado para baixo e as asas anteriores estreitas, com o ápice pontiagudo. O tipo de sensilo nos segmentos antenais III e IV é utilizado para separar estas três famílias. Em Merothripidae, além do ovipositor ser pouco desenvolvido, os sensilos são como tímpanos e circundam parcialmente a extremidade dos segmentos antenais III e IV. Heterothripidae e Thripidae apresentam o ovipositor bem desenvolvido. Em Heterothripidae, as áreas sensoriais são estreitas, compostas de muitos sensilos pequenos e circulares, que circundam a extremidade dos segmentos antenais III e IV. Em Thripidae, os sensilos são estruturas simples ou furcadas, conhecidas como tricomas sensoriais (KONO \& PAPP, 1977; PALMER et al., 1989).

As duas maiores famílias de tripes são Thripidae e Phlaeothripidae. A maioria das espécies bem conhecidas de pragas pertence à primeira família. A segunda família inclui muitas espécies pragas, como também algumas espécies utilizadas no controle biológico de plantas daninhas e algumas espécies predadoras, além de uma grande

${ }^{3}$ MOUND, L.A.; HEMING, B.S.; PALMER, J.M. Phylogenetic relationships between the families of recent Thysanoptera (Insecta). Zoological Journal of the Linnean Society of London, London, 69: 111-41, 1980. 
diversidade de espécies fungívoras (MOUND, 1993).

A família Thripidae possui cerca de 1500 espécies e 250 gêneros conhecidos. Seus representantes vivem, geralmente, em flores e folhas; muitos estão associados à gramíneas e poucos são predadores. É dividida em duas subfamílias (Panchaetothripinae e Thripinae). A subfamília Panchaetothripinae já se chamou Heliothripinae. Possui aproximadamente 110 espécies, em 33 gêneros conhecidos, e seus representantes se alimentam de folhas maduras de plantas superiores. A subfamília Thripinae tem cerca de 1400 espécies, em 220 gêneros amplamente distribuídos. Inclui a maioria das espécies pragas, assim como a maioria das espécies que habitam as flores (MOUND et al., 1993).

Os Merothripidae são fungívoros e a maioria das espécies é neotropical. Os Heterothripidae também são neotropicais, mas todos vivem em flores. Pouco se sabe sobre sua biologia e, embora estejam grandemente dispersos, raramente são coletados. A família Aeolothripidae é a mais conhecida, com muitas espécies na região ártica, mas uma grande diversidade de gêneros na América do Sul e Austrália. Tais espécies são, geralmente, predadoras de pequenos artrópodes, embora muitas delas também se alimentem de pólen e outros tecidos florais (MOUND \& HEMING, 1991).

A identificação de gêneros e espécies é mais difícil. Poucos tripes são facilmente identificados devido a estruturas únicas ou especificidade hospedeira (PALMER et al., 1991).

Estima-se que há entre quatro mil (REED, 1977) e cinco mil (LEWIS, 1973, 1991) espécies de tripes descritas no mundo e, provavelmente, outras cinco mil, principalmente nos trópicos, ainda por serem descritas (LEWIS, 1991). GASTON \& MOUND (1993) referem-se a um total de 6479 nomes específicos na ordem Thysanoptera, dos quais 5062 são atualmente aceitos, por haver $22 \%$ de sinonímia.

Karny ${ }^{4}$ citado por PRIESNER (1949a) publicou, pela primeira vez, uma chave para identificação dos gêneros de Thysanoptera. PRIESNER (1949a) fez

\footnotetext{
${ }^{4}$ KARNY, H. Zur Systematik der Orthopteroiden Insekten, Thysanoptera. Treubia, Batavia, 1: 211-69, 1921.
} 
acréscimos e alterações à chave de Karny, de acordo com os conhecimentos adquiridos e revisados até então, e publicou "Genera Thysanopterorum".

JACOT-GUILLARMOD (1970-1979) completou seis partes do "Catalogue of the Thysanoptera of the World" antes de sua morte, em 1979. Brothers reuniu as referências registradas e não publicadas por Jacot-Guillarmod na sétima parte da série (JACOT-GUILLARMOD \& BROTHERS, 1986).

Os Thysanoptera da América do Sul foram relacionados numa série de cinco trabalhos, onde foram listadas e descritas, além das espécies de importância econômica comumente conhecidas, muitas espécies novas (MOULTON, 1932; 1933a,b,c,d).

HOOD (1935) descreveu várias espécies e um gênero novo da região neotropical, além de apresentar ilustrações de três espécies inadequadamente descritas anteriormente.

Estudos taxonômicos sobre os tripes neotropicais assinalados no Peru, incluindo duas espécies encontradas no Brasil, uma espécie de Trinidad e uma do Panamá, foram publicados numa série de oito trabalhos intitulados "Studies in Neotropical Thysanoptera" (HOOD, 1936a,b; 1937a,b,c; 1938b,c,d). Ainda a respeito dos tripes de origem neotropical, HOOD (1938a) fez descrições de gêneros e espécies encontrados na Flórida e Carolina do Norte, que alcançaram os Estados Unidos, em sua maioria, através das Antilhas.

Estendendo seus estudos para todo o continente americano, HOOD $(1940 ; 1941 \mathrm{a}, \mathrm{b})$ publicou uma série de três trabalhos denominados "A century of new American Thysanoptera".

Estudos sobre os Thysanoptera encontrados em Minas Gerais, Brasil, foram feitos por MOULTON $(1938,1941)$, onde espécies conhecidas são relacionadas e espécies novas, descritas. HOOD (1960) descreveu espécies novas, coletadas em Santa Catarina, Brasil.

Outros trabalhos envolvendo descrições de gêneros e espécies de tripes do Brasil foram feitos em anos subseqüentes (HOOD, 1949, 1950, 1956), sob o título "Brasilian Thysanoptera", sendo incluídas sinonímias e um índice, em ordem sistemá- 
tica, dos gêneros e espécies. O número de espécies brasileiras listadas excedeu o número total de espécies anteriormente relatadas para todo continente, incluindo o Panamá e Trinidad, na série de trabalhos de Moulton concluída em 1933 e intitulada "The Thysanoptera of South America".

SILVA et al. (1968) compilaram as informações de tripes no Brasil (134 espécies), com os respectivos hospedeiros e distribuição. Das cinco famílias mais comuns da ordem, apenas Merothripidae não foi referida.

Trabalhos relacionados à taxonomia de tripes de importância agrícola foram desenvolvidos por STANNARD (1968), MOUND \& PALMER (1972), REED (1977), MOUND \& WALKER (1982), JOHANSEN (1989a,b), JOHANSEN \& MOJICA (1989) e NAKAHARA (1991a).

Revisões genéricas de algumas espécies.de importância foram realizadas: Frankliniella (HOOD, 1937a; SAKIMURA \& O'NEILL, 1979); Anaphothrips e alguns gêneros relacionados (Bhatti ${ }^{5}$ citado por BHATTI, 1980); Thrips (Bhatti ${ }^{3}$ citado por BHATTI, 1980); Thrips e alguns gêneros relacionados, que se alimentam de capim e cereais (BHATTI \& MOUND, 1980); Chirothrips (HOOD, 1939; PRIESNER, 1949b); Caliothrips (Wilson ${ }^{6}$ citado por NAKAHARA, 1991b); Heterothrips, no México (JOHANSEN, 1989b).

Revisões específicas ou trabalhos de reconhecimento específico também podem ser encontrados, como é o caso de espécies sinonimizadas como Thrips hawaiiensis e Thrips florum (NAKAHARA, 1985b) e ainda um grupo intermediário, Thrips exilicornis (PALMER \& WETTON, 1987); Sericothrips e espécies norteamericanas relacionadas (NAKAHARA, 1988a) e espécies de Scirtothrips (MOUND \& PALMER, 1981).

\footnotetext{
${ }^{5}$ BHATTI, J.S. A preliminary revision of Taeniothrips. Oriental Insects, Delhi, 12(2): 157-99, 1978.

${ }^{6}$ WILSON, T.H. A monograph of the subfamily Panchaetothripina (Thysanoptera: Thripidae). Gainesville, American Entomological Institute, 1975. 354p. (Memoirs of the American Entomological Institute, 23).
} 
HOOD (1925) descreveu novas espécies do gênero Frankliniella e apresentou os quatro grupos em que o gênero se divide (tritici, cephalica, intonsa e minuta). Mais adiante, HOOD (1937a) ressaltou a importância de outras características (todas sobre a quetotaxia) na definição de espécies do gênero Frankliniella. MOULTON (1948) discorreu sobre o gênero Frankliniella, apresentando chaves para a determinação de grupos, séries e espécies e um índice de espécies, variedades e formas. SAKIMURA \& O'NEILL (1979) redefiniram o gênero Frankliniella e revisaram as espécies do grupo minuta. No entanto, apesar de o gênero Frankliniella ser bem caracterizado, suas espécies são, freqüentemente, difíceis de serem distinguidas umas das outras, devido à homogeneidade de detalhes estruturais (MOUND \& NAKAHARA, 1993).

O gênero Thrips é o mais antigo da ordem Thysanoptera e um dos que apresentam grande especiação em muitas partes do mundo. Inclui muitas espécies de importância econômica. JACOT-GUILLARMOD (1975) catalogou 210 espécies de Thrips no mundo todo. O número de espécies catalogadas aumentou quando espécies costumeiramente incluídas no gênero Taeniothrips foram consideradas no gênero Thrips (Bhatti ${ }^{7}$ citado por BHATTI, 1980). MOUND \& NAKAHARA (1993) referem-se à existência de quase 300 espécies de Thrips, que apresentam uma grande diversidade de detalhes estruturais. As espécies de Thrips da Índia foram revisadas e uma chave, para as 33 espécies válidas, incluindo oito espécies novas e uma subespécie nova, foi apresentada (BHATTI, 1980).

Algumas espécies causam danos de alimentação típicos, sendo possível identificá-las associando-as à cultura e ao local (AMIN \& PALMER, 1985).

A despeito das chaves serem feitas para adultos de tripes e, geralmente, para as fêmeas, KIRK (1987) elaborou uma chave para ninfas de algumas espécies.

As estruturas utilizadas na classificação dos Thysanoptera foram discutidas por PALMER et al. (1989) e NAKAHARA (1991a).

Atualmente, os estudos sobre Thysanoptera têm alcançado detalhes

${ }^{7}$ BHATTI, J.A. A preliminary revision of Taeniothrips. Oriental Insects, Delhi, 12(2): 157-99, 1978. 
bastante complexos. NAKAHARA (1988b) fez um estudo preliminar sobre a pigmentação facetal dos olhos compostos de Terebrantia.

No Brasil, as espécies de tripes associadas ao feijoeiro e à soja foram relacionadas por ROSSETO et al. (1974) e ALMEIDA et al. (1994), respectivamente. 


\section{METODOLOGIA}

A pesquisa foi desenvolvida no laboratório de taxonomia do Departamento de Entomologia da ESALQ/USP, sob orientação do Prof ${ }^{\circ}$ Dr. Roberto Antonio Zucchi e colaboração do Dr. Laurence A. Mound, do " The Natural History Museum", em Londres.

\subsection{Exemplares estudados}

Foi feita a caracterização das espécies coletadas, através de uma discussão sucinta, com posterior comentário. Os dados relativos ao material examinado foram listados de acordo com PAPAVERO (1983). O local onde foram depositadas as preparações microscópicas está representado pelas siglas:

- ESALQ: Escola Superior de Agricultura "Luiz de Queiroz";

- BMNH: British Museum (Natural History);

- IBUNAM: Instituto de Biología, Universidad Nacional Autónoma de México.

\subsection{Coleta dos exemplares}

Os exemplares foram obtidos em coletas ocasionais.

A metodologia de coleta foi baseada em LEWIS (1973) e PALMER $e t$ al.(1989).

Meio preservante: a maioria das amostras de tripes foi coletada em AGA, que consiste 
em uma mistura de 10 partes de álcool etílico 60\%, 1 parte de glicerina e 1 parte de ácido acético glacial (PALMER et al., 1989). O AGA é o meio mais indicado para a coleta, uma vez que preserva a flexibilidade dos espécimens. No entanto, a coleta pode também ser feita em álcool etílico $60 \%$.

Método de coleta: a coleta foi feita na planta e a transferência dos exemplares, para os frascos contendo o meio preservante, foi realizada no local onde se encontrava a planta (campo ou casa-de-vegetação) ou no laboratório. Neste caso, acondicionou-se, em sacos de papel, as partes das plantas contendo tripes, até a chegada ao laboratório. A transferência dos espécimens para os frascos, contendo o meio de coleta, foi feito por meio de um pincel de cerdas finas e macias.

Locais de coleta: os exemplares foram coletados em dois municípios do Estado de São Paulo (Piracicaba e Campinas). Além dessas coletas, foram recebidos, para identificação, exemplares coletados em vinte municípios do Estado de São Paulo (Atibaia, Botucatu, Campinas, Holambra, Itha Solteira, Itapetininga, Itapira, Jaboticabal, Jaguariúna, Mogi-Mirim, Paranapanema, Paulínia, Piedade, Pinhalzinho, Piracicaba, Rafard, Registro, São Miguel Arcanjo, Sete Barras e um município desconhecido), um de Minas Gerais (Carmo do Rio Claro), dois do Paraná (Bandeirantes e Londrina), dois do Mato Grosso do Sul (Taquaruçu e Três Lagoas) e um da Bahia (Jequié).

\subsection{Preparo para identificação}

A metodologia de preparo foi baseada em LEWIS (1973) e PALMER et al. (1989), consistindo das seguintes etapas a seguir relacionadas.

\subsection{1. "Maceração" dos exemplares}

Visa a eliminação do conteúdo corporal, possibilitando uma melhor visualização das características morfológicas a serem examinadas. Infelizmente, esse 
processo afeta a coloração do corpo e, assim, quando muitos exemplares forem coletados, alguns não devem ser macerados.

Foram seguidos os passos abaixo:

1. Cerca de 20 indivíduos foram retirados dos frascos de coleta e transferidos, com auxílio de estiletes metálicos muito finos (feitos com alfinete entomológico 00), para um vidro de relógio contendo AGA; em seguida, foram transferidos para outro vidro de relógio contendo álcool $60 \%$ e armazenados por, pelo menos, 24 horas;

2. transferidos do álcool $60 \%$ para $\mathrm{NaOH} 5 \%$; espécimens claros deixados por $1 / 2$ a 1 hora; espécimens maiores ou mais escuros, por mais de 4 horas; o período exato somente pôde ser determinado pela experiência, mas foi o mais curto possível para minimizar danos. Durante este período:

a. o abdome foi perfurado entre as coxas posteriores com um estilete muito fino de metal e, em seguida, o espécimen foi levemente massageado, para que a maioria dos conteúdos do corpo fosse expelida, e,

b. as pernas e antenas foram distendidas, mas não as asas, até um pouco antes da $\mathrm{NaOH}$ ser removida;

3. transferidos da $\mathrm{NaOH}$ para um pouco de água destilada e, gradualmente, foi adicionado álcool 50\%; e

4. transferidos para álcool $60 \%$ e armazenados por, pelo menos, 24 horas;

\subsubsection{Desidratação dos exemplares}

1. Transferidos do álcool $60 \%$ para o álcool $70 \%$, onde permaneceram por 1 hora; as pernas, as antenas e as asas foram distendidas;

2. do álcool $70 \%$ para o álcool $80 \%$ (20 minutos);

3. do álcool $80 \%$ para o álcool $90 \%$ (10 minutos);

4. do álcool $90 \%$ para o álcool $96 \%$ (5 minutos);

5. do álcool $96 \%$ para o álcool $96 \%$ novo (5 minutos); e

6. do álcool $96 \%$ para o óleo de cravo (1/2 a 1 hora antes da montagem). 


\subsubsection{Montagem das lâminas de microscopia}

A importância e a dificuldade na montagem das lâminas foram discutidas por MOUND \& PITKIN (1972).

A montagem das lâminas foi feita em microscópio estereoscópico, utilizando-se estiletes finos de metal.

O meio indicado para montagens definitivas é o bálsamo-do-canadá. No entanto, esse meio, além de apresentar uma maior dificuldade na manipulação dos espécimens, é de alto custo e acarreta dificuldades na lavagem das lâminas. Assim, por conveniência, foi utilizado o Hoyer e, visando-se contornar os problemas relacionados à higroscopicidade apresentados pelo mesmo, foi feita a lutagem das lâminas com Verniz 2001 Red Enamel ${ }^{\circledR}$.

As seguintes etapas foram seguidas:

1. Uma lamínula limpa foi colocada sobre o bloco de montagem; uma gota de Hoyer foi colocada sobre o centro da lamínula e, neste local, um espécimen de tripes foi colocado com o lado ventral para cima; a quantidade de meio (Hoyer ou bálsamo) deve ser suficiente, após secagem, para suportar a lamínula sem distorcer o espécimen;

2. As antenas, pernas e as asas foram distendidas, para não esconderem o corpo;

3. Uma pequena gota de Hoyer foi colocada no centro de uma lâmina de microscopia limpa, que foi invertida e abaixada, firme e cuidadosamente, sobre o espécimen no Hoyer sobre a lamínula;

4. Assim que as superfícies se tocaram, voltou-se o conjunto (lâmina + lamínula) à posição normal. Essa técnica evita a formação de bolhas, que estragam as lâminas, e facilita a distensão dos apêndices, principalmente das asas; e

5. As preparações microscópicas foram colocadas em estufa, à cerca de $37^{\circ} \mathrm{C}-40^{\circ} \mathrm{C}$, até a secagem. 


\subsubsection{Etiquetagem}

As etiquetas foram feitas em computador, com o programa "Word Perfect", e impressas a laser.

Cada lâmina recebeu duas etiquetas.

1. A etiqueta do lado direito apresenta a planta hospedeira (nomes comum e científico), local de coleta na planta, o país (em letras maiúsculas), a localidade (cidade e a sigla da Unidade da Federação), a data e o nome do coletor.

2. A etiqueta do lado esquerdo indica o sexo, a forma e, escrito à lápis (grafite), o nome genérico ou específico (com o autor).

\subsection{Identificação}

As identificações de gêneros e de espécies foram baseadas, principalmente, na chave de PALMER et al. (1989). Os seguintes caracteres morfológicos foram, quase sempre, examinados:

\section{Cabeça}

- características gerais: coloração, tamanho, superfície (presença ou ausência de esculturações), formato;

- antenas: número e formato dos antenômeros; tipo de sensilos presentes no III e IV antenômeros;

- ocelos: presença ou ausência;

- cerdas: número, comprimento e posição das cerdas ocelares e pós-oculares;

- palpos maxilares: $\mathrm{n}^{\mathbf{0}}$ de segmentos.

\section{Tórax}

- características gerais: coloração, tamanho, esculturação;

- protórax: forma (trapezoidal ou retangular); cerdas (número, posição e tamanho); 
- pterotórax: mesonoto (furca: formato, presença ou ausência de espínula); metanoto (esculturações, cerdas, sensilos campaniformes e furca - formato e presença ou ausência de espínula);

- pernas: tarsos (número de segmentos);

- asas anteriores: superfície (coberta ou não de microtríquias), nervuras (presença ou ausência; número, disposição, comprimento e formato de cerdas);

\section{Abdome}

- características gerais: coloração, esculturações;

- cerdas: discais, laterais e marginais;

- ovipositor: tamanho e direção (voltado para cima ou para baixo);

- VIII segmento: - ctinídeo: presença ou ausência, posição em relação ao espiráculo; pente póstero-marginal: presença ou ausência e número, formato e disposição dos dentes;

- IX e X segmentos: número de poros;

- Machos: áreas glandulares (presença ou ausência, formato, comprimento e largura).

\subsection{Ilustração}

Os desenhos foram feitos com auxílio de câmara clara acoplada a um microscópio biológico, com aumentos de 50, 100 ou 1000 vezes. Todas as ilustrações são de fêmeas.

A figura, na qual foram assinalados os caracteres morfológicos utilizados na identificação de tripes, foi adaptada de PALMER et al. (1989) (Figura 1).

\subsection{Terminologia}

A terminologia utilizada foi baseada em PALMER et al. (1989) e os 


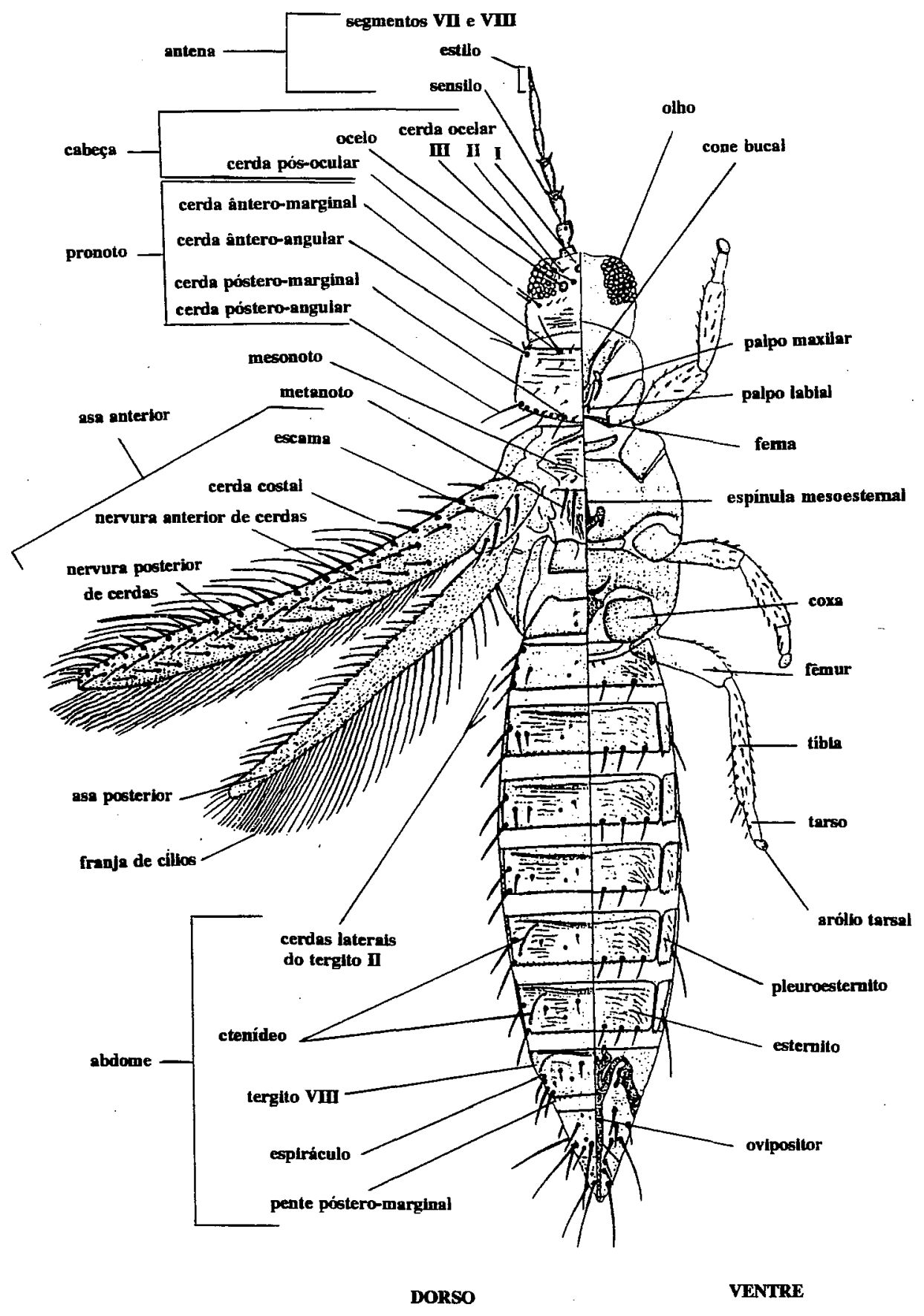

Figura 1. Morfologia de Thysanoptera (Terebrantia) (adaptado de PALMER et al., 1989). 
nomes científicos, em PALMER et al. (1989), STANNARD (1968) e em Mound . $^{8}$

Para facilitar a compreensão dos caracteres morfológicos utilizados nas chaves e na caracterização, foi organizado o glossário abaixo:

Áreas glandulares: áreas de formato, largura e comprimento variáveis, freqüentemente presentes nos esternitos abdominais dos machos.

Cerda: processo destacável, em forma de pêlo ou espinho, com uma cavidade basal.

Cerdas b1, b2 e b3: maiores cerdas posteriores nos tergitos abdominais IX e X, sobre ou próximas às margens posteriores dos esternitos abdominais.

Cerdas discais: cerdas existentes na parte centro-mediana dos tergitos e/ou esternitos abdominais.

Cerdas laterais: 3 ou 4 cerdas sobre ou próximas à margem lateral, em cada lado do tergito abdominal II.

Cerdas medianas: par de cerdas medianas do metanoto.

Cerdas ocelares:

- par I: em frente ao ocelo anterior;

- par II: lateral aos ocelos;

- par III: dentro ou fora do triângulo ocelar; comprimento das cerdas e distância entre suas bases.

${ }^{8}$ MOUND, L.A. (The Natural History Museum. London, UK) Comunicação pessoal, 1994. 
Craspedum: expansão membranosa, nas margens posteriores dos tergitos abdominais.

Crescente ocelar: coloração em forma crescente, que circunda cada ocelo; normalmente são alaranjados ou avermelhados.

Ctenídeo: grupo de microtríquias em formato de arco, que ocorre em par e localiza-se próximo ao espiráculo, em cada um dos lados do VIII tergito abdominal; geralmente também está presente em alguns dos tergitos anteriores ao VIII. Sua posição em relação ao espiráculo do VIII segmento abdominal é variável (ântero-lateral ou póstero-mediana).

Espínula: processo espiniforme, na parte anterior da furca do meso e/ou metatórax.

Estrias: marcas cuticulares.

Furca: apodema localizado no meso e metatórax.

Microtríquia: processo da cutícula pequeno, fino, em formato de agulha ou denteado.

Pente: fileira de cerdas presentes na margem posterior do VIII segmento abdominal, que pode ser completa ou não, com cerdas de comprimento, espessura e base variáveis.

Triângulo ocelar: figura formada pela união dos três ocelos, através de uma linha imaginária, que tangencia o contorno externo dos mesmos.

Tricobótria: cerda sensorial, que se insere em uma área especializada. 


\section{RESULTADOS E DISCUSSÃO}

\subsection{Considerações gerais}

Foram examinados 767 exemplares, coletados em dezenove espécies de plantas, montados em lâminas de microscopia (Tabela 1). Foram identificados nove gêneros e quatorze espécies de tripes, todas da família Thripidae, a seguir relacionadas: Caliothrips phaseoli (Hood, 1912); Echinothrips sp.; Enneothrips flavens Moulton, 1941; Frankliniella brevicaulis Hood, 1937; Frankliniella gemina Bagnall, 1919; Frankliniella insularis (Franklin, 1908); Frankliniella occidentalis (Pergande, 1895), Frankliniella schultzei (Trybom, 1910); Heliothrips haemorrhoidalis (Bouché, 1833); Palleucothrips musae (Hood, 1956); Selenothrips rubrocinctus (Giard, 1913); Stenchaetothrips minutus (Deventer, 1906); Thrips palmi Karny, 1925 e Thrips tabaci Lindeman, 1888.

As preparações microscópicas estão depositadas no Departamento de Entomologia da Escola Superior de Agricultura "Luiz de Queiroz" (ESALQ), no "The Natural History Museum", em Londres e no Instituto de Biología, Universidad Nacional Autónoma de México (IBUNAM), no México.

Com relação ao gênero Frankliniella, foram coletados exemplares cuja identificação da espécie não foi esclarecida. Estes exemplares estão sendo examinados pelo Dr. Laurence A. Mound e Dr. Steve Nakahara. 
Tabela 1. Espécies e número de tripes nas respectivas plantas hospedeiras*.

\begin{tabular}{|c|c|c|}
\hline Espécies & Plantas hospedeiras & $\begin{array}{l}\text { Número de } \\
\text { exemplares }\end{array}$ \\
\hline Caliothrips phaseoli & feijoeiro, girassol e soja & 106 \\
\hline Echinothrips sp. & soja & 17 \\
\hline Enneothrips flavens & amendoinzeiro & 172 \\
\hline Frankliniella brevicaulis & bananeira & 15 \\
\hline F. gemina & tomateiro & 8 \\
\hline F. insularis & crisântemo e feijão-guandu & 8 \\
\hline F. occidentalis & crisântemo & 73 \\
\hline F. schultzei & $\begin{array}{l}\text { algodoeiro, amendoinzeiro, } \\
\text { girassol, melancia e soja }\end{array}$ & 108 \\
\hline Heliothrips haemorrhoidalis & citros & 9 \\
\hline Palleucothrips musae & bananeira & 11 \\
\hline Selenothrips rubrocinctus & eucalipto & 13 \\
\hline Stenchaetothrips minutus & pimentão & 6 \\
\hline Thrips palmi & $\begin{array}{l}\text { batata, beringela, crisânte- } \\
\text { mo, pimentão e tomateiro }\end{array}$ & 128 \\
\hline T. tabaci & $\begin{array}{l}\text { alho, aspargo, cebola, } \\
\text { cebolinha e soja }\end{array}$ & 93 \\
\hline TOTAL & & 767 \\
\hline
\end{tabular}

* nome científico das plantas hospedeiras no próprio texto. 


\subsection{Chaves para identificação}

\subsubsection{Chave para as subordens de Thysanoptera}

1a. Asas anteriores, quando presentes, com nervuras de cerdas longitudinais freqüentemente indistintas e, algumas vezes, com nervuras transversais; superfície das asas coberta com microtríquias; fêmea com ovipositor visível; segmento abdominal $\mathrm{X}$ geralmente cônico; esternito abdominal VIII geralmente não desenvolvido mas, se presente, não separado do VII . . . . . . . . . . TEREBRANTIA

1b. Asas anteriores, quando presentes, sem nervuras; superfície das asas sem microtríquias; fêmea sem ovipositor visível; segmento abdominal $\mathrm{X}$ tubular; esternito abdominal VIII bem desenvolvido, distintamente separado do VII TUBULIFERA

\subsubsection{Chave para as familias mais comuns de Terebrantia}

1a. Fêmea com ovipositor pouco desenvolvido; esternito abdominal VIII bem desenvolvido; tergito abdominal $\mathrm{X}$ geralmente com um par de tricobótrias; antena com 8 segmentos distintamente separados, nunca formando um estilo; segmento antenal VIII delgado e longo; áreas sensoriais nos segmentos antenais III e IV transversais, ao redor do ápice (sem circundá-lo totalmente) MEROTHRIPIDAE

1b. Fêmea com ovipositor bem desenvolvido; esternito abdominal VIII não desenvolvido; tergito abdominal $\mathrm{X}$ geralmente sem tricobótrias que, se presentes, são muito

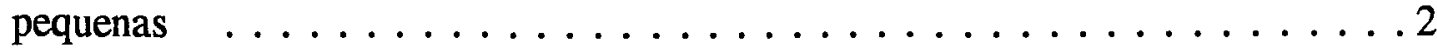

2a. Fêmea, em vista lateral, com ovipositor voltado para cima (em direção ao corpo); antena com 9 segmentos; segmentos antenais III e IV geralmente com áreas sensoriais lineares longitudinais, próximas ao ápice; asas anteriores largas, com numerosas nervuras transversais $\ldots \ldots \ldots \ldots \ldots$ AEOLOTHRIPIDAE

2b. Fêmea, em vista lateral, com ovipositor voltado para baixo (em direção contrária ao corpo); antenas geralmente com 7-8 segmentos, raramente com 9; segmentos 
antenais III e IV com sensilos; algumas espécies com áreas sensoriais contínuas, em forma de faixa, próximas ao ápice do segmento antenal e nunca com áreas sensoriais

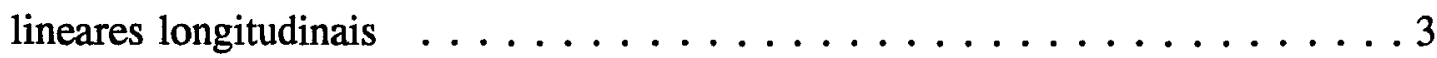

3a. Áreas sensoriais nos segmentos antenais III e IV contínuas e em formato de faixa ao redor do ápice $\ldots \ldots \ldots \ldots \ldots \ldots \ldots$ HETEROTHRIPIDAE

3b. Áreas sensoriais nos segmentos antenais III e IV desenvolvidas em sensilos delgados furcados ou simples $\ldots \ldots \ldots \ldots \ldots \ldots \ldots$ THRIPIDAE

\subsubsection{Chave para as subfamilias de Thripidae}

1a. Cabeça, pronoto e abdome cobertos com forte reticulação; segmentos antenais III e IV geralmente sem microtríquias; segmentos terminais freqüentemente muito longos e afilados; primeira nervura da asa anterior muito próxima à nervura costal; coloração do corpo frequentemente negra ou marrom-escura $\ldots \ldots \ldots \ldots$

1b. Cabeça, pronoto e abdome freqüentemente ornamentados de várias formas, mas nunca cobertos com ornamentação conspícua e reticulada; segmentos antenais III e IV geralmente com microtríquias; segmento terminal raramente alongado; asa anterior com a primeira e segunda nervuras distintas; corpo de coloração variada THRIPINAE

\subsubsection{Chave para os gêneros e espécies de Panchaetothripinae coletados}

1a. Asas anteriores com cílios lisos na margem posterior; sensilos dos segmentos antenais III e IV simples (Fig. 4D e 16C) $\ldots \ldots \ldots \ldots \ldots \ldots \ldots \ldots 2$

1b. Asas anteriores com cílios ondulados na margem posterior; sensilos dos segmentos antenais III e IV geralmente furcados (Fig. 2D e 19D) $\ldots \ldots \ldots \ldots \ldots 3$

2a. Cerdas das asas anteriores longas, com ápices expandidos; cerdas póstero-angulares 
do pronoto longas (Fig. 4B); furca mesotorácica sem espínula na margem anterior $\ldots \ldots \ldots \ldots \ldots \ldots \ldots \ldots \ldots \ldots$ E. . . . . . . . . .

2b. Cerdas das asas anteriores e cerdas póstero-angulares do pronoto pequenas e inconspícuas (Fig. 16B); furca mesotorácica com uma espínula

\section{Heliothrips haemorrhoidalis}

3a. Cabeça constricta posteriormente (Fig. 19A); pronoto com esculturação transversal estriada (Fig. 19B); tergito abdominal X não dividido (Fig. 20); tergito VIII com craspedum completo, com dentes em toda sua extensão, na margem posterior (Fig. 20); asas escuras; primeira e segunda nervuras da asa anterior com uma fileira completa de cerdas robustas e escuras ........ Selenothrips rubrocinctus

3b. Cabeça sem constrição posterior (Fig. 2A); esculturação do pronoto mais reticulada (Fig. 2B); tergito abdominal X, pelo menos, parcialmente dividido (Fig. 3B); tergito VIII com craspedum completo e dentes lateralmente (Fig. 3B); asas anteriores com faixas; primeira nervura de cerdas da asa anterior incompleta $\ldots \ldots \ldots \ldots$ $\ldots \ldots \ldots \ldots \ldots \ldots \ldots \ldots$ Caliothrips phaseoli

\subsubsection{Chave para os gêneros e espécies de Thripinae}

1a. Superfície dos tergitos abdominais e, algumas vezes, também dos esternitos, com numerosas microtríquias; furca do meso e metanotos com espínula (SERICOTHRIPINI). Pronoto, geralmente, com pelo menos um par de cerdas longas (Fig. 5B); antena com 9 segmentos (Fig. 5D); cerdas maiores das asas e do corpo pontiagudas ou expandidas; tergitos abdominais com muitas fileiras de microtríquias ..... . . . . . . . . . . . . Enneothrips flavens

1b. Superfície dos segmentos abdominais geralmente sem microtríquias; raramente furca do meso e metatórax com espínula; pronoto geralmente retangular e tergitos abdominais terminais sem cerdas semelhantes a espinhos (THRIPINI) $\ldots \ldots 2$ 
2a. Tergito VIII sem ctenídeo. Coloração amarelo-pálida; olhos compostos bastante destadados (Fig. 18A); cerdas ocelares II conspícuas (Fig. 18A); tergito VIII com longo craspedum; tergito IX com muitas microtríquias; furca do metanoto em formato de lira . . . . . . . . . . Palleucothrips musae

2b. Tergito VIII com ctenídeo (Fig. 7A e 23B) $\ldots \ldots \ldots \ldots \ldots \ldots \ldots$

3a. Ctenídeo no tergito VIII situado ântero-lateralmente ao espiráculo (Fig. 7A); cerdas ocelares I presentes (Fig. 6A); antena com 8 segmentos (Fig. 6D); primeira nervura da asa anterior geralmente com uma fileira completa de cerdas . Frankliniella

A1. Pedicelo do segmento antenal III em formato de cálice (Fig. 6D). [Cerdas ocelares III dentro do triângulo ocelar (Fig. 6A); tergito VIII com pente esparso e incompleto (Fig. 7A); metanoto com esculturação reticulada na parte mediana e um

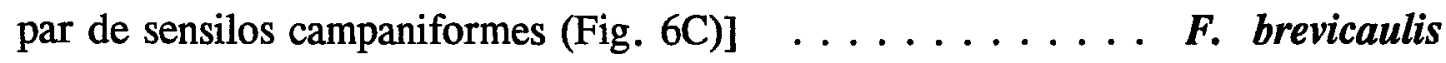

A2. Pedicelo do segmento antenal III simples $\ldots \ldots \ldots \ldots \ldots \ldots \ldots$

B1. Cerdas ocelares fora do triângulo ocelar (Fig. 10A); asas anteriores bicoloridas, principalmente escuras, mas pálidas na base; pente do tergito VIII bem desenvolvido, com dentes triangulares e curto intervalo medianamente (Fig. 11B) . . . . .

F. insularis

B2. Cerdas ocelares dentro do triângulo ocelar (Fig 8A); asas anteriores escuras ou pálidas, mas não bicoloridas; pente do tergito VIII completo ou quase ausente C

C1. Pente do tergito VIII incompleto ou quase ausente, com dentes curtos e de base larga (Fig. 15A); cerdas ocelares III inseridas dentro do triângulo ocelar e com bases muitos próximas (Fig. 14A) $\ldots \ldots \ldots \ldots \ldots \ldots$ F. schultzei

C2. Pente do tergito VIII completo (Fig. 13A); cerdas ocelares III dentro do triângulo ocelar 
D1. Coloração marrom-amarelada; cerdas b1 do tergito IX muito menores que b2 (Fig. 13B); tergitos abdominais com manchas marrons na parte central; maiores cerdas pós-oculares muito longas, às vezes, quase tão longas quanto as cerdas ocelares III (Fig. 12A) $\ldots \ldots \ldots \ldots \ldots \ldots \ldots \ldots \ldots \ldots \ldots$ occidentalis

D2. Coloração amarelo-clara; cerdas b1 do tergito IX um pouco menores que b2 (Fig. 9B); tergitos abdominais sem manchas marrons na parte central ... F. gemina

3b. Ctenídeo no tergito VIII situado póstero-medianamente ao espiráculo (Fig. 23B); cerdas ocelares I ausentes (Fig. 22A); antenas com 7-8 segmentos (Fig. 22B); primeira nervura de cerdas incompleta (falha na fileira de cerdas) . . . Thrips

A1. Cerdas ocelares III situadas dentro do triângulo ocelar (Fig. 24A); tergito II com 3 cerdas laterais (Fig. 25A); esculturação do metanoto com poucas reticulações medianamente (Fig. 24C); metanoto sem sensilo campaniforme (Fig. 24C); crescente ocelar acinzentado . . . . . . . . . . . T. tabaci

A2. Cerdas ocelares III situadas fora do triângulo ocelar (Fig. 22A); tergito II com 4 cerdas laterais (Fig. 23A); esculturação do metanoto longitudinal estriada, convergindo posteriormente (Fig. 22C); metanoto com um par de sensilos campaniformes (Fig. 22C); crescente ocelar avermelhado . . . . . T. palmi

\subsection{Caracterização das espécies de Thysanoptera coletadas}

As espécies de tripes estão relacionadas em ordem alfabética.

\subsubsection{Caliothrips phaseoli (Hood, 1912)}

Fêmea. Macróptera. Coloração marrom-escura; asas (faixas claras), tarsos, extremidade apical das tíbias, parte anterior da cabeça e metade basal dos segmentos antenais III, IV e $\mathrm{V}$ amarelados. 
Cabeça. Mais larga que longa, sem constrição posterior; superfície dorsal com forte esculturação reticulada, inclusive dentro do triângulo ocelar, com cada retículo (exceto aqueles nas fileiras posteriores) apresentando dobras internas. Cerdas ocelares III e pós-oculares proporcionalmente bem desenvolvidas e de difícil visualização, devido à cor clara (Fig. 2A). Palpos maxilares com dois segmentos. Antena com oito segmentos; segmentos III e IV com sensilos furcados torcidos; segmento VIII longo e afilado (Fig. 2D). Olhos compostos com seis facetas pigmentadas.

Tórax. Pronoto quadrangular, com cerdas pouco desenvolvidas; esculturação reticulada; retículos com dobras internas, exceto uns poucos retículos claros, em ambos os lados, na parte mediana (Fig. 2B). Metanoto com esculturação reticulada; retículos centrais subdivididos por dobras internas; inserção das cerdas medianas abaixo da margem anterior; sensilos campaniformes ausentes (Fig. 2C). Pterotórax largo (parte mais larga do corpo), com contorno oval. Asas anteriores bicoloridas, com a extremidade, uma pequena área basal e uma larga faixa mediana marrons; algumas vezes, esta faixa apresenta-se mais pálida medianamente; nervuras sem cerdas longas. Tarsos com um segmento.

Abdome. Laterais dos tergitos com esculturação transversal e oblíqua estriada (estrias unidas) sem dobras internas e com pouquíssimas microtríquias (Fig. 3A). Tergitos com estrias nas laterais. Tergito VIII com craspedum completo e dentes lateralmente; ctenídeo ausente. Tergito IX fracamente reticulado na metade anterior; cerdas b1 menores que b2. Tergito $\mathrm{X}$ parcialmente dividido próximo à extremidade (Fig. 3B).

Macho. Macróptero (asas bicoloridas, como nas fêmeas). Coloração semelhante a da fêmea. Esternitos abdominais III a VII com área glandular transversal alongada, um pouco mais estreita na região mediana. Margem posterior do tergito VIII com projeção longa.

Material examinado. BRASIL. São Paulo: Ilha Solteira, 14-xi-1993 (C. Almeida), 3 

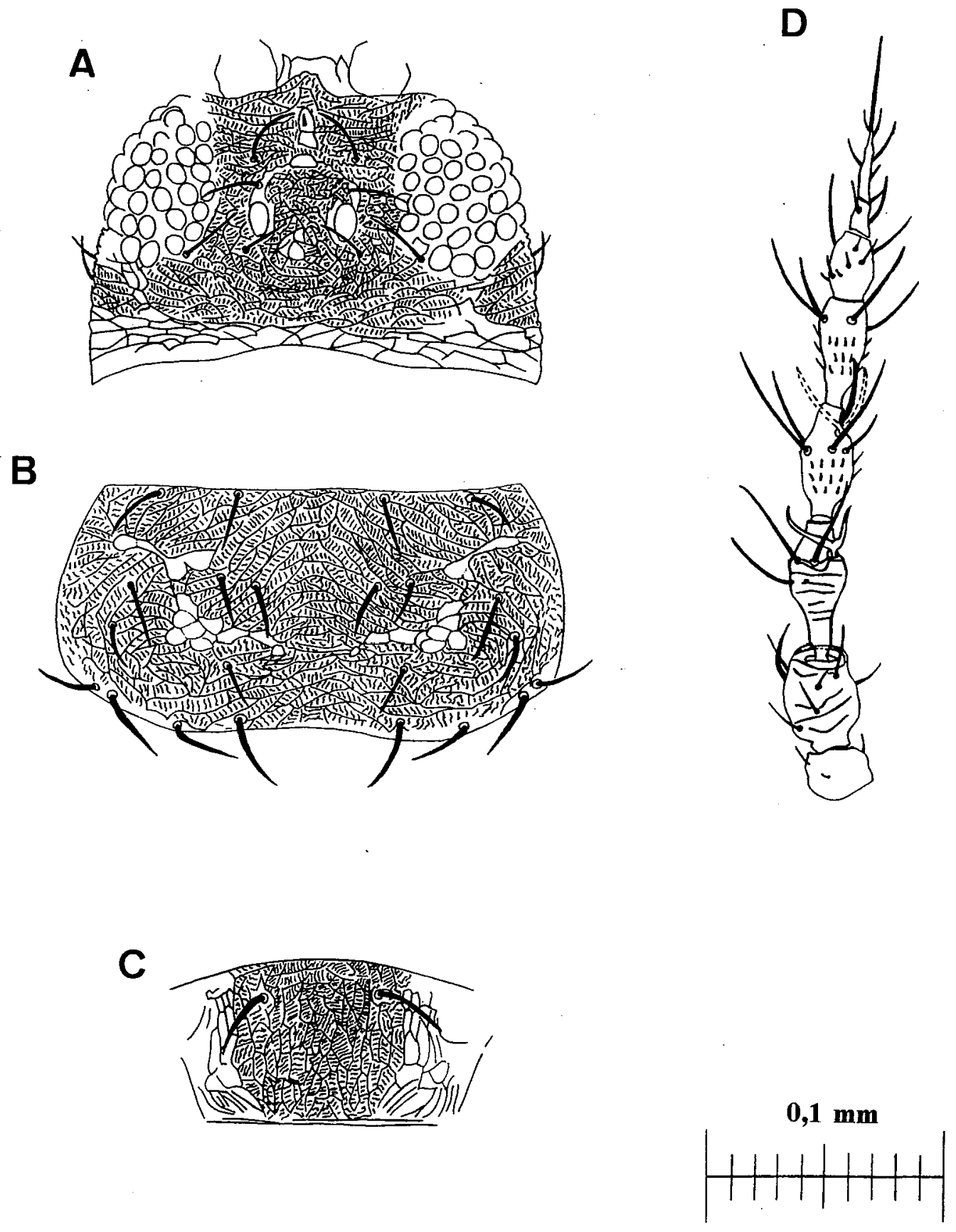

Figura 2. Caliothrips phaseoli. A. cabeça (dorsal); B. pronoto; C. metanoto; D. antena. 

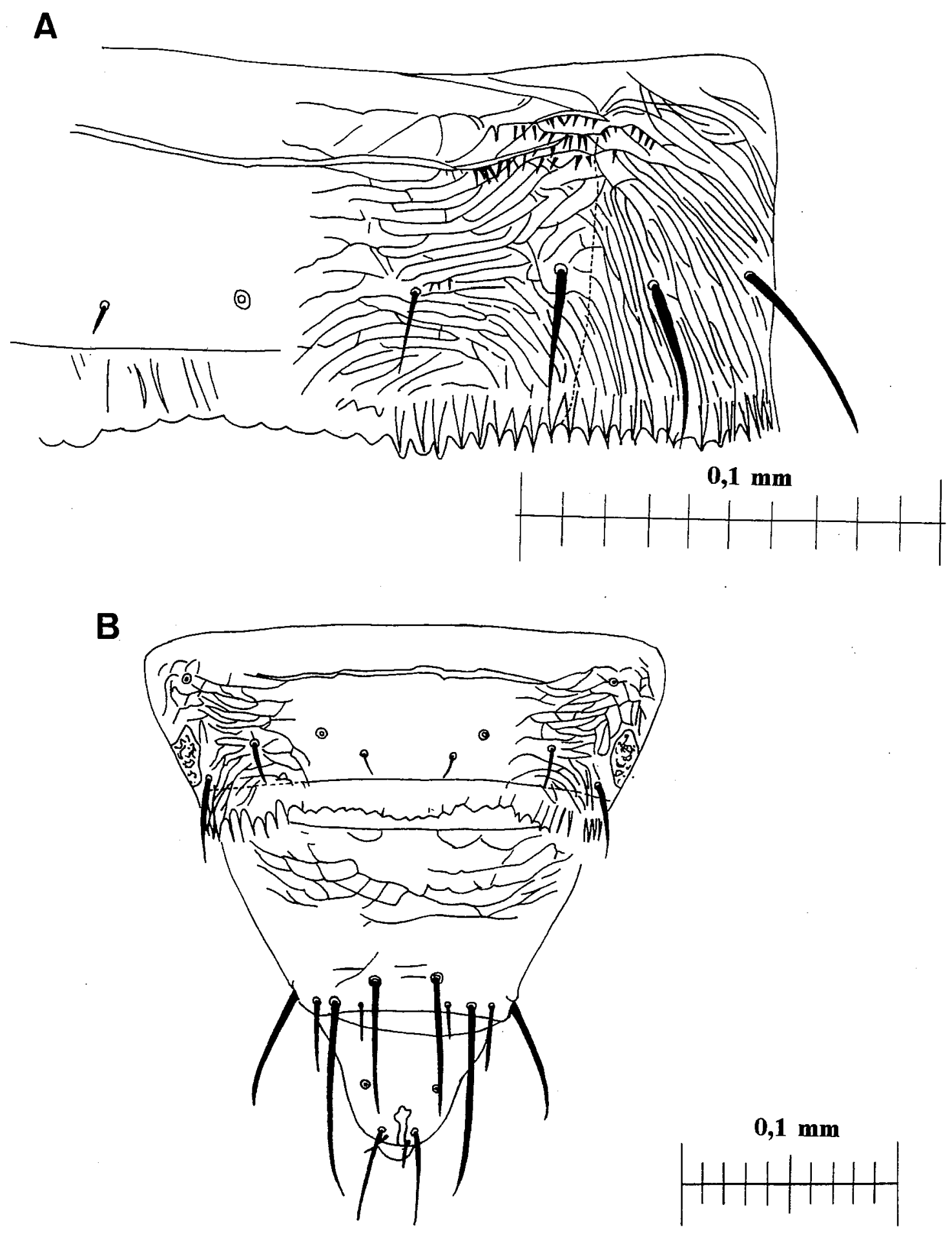

Figura 3. Caliothrips phaseoli. A. pleurotergito abdominal V; B. tergitos abdominais VIII-XI. 
I e 1 o (ESALQ), em soja Glycine max; Jaboticabal, iii-1992 (N.M. Martinelli), 10 + e 1 ơ (ESALQ e IBUNAM), em feijão Phaseolus vulgaris; Piracicaba, 23-viii1993 (A.R. Tavares), 1 (ESALQ), em girassol Helianthus annuus; idem, 16-xii1993 (R.C. Monteiro e N.A. Canal D.), 10 e 4 ơ (ESALQ), em soja; idem, 11-i1994 (E.A. Magrini), 10 e 2 o (ESALQ), em soja; idem, 20-i-1994 (E.A. Magrini), 2 e 3 ơ (ESALQ), em soja; idem, 27-i-1994 (E.A. Magrini), 4 e 3 o (ESALQ), em soja; Campinas, xi-1991 (A.L. Lourenção), 10 ? e 1 (ESALQ), em soja; idem, 19-i-1994 (R.C. Monteiro e J.A. Cerignoni), 13 ๆ e 6 o (ESALQ), em soja. araná: Bandeirantes, 06-xi-1993 (L. Mihsfeldt), 17 ㅇ e 5 ơ (ESALQ), em soja.

Comentários. $O$ gênero Caliothrips apresenta cerca de 20 espécies (MOUND et al., 1993). Segundo PALMER et al. (1989), essa espécie encontra-se amplamente dispersa nas Américas do Sul e Central e no sul dos EUA, e é coletada comumente em plantas de ervilhas, feijoeiro e algodoeiro. Wilson ${ }^{9}$ citado por NAKAHARA (1991b) considerou os espécimens da Flórida e Geórgia, cujas asas anteriores apresentavam a faixa mediana marrom uniforme, como variação na coloração de $C$. phaseoli. No entanto, NAKAHARA (1991b), estudando estes espécimens, assim como outros da Flórida, Geórgia. Louisiana, Carolina do Norte e Tennessee, com faixa mediana marrom uniforme nas asas, concluiu que representavam uma espécie distinta, Caliothrips multistriatus Nakahara, 1991. C. multistriatus apresenta esculturação tergal com dobras internas entre as linhas transversais. $O$ típico norteamericano $C$. phaseoli tem a faixa mediana das asas anteriores uniformemente escura (como em C. multistriatus). Todos os espécimens disponíveis de $C$. phaseoli não apresentam dobras internas entre as linhas transversais e considera-se que as populações do norte e do sul representam uma única espécie. $C$. phaseoli alimenta-se

\footnotetext{
${ }^{9}$ WILSON, T.H. A monograph of the subfamily Panchaetothripinae (Thysanoptera: Thripidae). Gainesville, American Entomological Institute, 1975. 354p. (Memoirs of the American Entomological Institute, 23).
} 
de plantas cultivadas e daninhas, tais como algodoeiro, gramíneas, figo, videira e tomateiro (KONO \& PAPP, 1977). No Brasil, SILVA et al. (1968) relataram sua ocorrência em folhas de Apocináceas, Convolvuláceas e Leguminosas (amendoim, ervilha, feijoeiro, mangalô e soja), nos Estados da Bahia, Rio de Janeiro e Rio Grande do Sul. É uma espécie comumente associada à soja e ao feijoeiro. Segundo ROSSETTO et al. (1974) e ALMEIDA et al. (1994), C. phaseoli, referido como Caliothrips braziliensis, foi a espécie mais comum encontrada em feijoeiro e soja, respectivamente.

\subsubsection{Echinothrips sp.}

Fêmea. Macróptera. Coloração marrom; tarsos, extremidade apical das tíbias, parte apical do segmento antenal III e segmento IV amarelados.

Cabeça. Com esculturação reticulada entre e logo após os ocelos; esculturação transversal estriada na parte posterior. Cerdas relativamente desenvolvidas (Fig. 4A). Antena com oito segmentos; sensilos dos segmentos antenais III e IV simples; segmento II com duas cerdas de ápice expandido (truncado) e base saliente; segmentos III-VII com microtríquias (Fig. 4D).

Tórax. Pronoto quadrangular e com esculturação reticulada, exceto duas áreas centrais claras; cerdas relativamente desenvolvidas; dois pares (póstero-marginal e pósteroangular) de cerdas desenvolvidas, robustas e com ápice expandido (Fig. 4B). Furca do mesotórax sem espínula. Metanoto com esculturação reticulada; par de cerdas medianas relativamente desenvolvidas (aproximadamente 1/4 do comprimento do metanoto), inseridas abaixo da margem anterior; sensilos campaniformes ausentes (Fig. 4C). Asa com cerdas curtas, robustas e com ápice expandido, na primeira nervura e cerdas longas e com ápice também expandido, na margem anterior. 

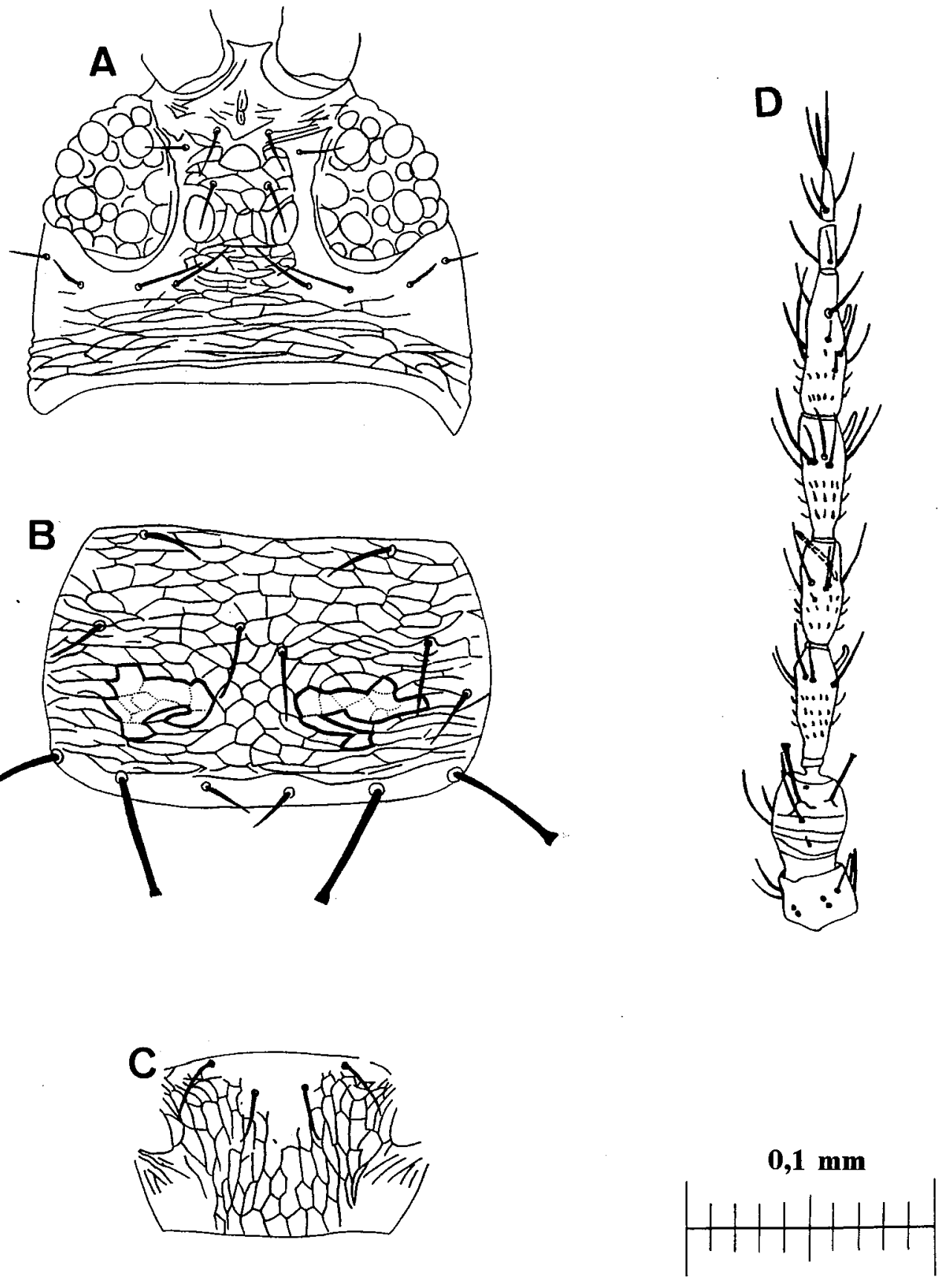

Figura 4. Echinothrips sp. A. cabeça (dorsal); B. pronoto; C. metanoto; D. antena. 
Abdome. Tergito VIII com pente póstero-marginal completo, com dentes longos, finos e de base estreita; ctenídeo ausente; um par de poros presentes; microtríquias na parte mediana-posterior. Tergito $\mathrm{X}$ com um par de poros. Tergitos com cerdas discais longas, maiores que a distância entre suas bases. Tergitos I-VII com esculturação lateral, cujas estrias marrom-escuras apresentam uma parte mais clara.

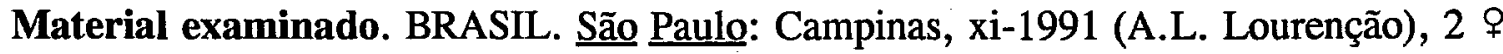
(ESALQ), em soja Glycine max; idem, i-1992 (A.L. Lourenção), 15 ๆ (ESALQ), em soja.

Comentários. O gênero Echinothrips inclui sete espécies do Novo Mundo (MOUND et al., 1993). Segundo Mound ${ }^{10}$, os exemplares coletados pertencem a uma espécie semelhante a Echinothrips mexicanus Moulton, 1911. E. mexicanus foi relatada no Brasil, em folhas de Eucalyptus citriodora, no Estado da Bahia (SILVA et al., 1968). Uma espécie do gênero Echinothrips, coletada em solo de um plantio de soja, foi relatada por ALMEIDA et al. (1994), no Paraná.

\subsubsection{Enneothrips flavens Moulton, 1941}

Fêmea. Macróptera. Coloração predominantemente amarelo-amarronzada; cabeça marrom; protórax marrom nas laterais e no terço posterior, terços mediano e anterior amarelo-claros; meso e metanoto marrons e pterotórax amarelo; tergitos abdominais com mancha mediana transversal de tonalidade marrom; segmentos antenais marrons, exceto a base e a extremidade do III e a base do IV; pernas amarelo-claras; asas anteriores marrons, exceto uma área clara próxima à base; cerdas marrons.

Cabeca. Com esculturação transversal estriada (estrias bastante próximas), exceto dentro

${ }^{10}$ MOUND, L.A. (The Natural History Museum. London, UK) Comunicação pessoal, 1994. 
do triângulo ocelar. Cerdas ocelares I ausentes; cerdas ocelares III dentro do triângulo ocelar e cerca de uma e meia vezes tão longas quanto a distância entre suas bases; cerdas pós-oculares de mesmo tamanho (Fig. 5A). Antena com nove segmentos; segmentos III e IV com sensilos furcados e numerosas microtríquias; segmentos V e VI também com microtríquias; segmentos VII-IX pequenos (Fig. 5D).

Tórax. Pronoto quadrangular, com esculturação transversal estriada (estrias muito próximas), exceto quatro áreas ovais claras (duas maiores e duas menores); com um par de cerdas póstero-angulares desenvolvidas, cerca de três vezes maior que os demais (Fig. 5B). Metanoto com esculturação oblíqua estriada nas laterais, esculturação transversal estriada na parte central superior e esculturação reticulada nas partes medianas central e inferior (Fig. 5C).

Abdome. Tergitos sem ctenídeo, mesmo no segmento VIII. Tergito VIII com pente póstero-marginal completo, com dentes longos e finos. Segmentos abdominais com esculturação transversal estriada nas laterais; tergitos com cerdas discais próximas, mais longas que a distância entre suas bases.

Macho. Braquíptero. Coloração semelhante à da fêmea. Tergito VIII com pente póstero-marginal completo, com dentes longos e finos. Região antecostal do esternito III com área glandular longa, larga, transversal e reticulada (Fig. 5E).

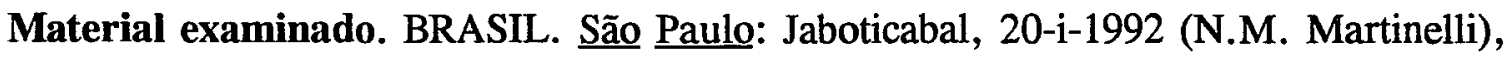
11 (ESALQ e BMNH), em amendoinzeiro Arachis hypogea; Piracicaba, 10-iv1991 (R.C. Monteiro), 32 ๆ e 2 ò (ESALQ, BMNH e IBUNAM), em amendoinzeiro; Campinas, xi-1992, xii-1992 e i-1993 (D. Gabriel), 19 \% (ESALQ) em amendoinzeiro; idem, 24-xi-1993 (D. Gabriel), 10 \% (ESALQ), em amendoinzeiro; idem, 30-xi-1993 (D. Gabriel), 19 \& (ESALQ), em amendoinzeiro; idem, 14-xii1993 (D. Gabriel), 15 \& (ESALQ), em amendoinzeiro; idem, 21-xii-1993 (D. Gabriel), 13 ๆ e 1 ơ (ESALQ), em amendoinzeiro; idem, 04-i-1994 (D. Gabriel), 


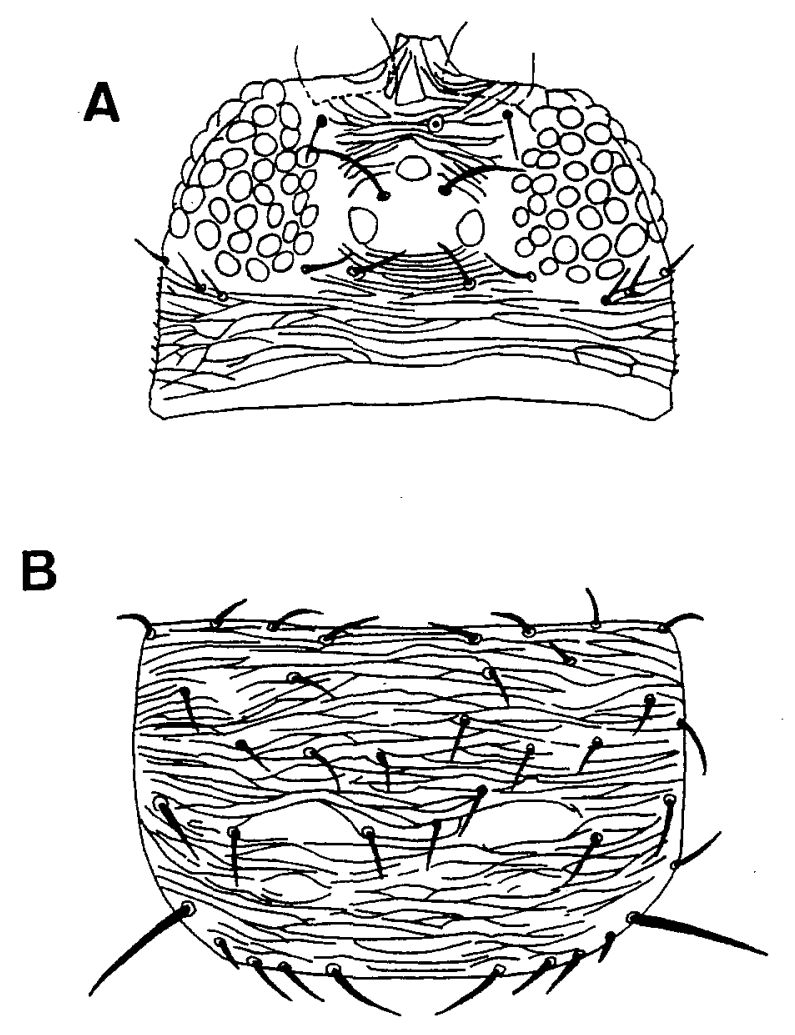

B
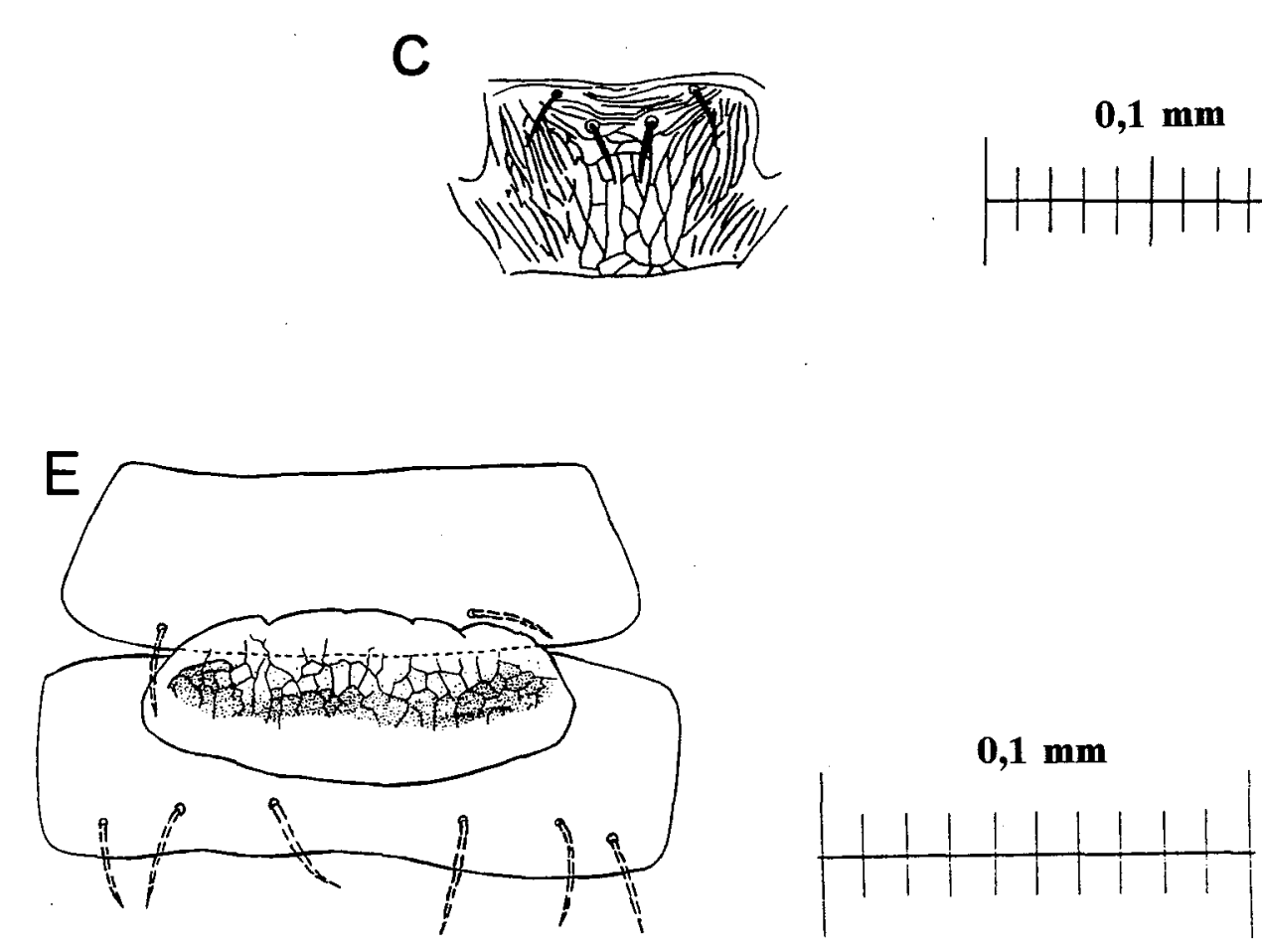

Figura 5. Enneothrips flavens. A. cabeça (dorsal); B. pronoto; C. metanoto; D. antena; E. esternitos abdominais II e III do ơ: área glandular. 
18 (ESALQ), em amendoinzeiro; idem, 11-i-1994 (D. Gabriel), 18 (ESALQ), em amiendoinzeiro; idem, 18-i-1994 (D. Gabriel), 13 \% e 1 o (ESALQ), em amendoinzeiro.

Comentários. O gênero Enneothrips apresenta cinco espécies neotropicais, que se alimentam de folhas (MOUND et al., 1993). E. flavens foi coletada exclusivamente em amendoinzeiro Arachis hypogea. Segundo MOULTON (1941), E. flavens é muito semelhante a Enneothrips gustaviae Hood, 1933, da qual diferencia-se pela coloração, presença de cerdas póstero-angulares desenvolvidas e ausência de pigmentação vermelha. Segundo Mound ${ }^{11}$, essa espécie também é semelhante a Enneothrips flaviceps Hood, 1955, uma espécie do Panamá. No Brasil, foi referido em chá-da-índia, no Estado de Minas Gerais (SILVA et al., 1968). Foram feitos estudos relacionados ao período críticio de ataque de $E$. flavens na cultura do amendoim (BATISTA et al., 1973), à importância da época de ocorrência (SILVA, 1977), à flutuação populacional (CASTRO et al., 1972) e à utilização de inseticidas no seu controle (BATISTA, 1971; SILVA, 1977). Há muito tempo vem sendo associado ao amendoinzeiro, onde é importante praga.

\subsubsection{Frankliniella brevicaulis Hood, 1937}

Fêmea. Macróptera. Coloração marrom-amarelada; segmentos antenais

I, II, VI, VII e VIII e parte apical dos segmentos III, IV e V mais escuros; pernas mais claras.

Cabeça. Esculturação transversal estriada; estrias fracas e reduzidas, na parte posterior (uma das estrias um pouco mais nítida). Cerdas ocelares III dentro do triângulo ocelar, afastadas e situadas próximas à margem anterior dos ocelos posteriores;

${ }^{11}$ MOUND, L.A. (The Natural History Museum. London, UK) Comunicação pessoal, 1994. 
cerdas pós-oculares pouco desenvolvidas (Fig. 6A). Antena com oito segmentos; segmentos III e IV com sensilos furcados; pedicelo do segmento III em formato de cálice e sem anel com bordos pontiagudos (Fig. 6D).

Tórax. Pronoto quadrangular; esculturação transversal estriada; estrias fracas; quatro pares de cerdas bem desenvolvidas e um par medianamente desenvolvido (fig. 6B). Metanoto com esculturação reticulada mediana; terço superior com reduzida esculturação transversal estriada; terços mediano e inferior com esculturação reticulada poligonal; laterais com esculturação oblíqua estriada; cerdas medianas bastante longas, quase atingindo a margem posterior e inseridas na margem anterior; par de sensilos campaniformes presentes (Fig. 6C).

Abdome. Tergito VIII com pente póstero-marginal incompleto e esparso, com dentes relativamente curtos e de base larga; ctenídeo presente situado ântero-lateralmente ao espiráculo (Fig. 7A). Tergito IX com cerdas b1 um pouco menores que b2; dois pares de poros presentes (Fig. 7B).

Macho. Macróptero. Segmentos abdominais com manchas marrons na parte central. Esternitos III-VII com área glandular transversal linear alongada. Tergito VIII com pente póstero-marginal incompleto, com dentes curtos e de base larga.

Material examinado. BRASIL. São Paulo: Piracicaba 27-x-1993 (P. Degrande), 14 ㅇ e 1 ơ (ESALQ), em banana Musa sp.

Comentários: Apesar da espécie ter sido coletada em banana Musa sp., Mound ${ }^{12}$ considera que essa espécie provavelmente se associa a flores masculinas de milho Zea mays. Já havia sido relatada no Brasil, em frutos de bananeira, no Estado de São

${ }^{12}$ MOUND, L.A. (The Natural History Museum. London, UK) Comunicação pessoal, 1994. 


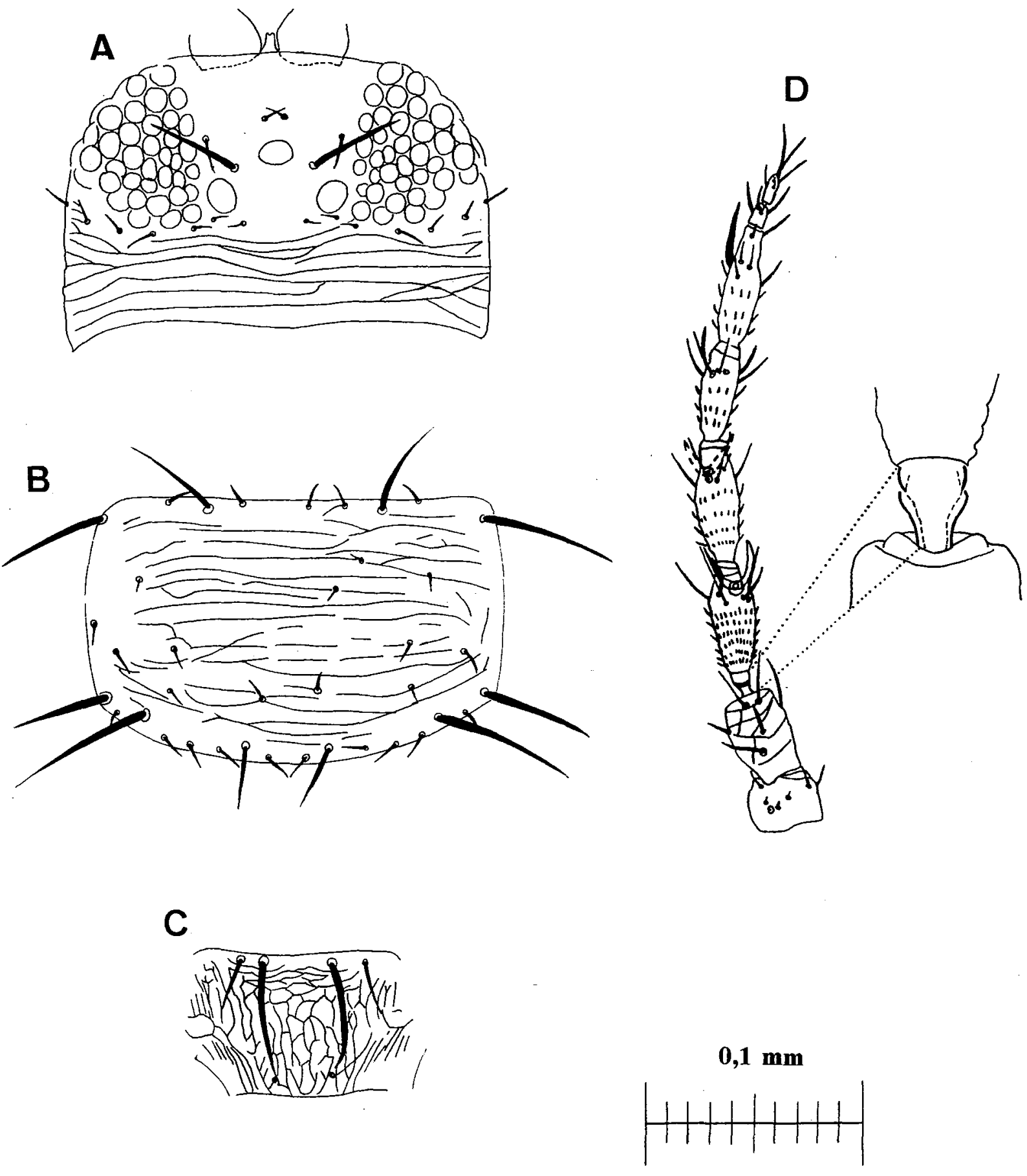

Figura 6. Frankliniella brevicaulis. A. cabeça (dorsal); B. pronoto; C. metanoto; D. antena (em destaque, detalhe do pedicelo do segmento III). 
A
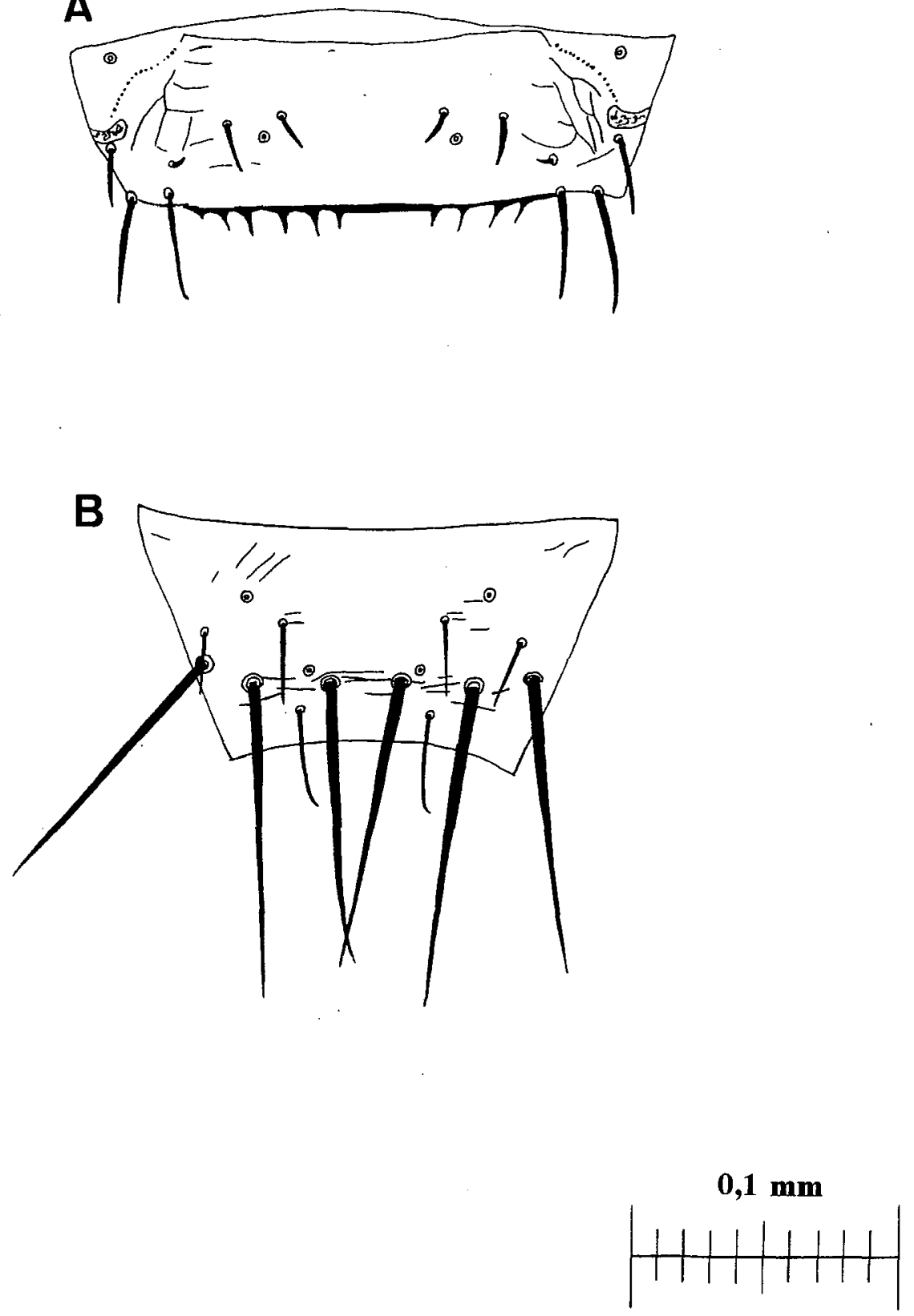

Figura 7. Frankliniella brevicaulis. A. tergito abdominal VIII; B. tergito abdominal IX. 
Paulo (SILVA et al., 1968).

\subsubsection{Frankliniella gemina Bagnall, 1919}

Fêmea. Macróptera. Coloração amarela; parte apical dos segmentos antenais II-V e segmentos VI-VIII marrons.

Cabeca. Parte posterior com fraca esculturação transversal estriada. Cerdas ocelares III dentro do triângulo ocelar e cerca de duas vezes maiores que a distância entre suas bases; apenas um par de cerdas pós-oculares desenvolvidas e outro par um pouco maior que os demais (Fig. 8A). Antena com oito segmentos; segmentos III e IV com sensilos furcados; segmentos VII e VIII pequenos (Fig. 8D).

Tórax. Pronoto quadrangular; esculturação transversal estriada; estrias fracas, que se fundem na parte mediana-posterior; quatro pares de cerdas bem desenvolvidas e um par medianamente desenvolvido (Fig. 8B). Metanoto com esculturação transversal estriada na parte mediana superior; partes medianas central $\mathrm{e}$ inferior com esculturação pouco reticulada; laterais com esculturação oblíqua estriada; par de sensilos campaniformes presentes (Fig. 8C).

Abdome. Tergitos com cerdas discais pequenas e distanciadas cerda de quatro vezes o seu comprimento. Laterais com esculturação oblíqua estriada. Tergito VIII com pente póstero-marginal completo, com dentes longos, finos e de base larga; ctenídeo presente situado ântero-lateralmente ao espiráculo (Fig. 9A). Tergito IX com cerdas b1 um pouco menores que b2 (Fig. 9B).

Material examinado. BRASIL. S尔o Paulo: Piracicaba, 09-ix-1993 (T.A. Giustolin), 8 i (ESALQ), em tomate Lycopersicon esculentum. 

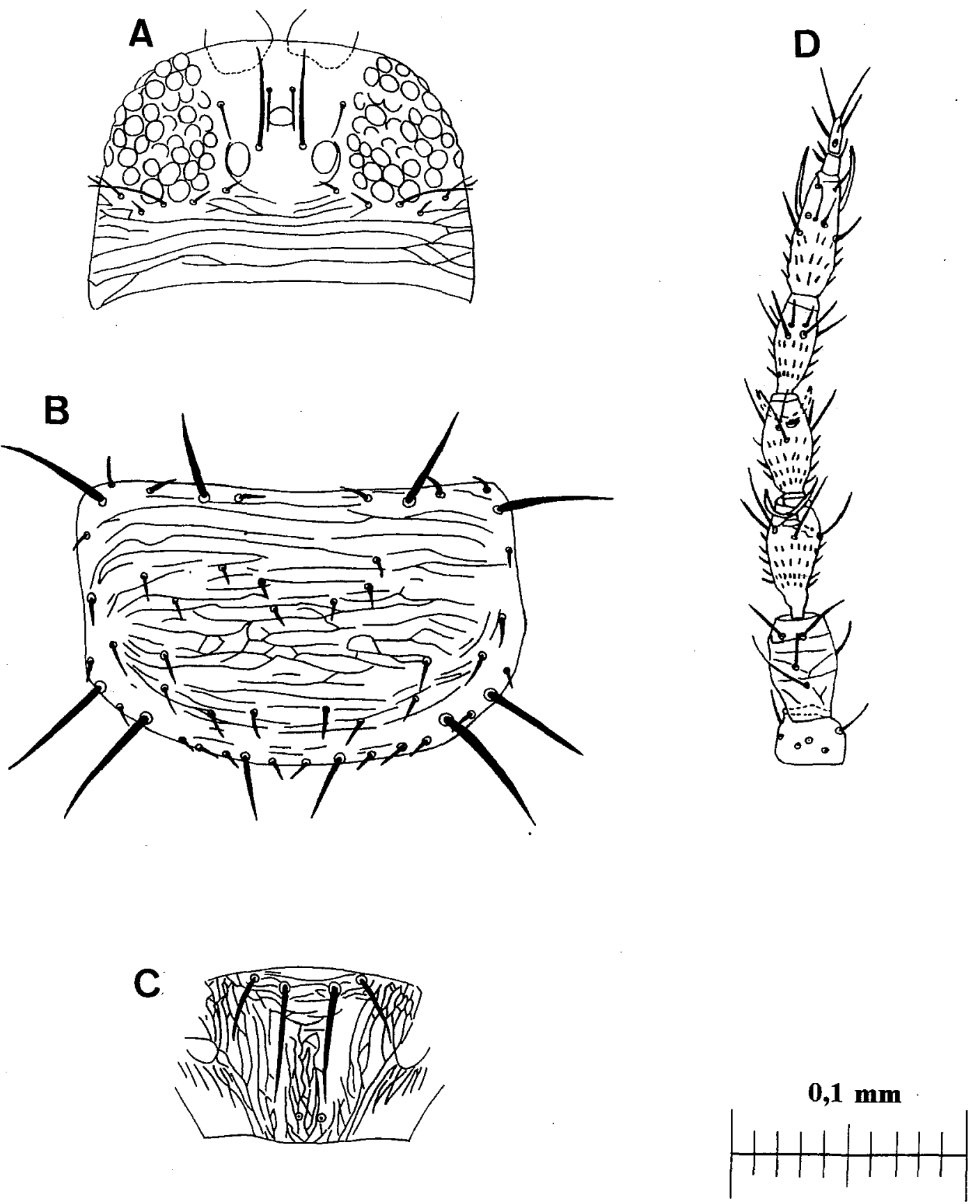

Figura 8. Frankliniella gemina. A. cabeça (dorsal); B. pronoto; C. metanoto; D. antena. 
A
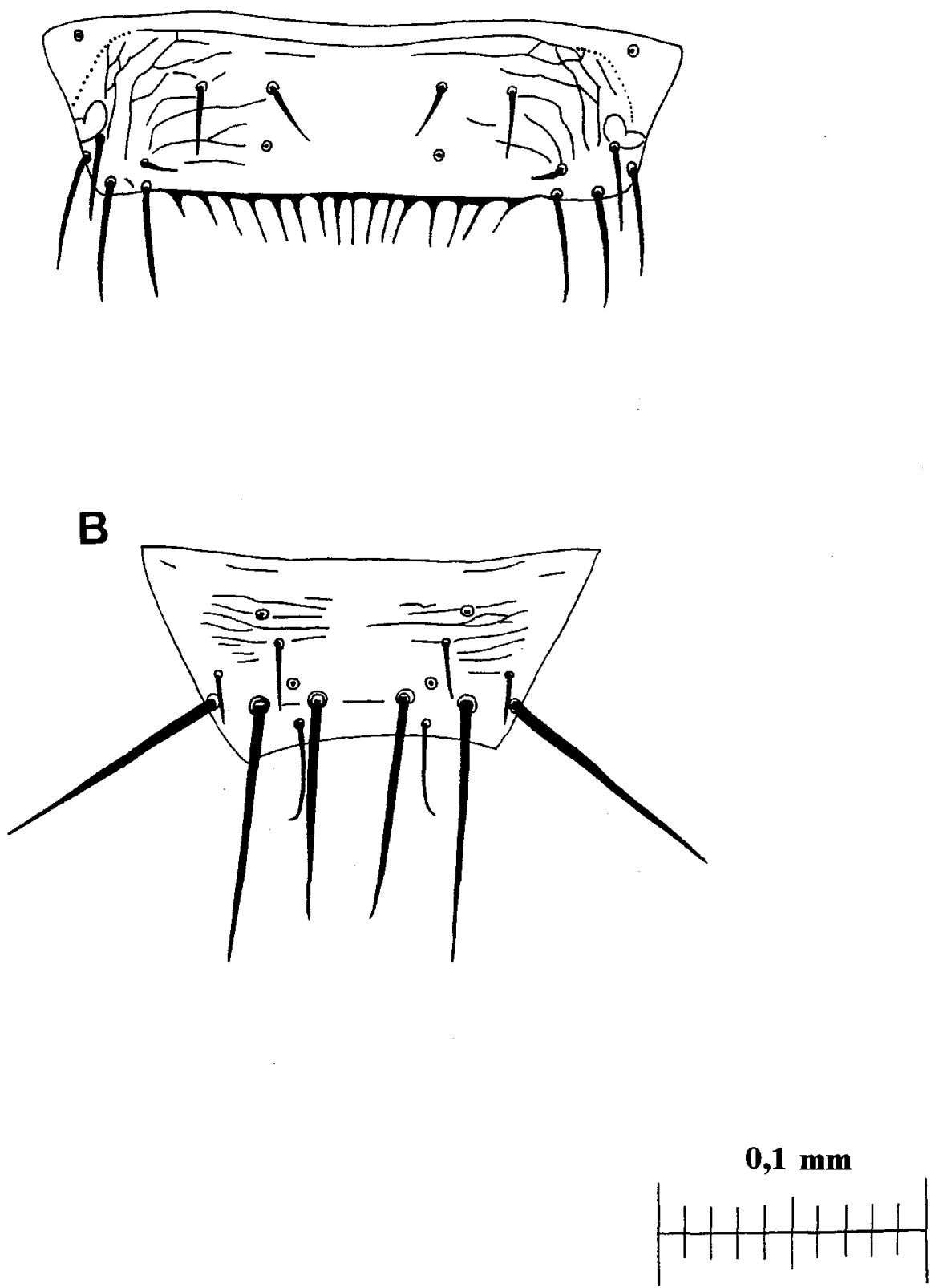

Figura 9. Frankliniella gemina. A. tergito abdominal VIII; B. tergito abdominal IX. 
Comentários. Espécie pequena, amarelo-clara, muito semelhante a $F$. williamsi Hood, 1915, da qual distingui-se por apresentar as cerdas ocelares próximas. Além disso, F. gemina não apresenta nenhuma cerda discal no esternito abdominal II, enquanto F. williamsi apresenta uma ou duas (Mound ${ }^{13}$ ). F. gemina foi coletada em Ambrosia polystachya, planta daninha encontrada na cultura da soja, no Paraná, e conhecida hospedeira do TSWV (ALMEIDA et al., 1994).

\subsubsection{Frankliniella insularis (Franklin, 1908)}

Fêmea. Macróptera. Coloração marrom-escura; tarsos, tíbias anteriores, parte basal dos segmentos antenais IV e V, segmento antenal III e base das asas anteriores claros.

Cabeça. Parte posterior com fraca esculturação transversal estriada. Cerdas ocelares III fora do triângulo ocelar e cerca de uma e meia vezes a distância entre suas bases; cerdas pós-oculares pequenas, exceto os dois pares laterais (par interno maior) (Fig. 10A). Antena com oito segmentos; segmentos III e IV com sensilos furcados e muitas microtríquias; segmentos V e VI também com microtríquias; segmentos VII e VIII pequenos (Fig. 11D).

Tórax. Pronoto quadrangular, com fraca esculturação transversal estriada; quatro pares de cerdas bem desenvolvidos e um par, medianamente desenvolvido (Fig. 10B). Metanoto com esculturação transversal estriada (estrias próximas) no terço mediano superior; terços medianos central e inferior com esculturação longitudinal estriada; laterais com esculturação oblíqua estriada; par de sensilos campaniformes presentes (Fig. 11A) (não observado em um exemplar).

${ }^{13}$ MOUND, L.A. (The Natural History Museum. London, UK) Comunicação pessoal, 1994. 

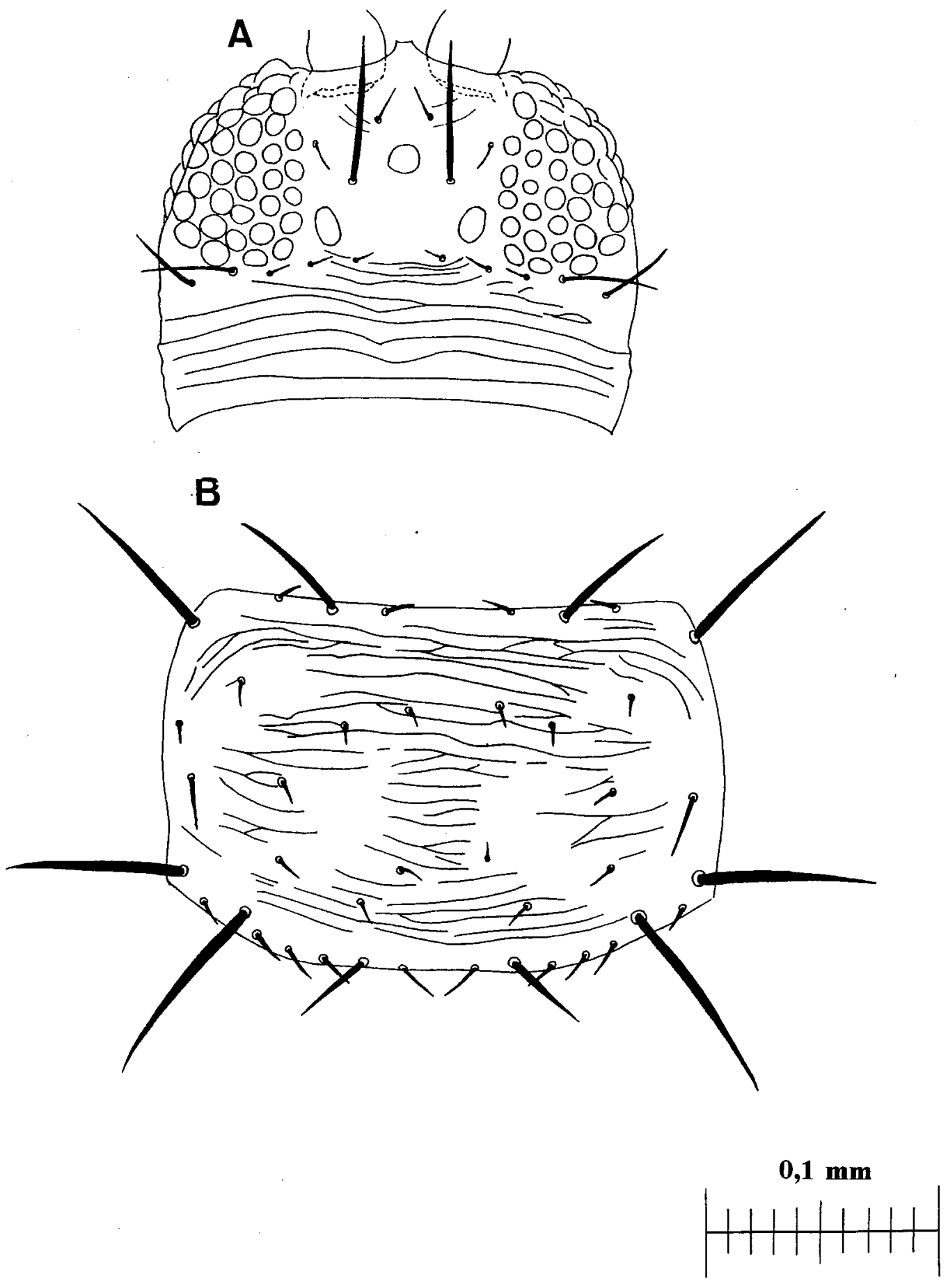

Figura 10. Frankliniella insularis. A. cabeça (dorsal); B. pronoto. 
Abdome. Tergito VIII com pente póstero-marginal incompleto, bem desenvolvido, com dentes triangulares e curto intervalo medianamente; ctenídeo presente, situado ânterolateralmente ao espiráculo (Fig. 11B). Tergito IX com cerdas b1 um pouco menores que b2 (Fig. 11C).

Macho. Semelhante à fêmea. Tergito VIII com pente póstero-marginal fracamente desenvolvido. Esternitos III-VII com uma área glandular transversal grande e larga (PALMER et al., 1989).

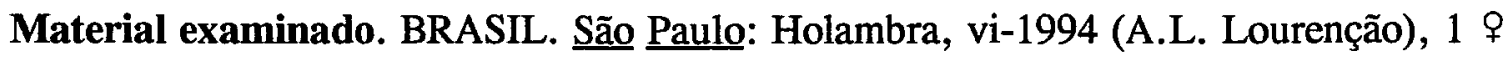
(ESALQ), em crisântemo Chrysantemum sp.; Campinas, vi-1993 (A.L. Lourenção), 7 (ESALQ e IBUNAM)), em feijão-guandu Cajanus cajan.

Comentários. Segundo Mound ${ }^{14}$, é uma espécie polífaga, amplamente dispersa, encontrada no México, nas Antilhas e nas Américas Central e do Sul. Por outro lado, Johansen, do IBUNAM, no México, estudou duas das sete fêmeas coletadas em Cajanus cajan listadas acima, e concluiu que elas podem representar uma nova espécie (Johansen ${ }^{15}$ ). Ataca fumo (LIMA, 1938) e foi relata em folhas de abacateiro, cafeeiro, Compositae, fumo, feijão-guandu, mangalô, Passiflora sp., trapoeiraba e laranjeira, nos Estados da Bahia, Espírito Santo, Minas Gerais, Rio de Janeiro, Rio Grande do Sul, Santa Catarina e São Paulo (SILVA et al., 1968).

4.3.7. Frankliniella occidentalis (Pergande, 1895)

Fêmea. Macróptera. Coloração marrom-amarelada; segmentos antenais

${ }^{14}$ MOUND, L.A. (The Natural History Museum. London, UK) Comunicação pessoal, 1994.

15 JOHANSEN, R.M. (Universid Autonoma del México. México city, MÉXICO) Comunicação pessoal, 1994. 
A

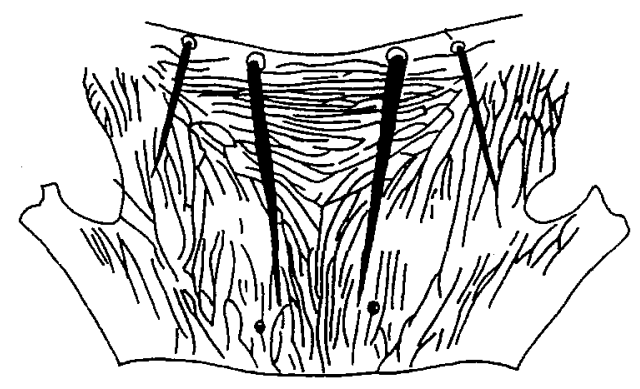

B
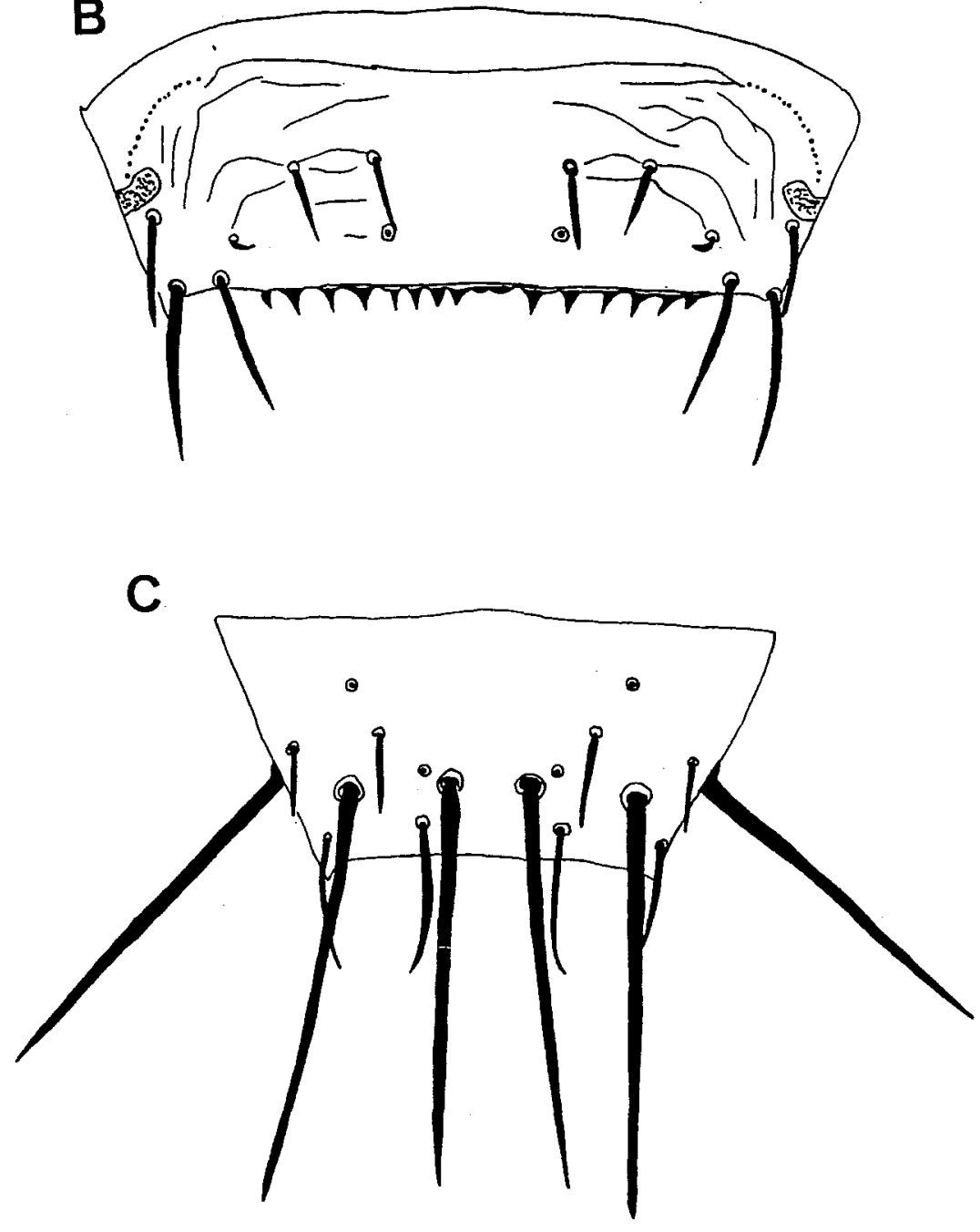

D

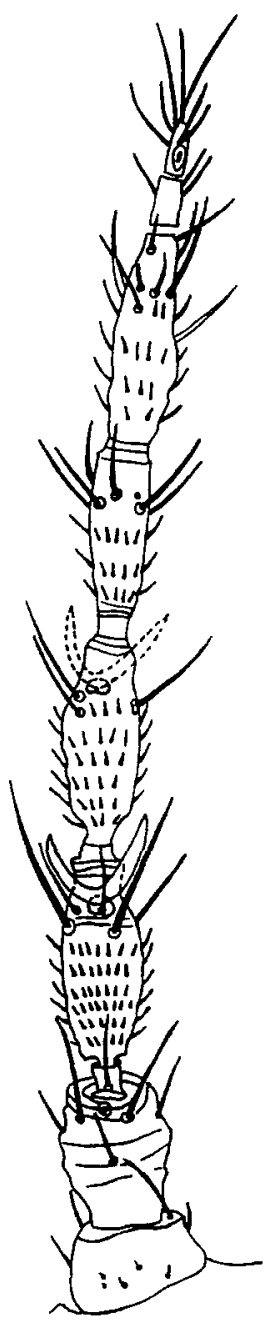

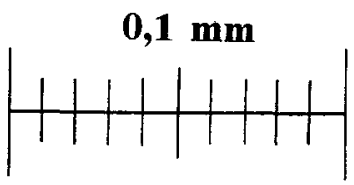

Figura 11. Frankliniella insularis. A. metanoto; B. tergito abdominal VIII; C. tergito abdominal IX; D. antena. 
I, II e parte basal dos segmentos III, IV e V amarelados; segmentos antenais VI, VII e VIII e parte apical dos segmentos III, IV e V marrom-escuros; asas claras e uniformes.

Cabeça. Não projetada além dos olhos; com esculturação transversal estriada na parte posterior. Cerdas ocelares III dentro do triângulo ocelar e próximas à margem anterior dos ocelos posteriores, cerca de duas vezes a distância entre suas bases; maiores cerdas pós-oculares muito longas, freqüentemente quase tão longas quanto às cerdas ocelares III (Fig. 12A). Antena com oito segmentos; segmentos III e IV com sensilos furcados e muitas microtríquias; segmentos $\mathrm{V}$ e VI também com microtríquias; segmentos VII e VIII pequenos (Fig. 12D).

Tórax. Pronoto quadrangular, com fraca esculturação transversal estriada; quatro pares de cerdas bem desenvolvidas e um par, medianamente desenvolvido (Fig. 12B). Metanoto com esculturação reticulada na parte mediana; laterais com reduzida esculturação estriada oblíqua; par de sensilos campaniformes presentes (Fig. 12C).

Abdome. Tergito VIII com pente póstero-marginal completo, com dentes medianamente longos e de base larga; ctenídeo presente situado ântero-lateralmente ao espiráculo (Fig. 13A). Ctenídeo presente também nos tergitos V-VII. Tergito IX com cerdas b1 muito menores que b2 (Fig. 13B). Tergitos I-VIII com manchas marrom-escuras medianas. Tergito $\mathrm{X}$ quase completamente dividido por um sulco longitudinal.

Macho. Macróptero. Coloração clara; parte apical dos segmentos antenais III, IV e V e segmentos VI, VII e VIII marrons. Tergito VIII com pente incompleto, esparso e com dentes pequenos e de base larga. Esternitos III-VII com uma área glandular oval pequena e transversal.

Material examinado. BRASIL. São Paulo: Holambra, 1993 (?), 17 \& e 3 o (ESALQ), em crisântemo Chrysantemum sp.; Jaguariúna, 12-iii-1994 (D. Pagotto), 12 q 


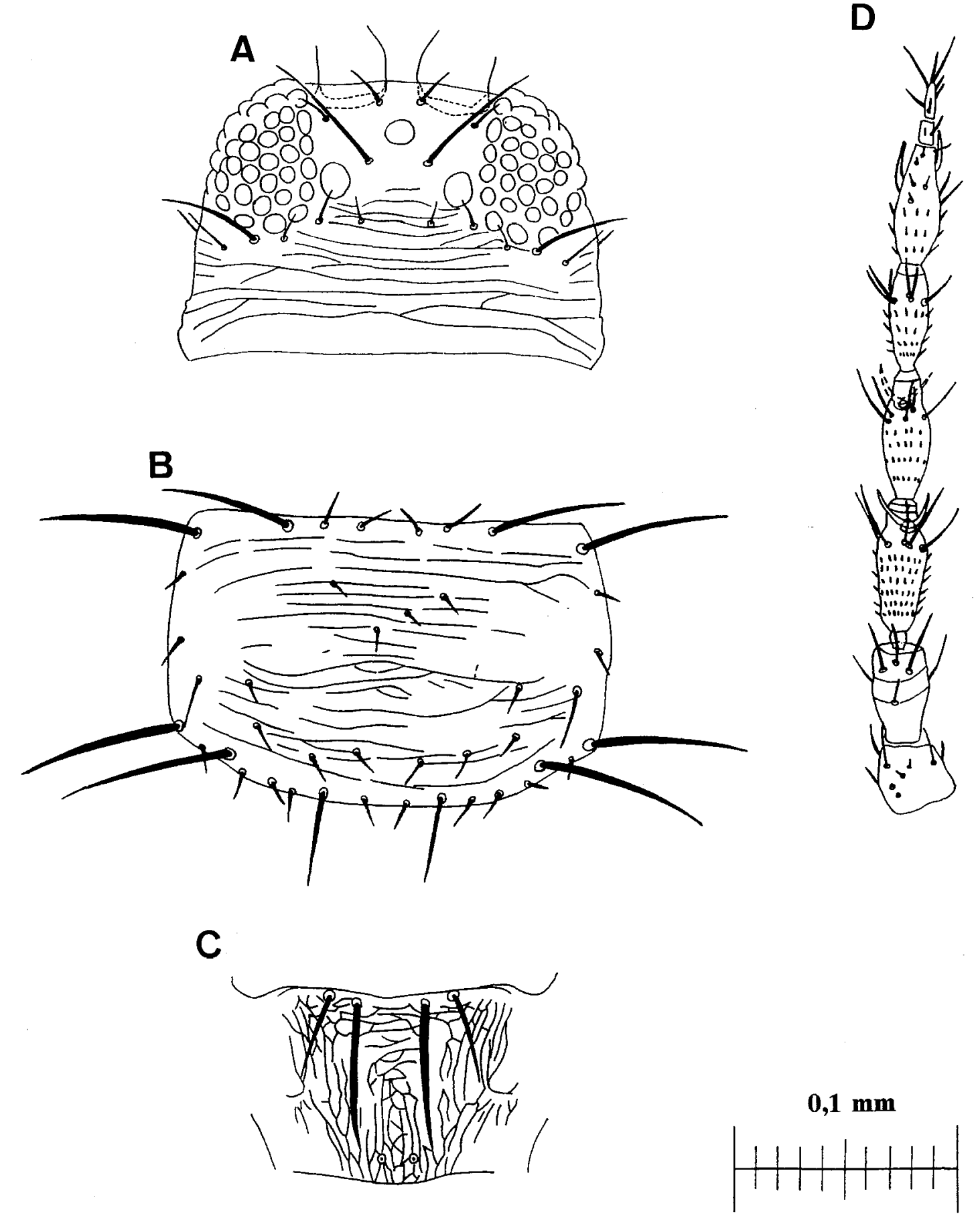

Figura 12. Frankliniella occidentalis. A. cabeça (dorsal); B. pronoto; C. metanoto; D. antena. 
A
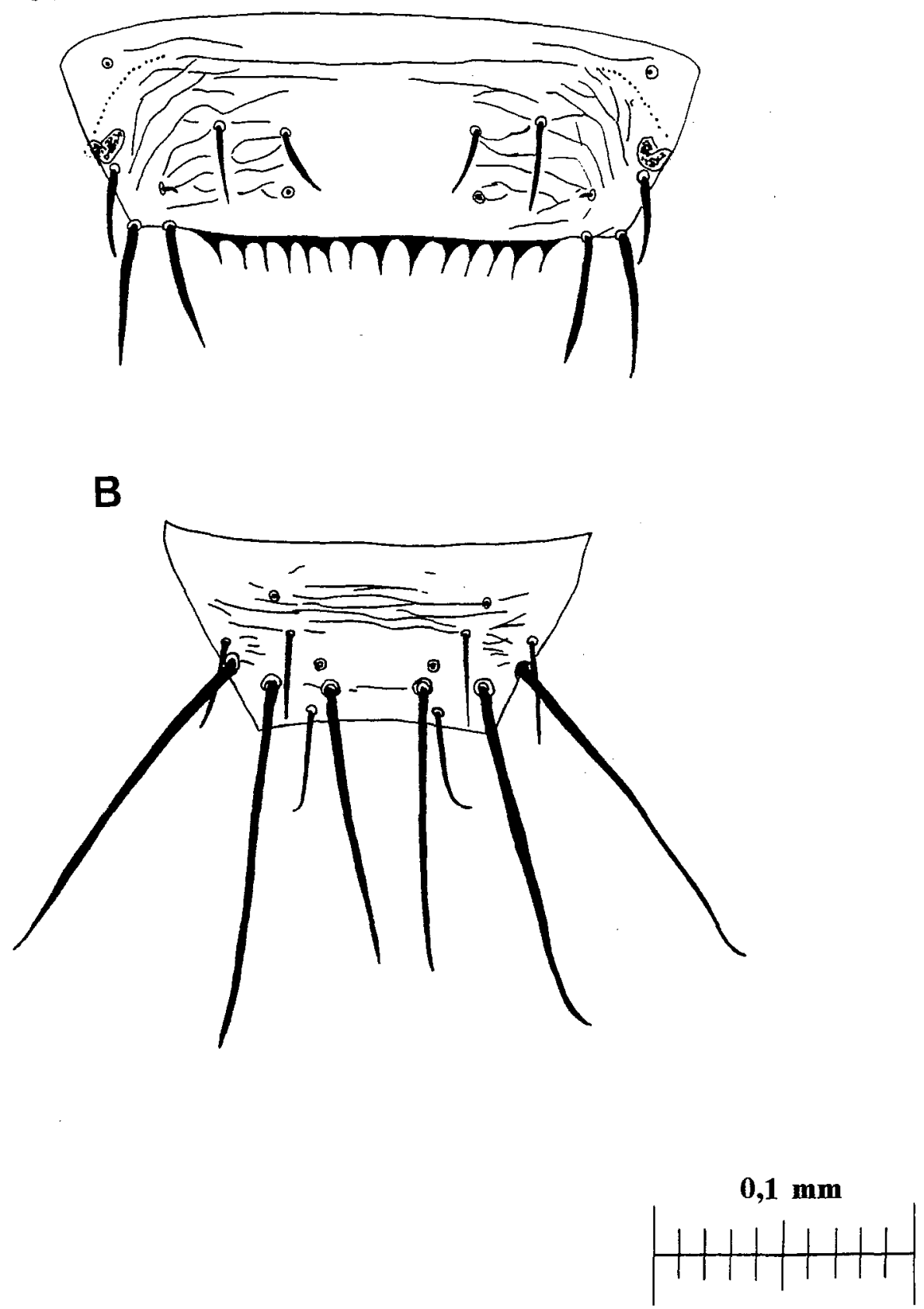

Figura 13. Frankliniella occidentalis. A. tergito abdominal VIII; B. tergito abdominal IX. 
(ESALQ), em crisântemo; Campinas, v-1992 (A.L. Lourenção), 13 9 (ESALQ), em crisântemo; Atibaia, 03-iii-1994 (M. Horie), 23 \% (ESALQ), em crisântemo; Paranapanema, 05-vii-1994 (V. Matida), 2 9 (ESALQ), em crisântemo.

Comentários. Segundo Mound ${ }^{16}$, a forma típica bicolorida é muito comum em casasde-vegetação. É uma espécie comum, polífaga e amplamente dispersa no oeste da América do Norte e Havaí, causando sérios danos particularmente às flores de corte, mudas de viveiros, pessegueiro, ameixeira, nectarina, videira e algodoeiro. É, aparentemente, o principal vetor do TSWV (WIJKAMP et al., 1993). SILVA et al. (1968) relataram a ocorrência dessa espécie em flores de alfafa, feijão, melão, tomateiro, videira e outras plantas, no Estado do Rio Grande do Sul, com base no trabalho de RADAELLI \& FERNANDES (1944). Entretanto, a referência anterior é uma simples nota, sem registro de coleção depositária dos exemplares, na qual $F$. occidentalis é listada com outras espécies de Thysanoptera. Portanto, esta é a primeira referência documentada de $F$. occidentalis, no Brasil.

\subsubsection{Frankliniella schultzei (Trybom, 1910)}

Fêmea. Macróptera. Coloração marrom; asas e a base dos segmentos antenais III e IV amarelados.

Cabeça. Com fraca esculturação transversal estriada na parte posterior (algumas estrias se fundem e uma delas é mais forte). Cerdas ocelares III dentro do triângulo ocelar, próximas na base e com comprimento cerca de três vezes a distância entre suas bases; cerdas pós-oculares pouco desenvolvidas, exceto um par (Fig. 14A). Antena com oito segmentos; segmentos III e IV com sensilos furcados e muitas microtríquias; segmentos VII e VIII pequenos (Fig. 14D).

\footnotetext{
${ }^{16}$ MOUND, L.A. (The Natural History Museum. London, UK) Comunicação pessoal, 1994.
} 
Tórax. Pronoto quadrangular, com fraca esculturação transversal estriada nos terços superior e inferior; terço mediano com esculturação reticulada ; quatro pares de cerdas bem desenvolvidas e um par, medianamente desenvolvido (Fig. 14B). Metanoto com esculturação transversal estriada na parte mediana superior; partes medianas central e inferior com esculturação pouco reticulada; laterais com pouca esculturação reticulada e com esculturação oblíqua estriada; par de cerdas medianas longas, com inserção na margem anterior; sensilos campaniformes ausentes (Fig. 14C).

Abdome. Tergito VIII com pente póstero-marginal incompleto ou quase ausente, pouco desenvolvido, com dentes curtos e de base larga; ctenídeo presente e situado ânterolateralmente ao espiráculo (Fig. 15A). Tergito IX com cerdas b1 menores que b2 (Fig. 15B).

Macho. Macróptero. Coloração mais clara que a da da fêmea. Esternitos III a VII com áreas glandulares transversais mediamente alongadas. Tergito VIII com pente póstero-marginal incompleto (ausente medianamente), com dentes curtos e de base larga.

Material examinado. BRASIL. São Paulo: Ilha Solteira, 14-xi-1993 (C. Almeida), 2 9 (ESALQ), em melancia Citrullus vulgaris; Jaboticabal, 23-i-1992 (N.M. Martinelli), 2 i e 1 o (ESALQ), em algodão Gossypium hirsutum; Mogi-Mirim, 05xi-1993 (L.R.P. Trevizan), 26 (ESALQ, BMNH e IBUNAM), em algodão; Piracicaba, 23-viii-1993 (A.R. Tavares), 17 9 (ESALQ, BMNH e IBUNAM), em girassol Helianthus annuus; idem, xi-1992 (R.C. Monteiro), 2 (ESALQ), em amendoinzeiro Arachis hypogea; idem, 16-xii-1993 (R.C. Monteiro e N.A. Canal D.), 11 q e 5 o (ESALQ), em soja Glycine max; Campinas, xi-1991 (A.L. Lourenção), 2 (ESALQ), em soja; idem, 19-i-1994 (R.C. Monteiro e J.A.

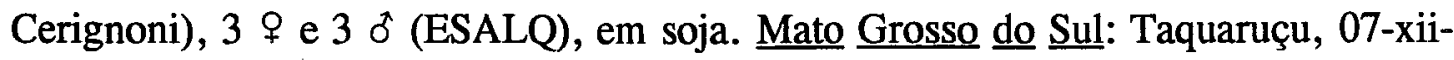




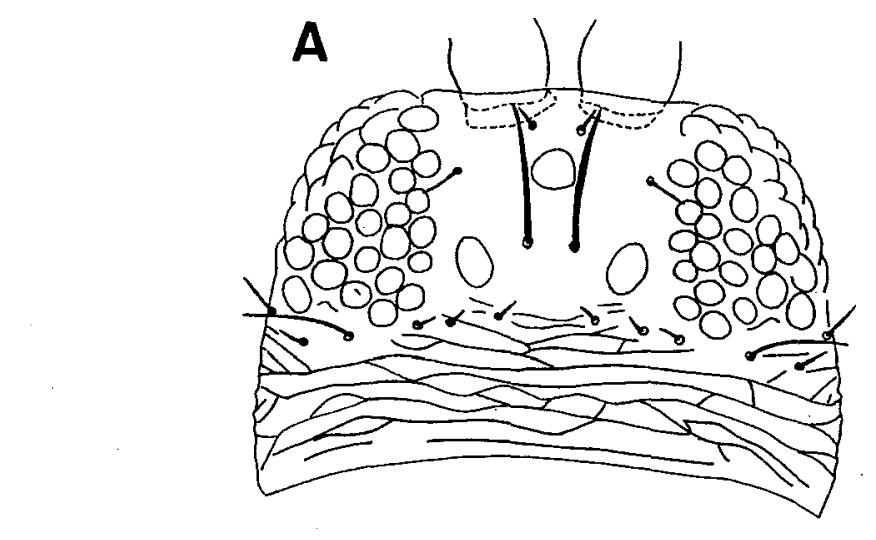

D
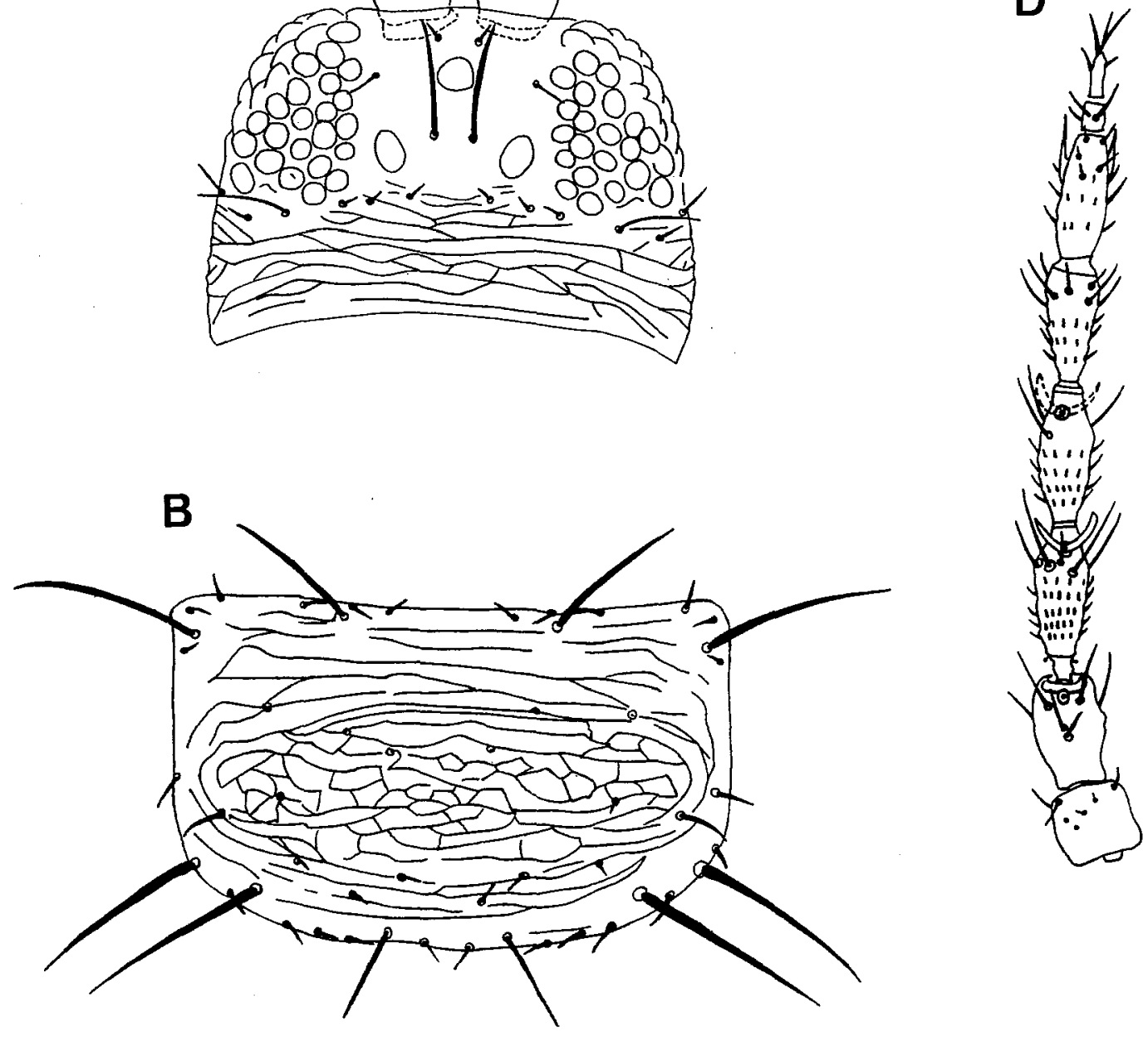

C
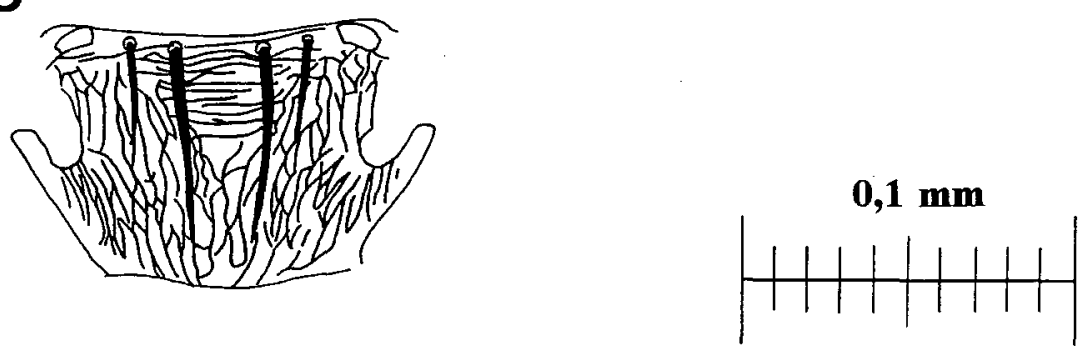

Figura 14. Frankliniella schultzei. A. cabeça (dorsal); B. pronoto; C. metanoto; D. antena. 
A

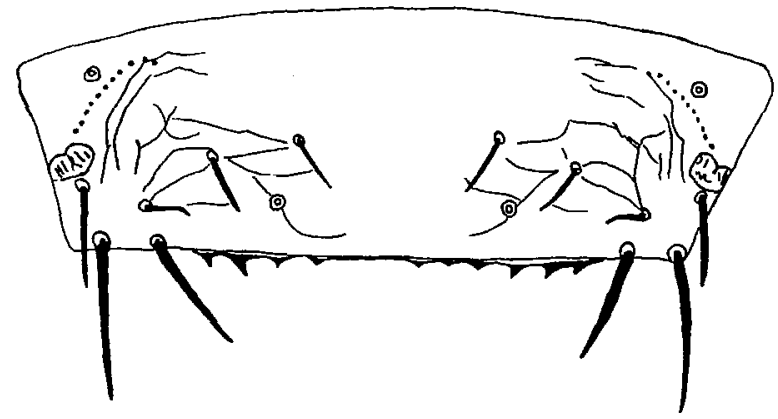

B
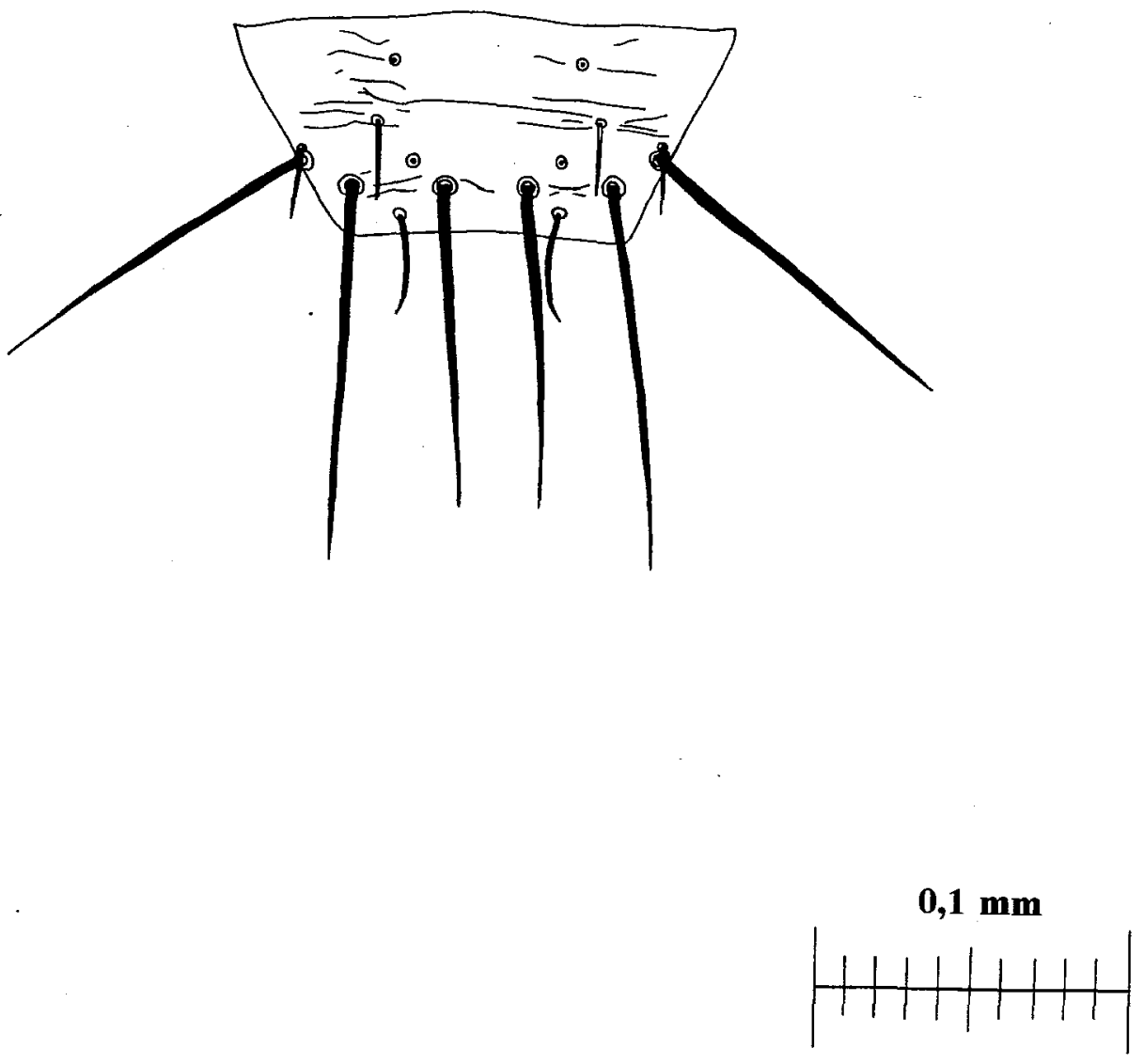

Figura 15. Frankliniella schultzei. A. tergito abdominal VIII; B. tergito abdominal IX. 
1993 (E.L. Dantas), 22 \& e 1 o (ESALQ), em algodão.

Comentários. Apresenta ampla distribuição, mas é comum e amplamente dispersa na África. Espécie polífaga, que freqüentemente ataca sorgo, amendoinzeiro, ervilha, feijoeiro, algodoeiro, cebola, tomateiro e Compositae. Também se reproduz em plantas daninhas remanescentes nos campos, após a colheita da cultura. Vetor do TSWV, ao qual as leguminosas e solanáceas são particularmente suscetíveis. Ocorre também em flores e danifica folhas jovens dentro do botão. Pode também transportar esporos de fungos, como míldios e ferrugens, de plantas infectadas (PALMER et al., 1989). Relatada em batata, fumo e tomateiro, nos Estados do Rio de Janeiro e São Paulo (SILVA et al., 1968). Coletada em soja, no Paraná, onde foi uma das espécies coletadas mais comuns (ALMEIDA et al., 1994).

\subsubsection{Heliothrips haemorrhoidalis (Bouché, 1833)}

Fêmea. Macróptera. Coloração marrom-escura; pernas, segmentos antenais III, IV, V, base do VI e ápice do VII e extremidade posterior do abdome (segmentos abdominais VIII, IX e X) amarelados.

Cabeça. Com forte esculturação reticulada, inclusive dentro do triângulo ocelar; retículos regulares e poligonais. Ponte occipital dorsal ausente. Cerdas muito pequenas, de difícil visualização (Fig. 16A). Antena com oito segmentos; segmentos I e II com reticulações poligonais; segmentos III e IV com sensilos simples e estrias transversais; segmento VII pequeno e segmento VIII bastante longo e afilado; segmentos V e VI com estrias transversais (Fig. 16C). Tarsos com um segmento.

Tórax. Pronoto quadrangular, com esculturação reticulada poligonal, exceto uma faixa mediana posterior clara; sem cerdas desenvolvidas (Fig. 16B). Mesonoto com divisão mediana incompleta (Fig. 17A). Metanoto com esculturação reticulada poligonal e 


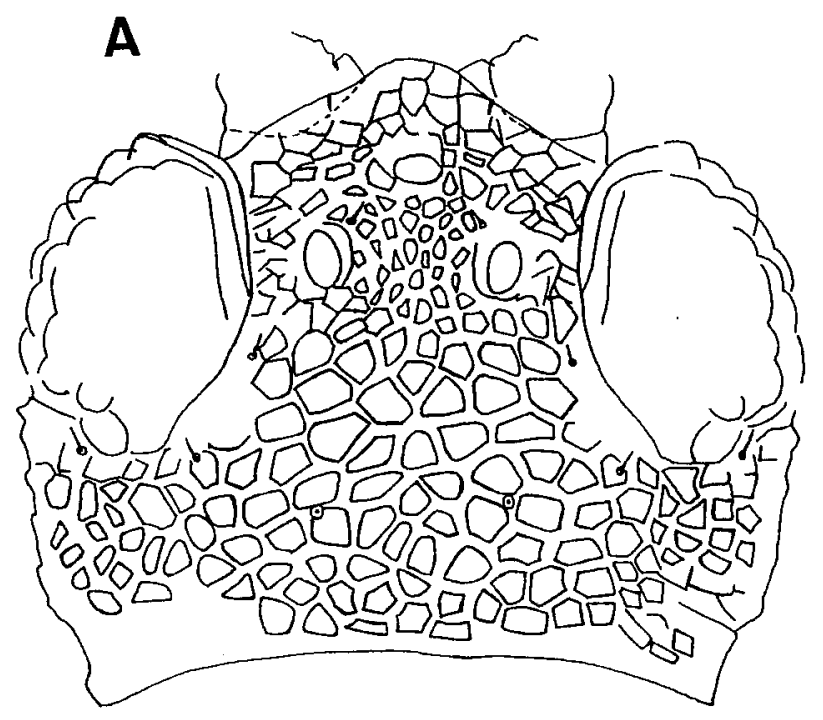

B
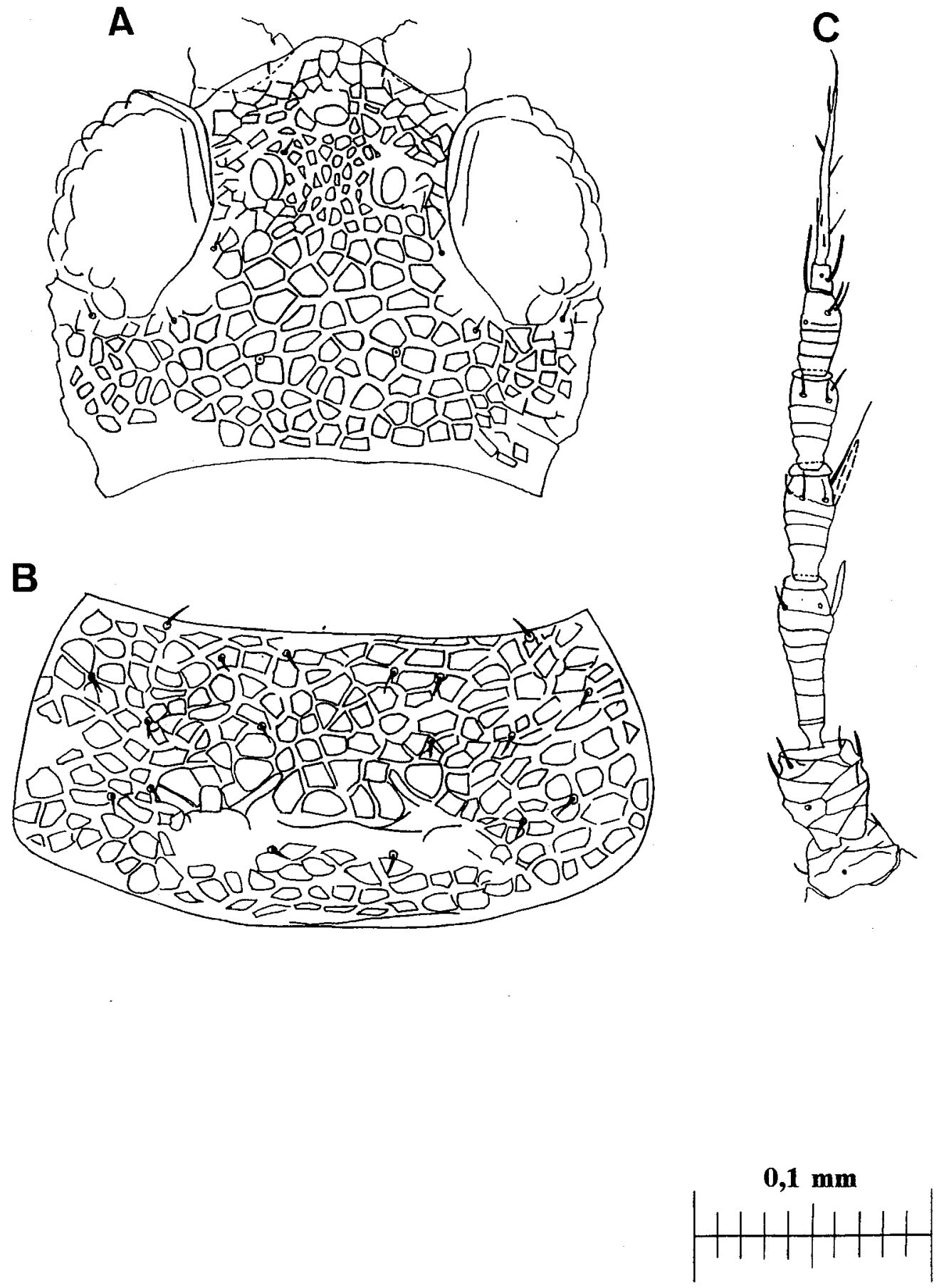

Figura 16. Heliothrips haemorrhoidalis. A. cabeça (dorsal); B. pronoto; C. antena. 
um pequeno par de cerdas inseridas um pouco acima da parte central (Fig. 17B).

Abdome. Com forte esculturação reticulada. Tergito abdominal IX com quatro cerdas longas, de mesmo tamanho, na margem posterior.

Macho. Raro (MOUND, 1976). Esternitos III a VII com uma grande área glandular transversal, estando a maior delas presente no $\mathrm{III} e$, as seguintes, decrescendo até o VII (STANNARD, 1968). É menor que a fêmea e apresenta dois pares de cerdas robustas na parte posterior do tergito IX (PALMER et al., 1989).

Material examinado. BRASIL. Minas Gerais: Carmo do Rio Claro, 04-v-1991 (Clóvis?), 9 9 (ESALQ), em citros Citrus sp.

Comentários. Segundo PALMER et al. (1989), H. haemorrhoidalis tem como origem as Américas Central e do Sul e encontra-se amplamente dispersa nos trópicos, subtrópicos e em casas-de-vegetação, nas regiões temperadas. Danifica folhas de várias culturas, desde o chá até Pinus sp., incluindo citros, abacateiro e mangueira (KONO \& PAPP, 1977). Encontrado em vários Estados do Brasil, Bahia, Rio de Janeiro, Minas Gerais, Pará, Rio Grande do Sul e São Paulo, danifica as folhas e, às vezes, as flores e/ou os frutos de várias culturas, incluindo citros (SILVA et al., 1968).

\subsubsection{Palleucothrips musae Hood, 1956}

Fêmea. Macróptera. Coloração amarela muito clara; olhos compostos com contorno marrom, bastante destacado.

Cabeça. Com esculturação reticulada na parte mediana posterior. Olhos compostos bastante destacados, com contorno marrom-escuro. Par de cerdas ocelares II 


\section{A}
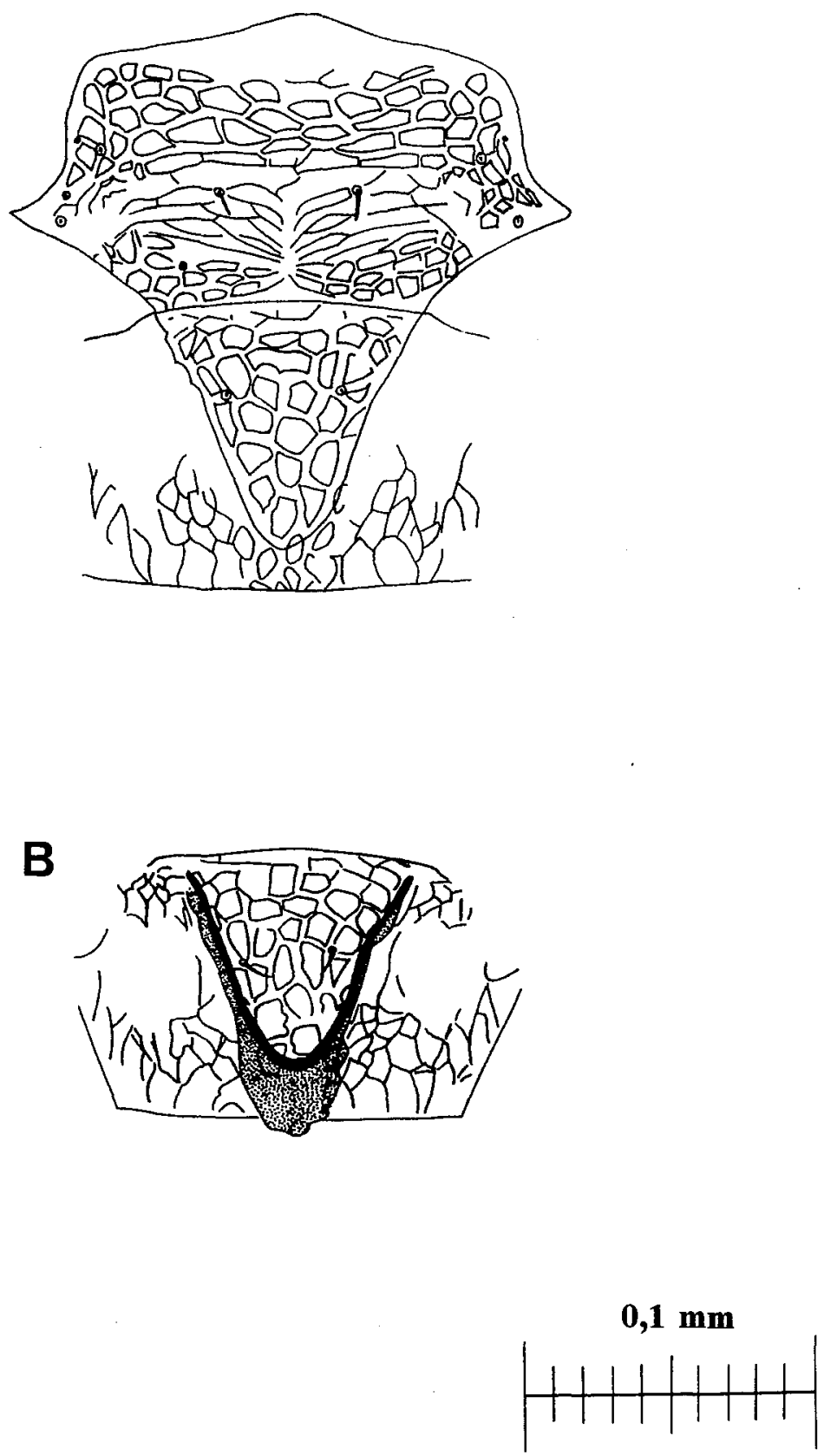

Figura 17. Heliothrips haemorrhoidalis. A. meso e metanoto; B. metanoto. 
extremamente desenvolvidas e robustas (Fig. 18A). Antena com oito segmentos; segmentos III e IV com sensilos furcados e poucas microtríquias; ápice do segmento IV com cerda bastante desenvolvida, dorsal, que quase alcança o ápice do segmento $\mathrm{V}$; segmento VIII longo e afilado (Fig. 18D). Asa com cerdas longas, robustas e com base desenvolvida, presentes na margem anterior e na parte central da asa (arranjadas irregularmente).

Tórax. Pronoto quadrangular, com fraca e reduzida esculturação transversal estriada; dois pares de cerdas póstero-angulares desenvolvidas (Fig. 18B). Metanoto com esculturação reticulada (retículos poligonais); com dois pares de cerdas pouco desenvolvidas, par mediano inserido na parte central; sensilos campaniformes ausentes (Fig. 18C); furca em formato de lira.

Abdome. Pleurotergitos com esculturação oblíqua estriada. Tergito VIII com espiráculo aproximadamente circular; ctenídeo ausente; margem posterior com expansão longa. Tergito IX com muitas microtríquias. Extremidade arredondada.

Macho. Macróptero. Coloração semelhante à da fêmea.

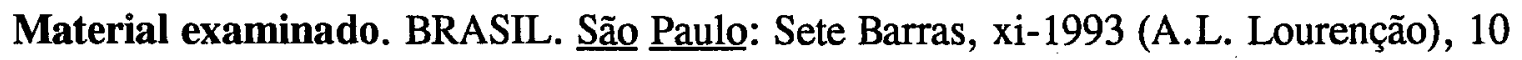
o e 1 ơ (ESALQ), em banana Musa sp.

Comentários. Essa espécie foi descrita por Hood, a partir de exemplares coletados em bananais em Quevedo, Equador. Yust ${ }^{17}$ citado por LOURENÇÃo et al. (1981) relatou os danos causados em banana. No Brasil, o primeiro relato de sua ocorrência foi feito por LOURENÇÃO et al. (1981), a partir de exemplares coletados em bananais do Vale do Ribeira (Registro e Sete Barras), no Estado de São Paulo.

${ }^{17}$ YUST, H.R. Insect pests and fruit spotting of Gros Michel banana in Ecuador. Plant Protection Bulletin, Rome, 8(2): 13-8, 1959. 

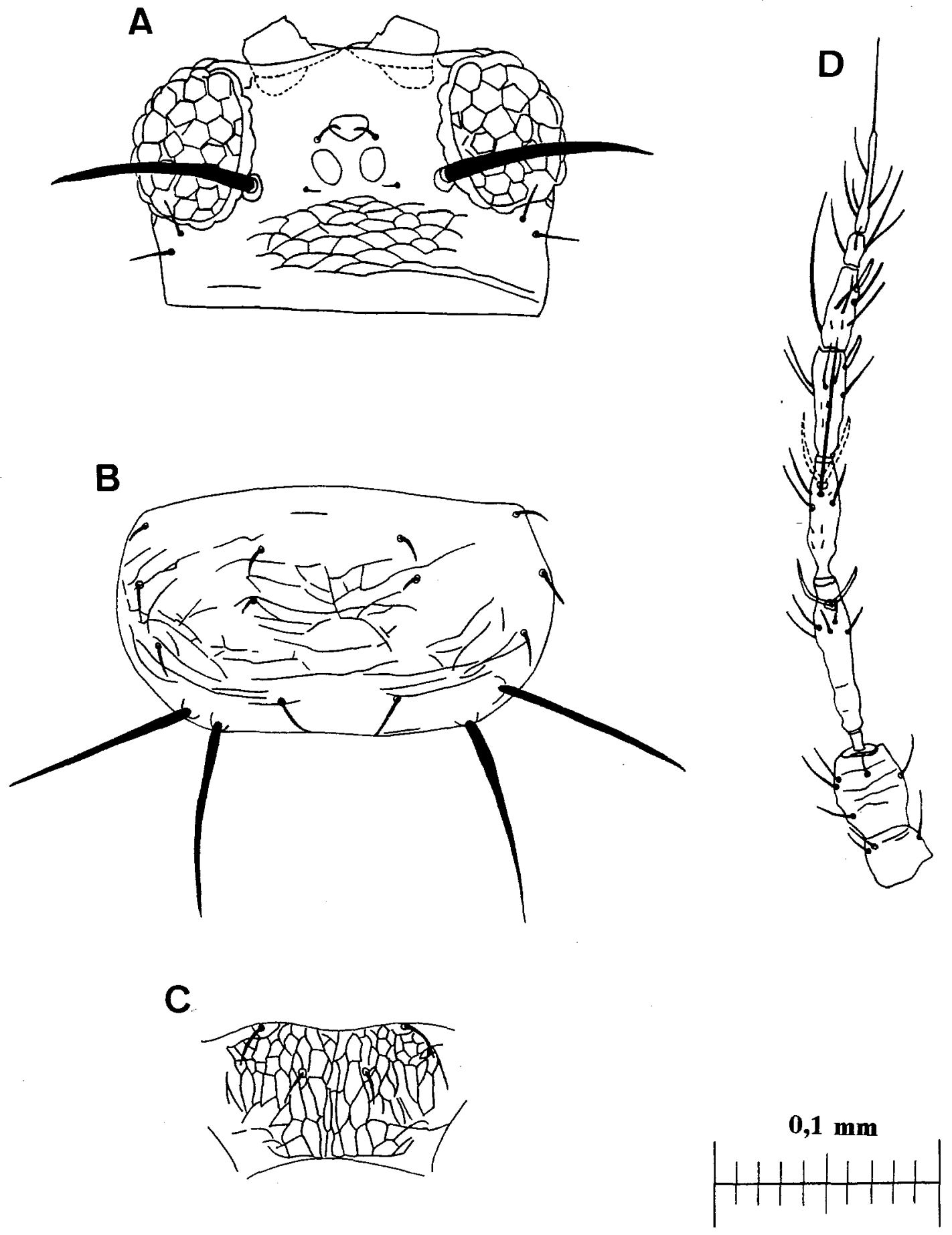

Figura 18. Palleucothrips musae. A. cabeça (dorsal); B. pronoto; C. metanoto; D. antena. 
4.3.11. Selenothrips rubrocinctus (Giard, 1913)

Fêmea. Macróptera. Coloração marrom-escura; tarsos, extremidades apicais das tíbias, base dos segmentos antenais III e V, base e ápice do segmento IV e segmentos VII e VIII amarelados.

Cabeça. Com constrição posterior e forte esculturação reticulada (inclusive entre os ocelos), exceto a extremidade posterior da cabeça; retículos poligonais. Cerdas ocelares III desenvolvidas, dentro do triângulo ocelar e um pouco maiores que a distância entre suas bases; cerdas pós-oculares relativamente desenvolvidas e de mesmo tamanho (Fig. 19A). Antena com oito segmentos; segmentos III e IV com sensilos furcados (furca do III retorcida e menor que a do IV); segmento VIII longo e afilado; segmento III com metade basal mais larga e IV com a parte central alargada; cerdas antenais, em sua maioria, bastante longas (Fig. 19D).

Tórax. Pronoto quadrangular e com esculturação transversal estriada (poucas estrias se unem); muito mais largo que longo; cerdas pouco desenvolvidas (Fig. 19B). Metanoto largo, com esculturação transversal estriada na parte mediana superior e esculturação reticulada poligonal, nas laterais, que são demarcadas por espessas linhas, cujos contornos formam um triângulo invertido; na parte lateral inferior, esculturação oblíqua estriada; par de cerdas medianas inseridas na parte central e não muito longas; par de sensilos campaniformes presentes (Fig. 19C). Asas anteriores escuras, com duas fileiras de cerdas pretas, longas e robustas; margem anterior também com cerdas escuras.

Abdome. Com esculturação reticulada; retículos laterais mais nítidos que os medianos. Linha irregular escura nos segmentos III-VIII, parecendo uma linha contínua de pequenos "u" invertidos, bastante distinta. Tergito VIII com craspedum completo, com dentes muito longos, finos e de base estreita em toda sua extensão; muitas microtríquias na parte mediana posterior. Tergito IX com cerdas b1 um pouco 


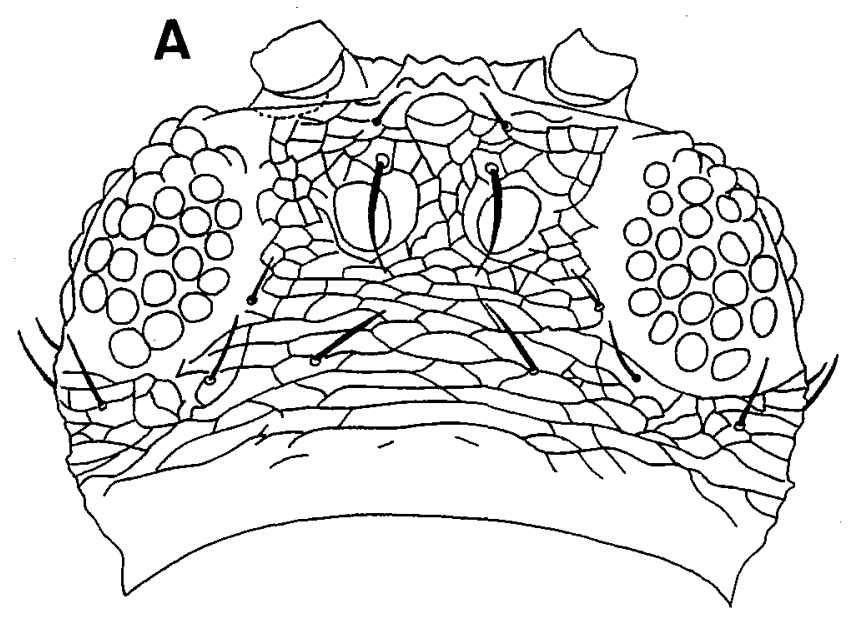

D
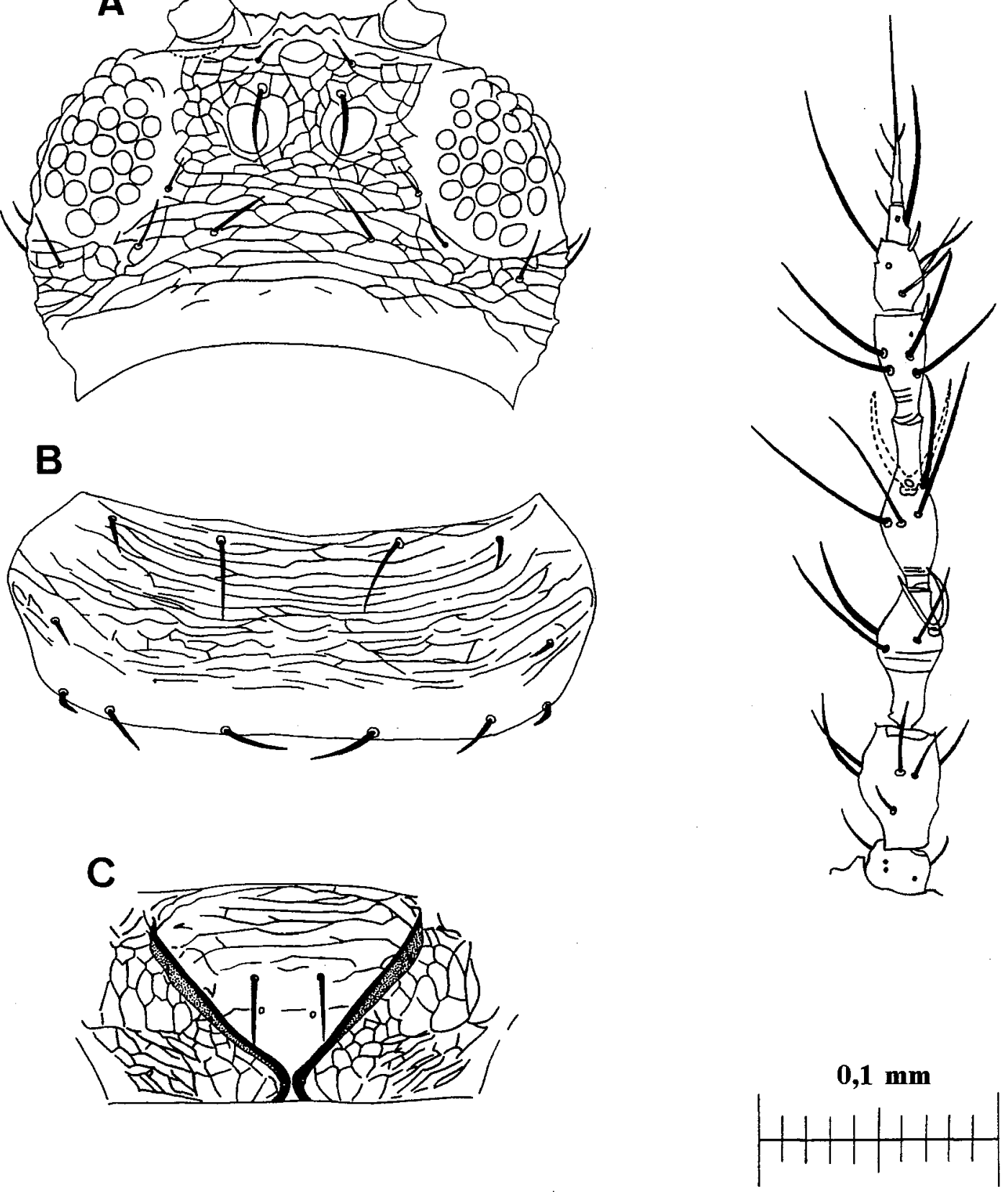

Figura 19. Selenothrips rubrocinctus. A. cabeça (dorsal); B. pronoto; C. metanoto; D. antena. 
menores que b2 (Fig. 20). Tergito $X$ não dividido.

Machos. Esternitos III a VII com pequena área glandular.

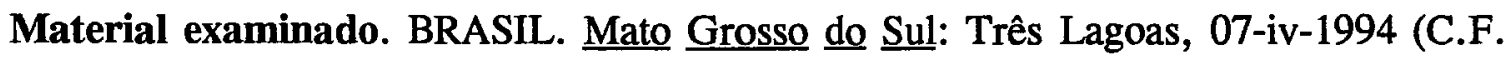
Wilcken), 5 क (ESALQ), em eucalipto Eucalyptus urophylla; idem, 17-vi-1994 (C.F. Wilcken), 8 ㅇ (ESALQ), em eucalipto.

Comentários. Conhecido como "tripes-do-cacaueiro" ou "tripes-da-faixa-vermelha" é uma espécie originalmente africana, agora pantropical, que causa danos severos à mangueira, cajueiro e cacaueiro, pela alimentação em folhas maduras (PALMER $e t$ al., 1989); particularmente comum em árvores doentes, com deficiência nutricional (FENNAH, 1965). O nome específico deve-se ao aspecto das ninfas, que são amarelo-claras e têm uma cinta vermelha nos dois primeiros segmentos abdominais. No Brasil, foi assinalada nos Estados do Amazonas, Bahia, Rio de Janeiro, Minas Gerais, Pará, Rio de Janeiro, Rio Grande do Sul e São Paulo, em várias culturas, porém não em eucalipto (SILVA et al., 1969). FIGUEROA (1973) estudou a dinâmica populacional de $S$. rubrocinctus, na região cacaueiro da Espírito Santo. Em Piracicaba, SP, é encontrado comumente em Eugenia aquea (Myrtaceae), conhecida como jambo branco, jambo aquoso e jambo do nordeste. Provavelmente, é o primeiro registro da ocorrência de $S$. rubrocinctus em eucalipto, no Brasil.

\subsubsection{Stenchaetothrips minutus (Deventer, 1906)}

Fêmea. Macróptera. Coloração marrom; pernas, parte basal das asas anteriores, segmentos antenais III e IV, parte basal dos segmentos V e VI e parte apical do II amarelados.

Cabeca. Esculturação transversal estriada na parte posterior. Cerdas ocelares III fora do 

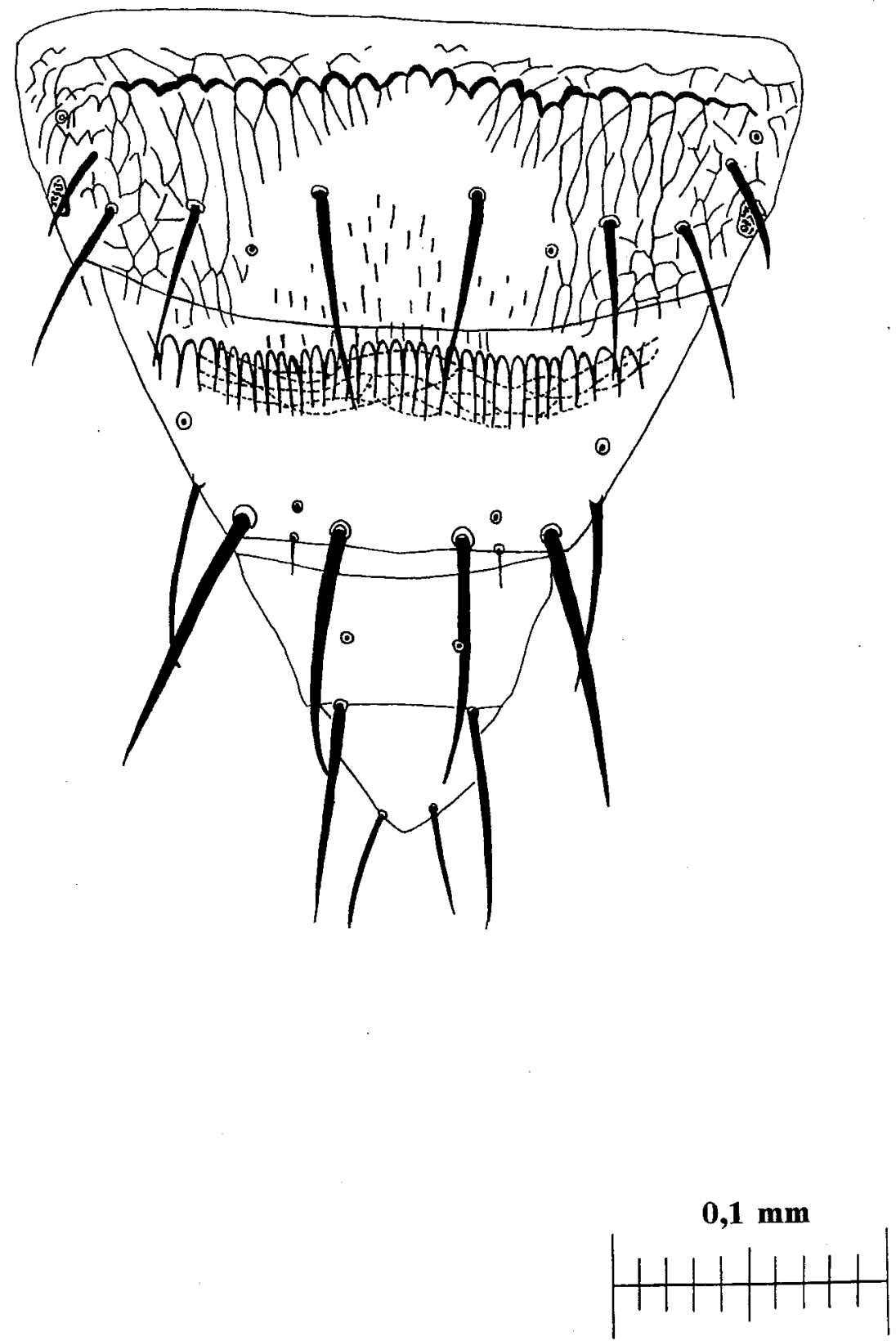

Figura 20. Selenothrips rubrocinctus. Tergitos abdominais VIII-XI. 
triângulo ocelar e tão longas quanto à distância entre suas bases; cerdas ocelares II bastante desenvolvidas e maiores que as cerdas ocelares III; cerdas pós-oculares pequenas, de mesmo tamanho, exceto dois pares (Fig. 21A). Antena com sete segmentos; segmentos III e IV com sensilos furcados; segmentos II-VI com microtríquias; segmento VII pequeno (Fig. 21D).

Tórax. Pronoto sem esculturas visíveis; dois pares de cerdas póstero-angulares desenvolvidas (Fig. 21B). Metanoto com esculturação estriada transversal no terço mediano superior; partes medianas central e inferior com esculturação longitudinal estriada; laterais com esculturação oblíqua estriada; par de sensilos campaniformes presentes (Fig. 21C). Asa com nervura anterior de cerdas incompleta. Furca do meso e metatórax sem espínula.

Abdome. Tergito VIII com pente póstero-marginal completo, com dentes longos, finos e de base estreita (pequena e circular); ctenídeo presente situado póstero-medianamente ao espiráculo. Ctenídeo também presente nos tergitos V-VII. Tergito IX com dois pares de poros. Tergito $\mathrm{X}$ quase totalmente dividido por um sulco longitudinal. Laterais dos tergitos com nítida esculturação oblíqua estriada; parte mediana com escultura transversal estriada ondulada.

Material examinado. BRASIL. S和 Paulo: Rafard, 14-vi-1994 (D. Leite), $6 q$ (ESALQ), em pimentão Capsicum annuum.

Macho. Macróptero. Áreas glandulares ovais e transversais presentes nos segmentos III-VII ou III-VIII (BHATTI \& MOUND, 1980). Tergito VIII com pente póstero-marginal ausente (LIMA, 1926).

Comentários. O gênero Stenchaetothrips compreende 14 espécies, duas delas relatadas no Brasil (Stenchaetothrips minutus, 1906 e Stenchaetothrips brasiliensis (Hood, 1954)). S. minutus é uma espécie oriental, praga secundária da cana-de-açúcar, 


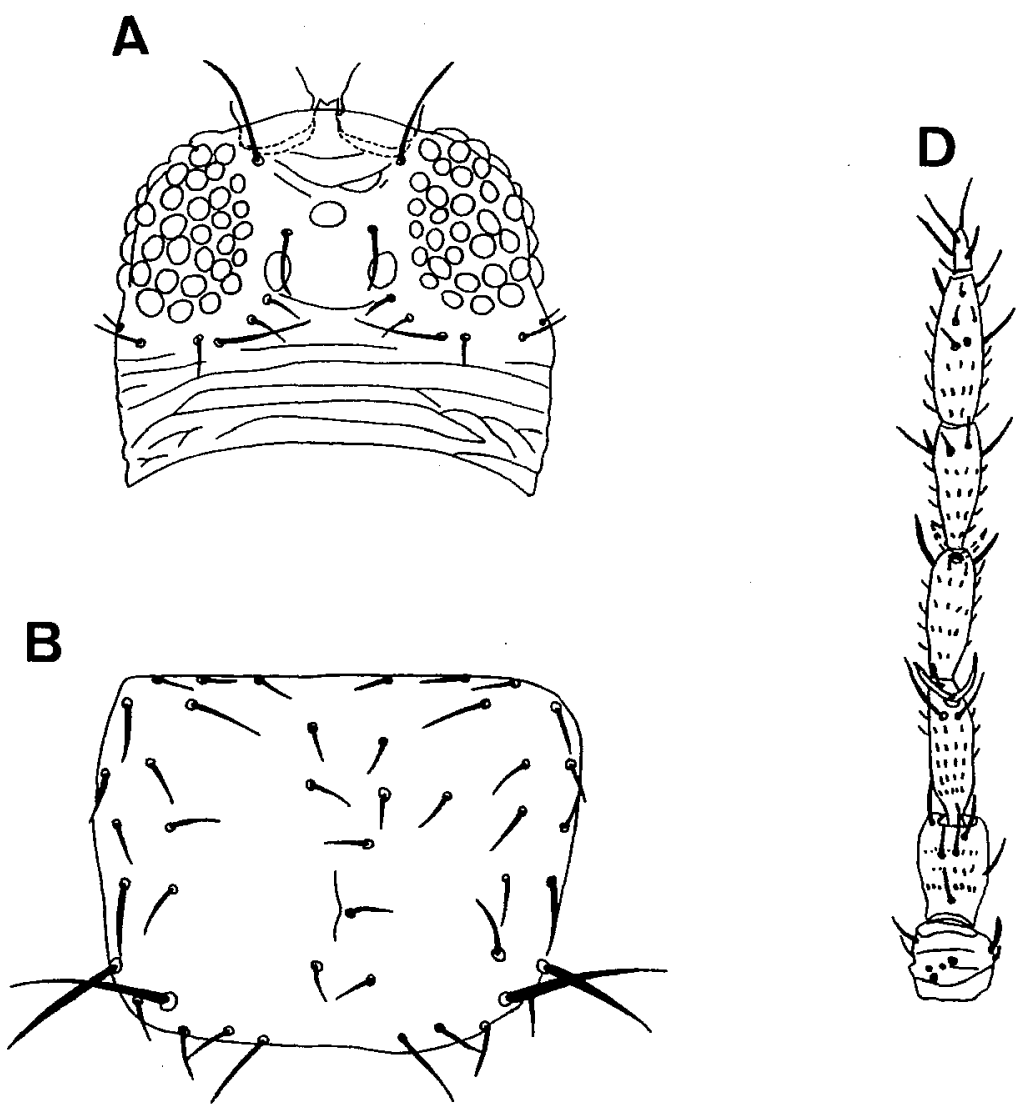

C
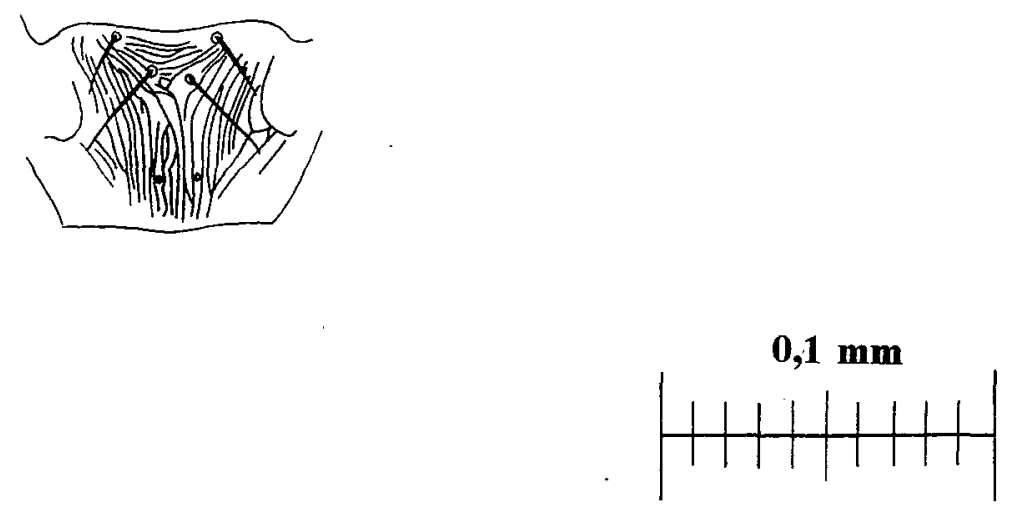

Figura 21. Stenchaetothrips minutus. A. cabeça (dorsal); B. pronoto; C. metanoto; D. antena. 
amplamente dispersa $\left(\right.$ Mound $\left.^{18}\right)$. A distribuição geográfica de $S$. minutus inclui: Índia (Tamil Nadu), Indonésia, Taiwan, Brasil, Havaí e Japão (Okinawa) (BHATTI \& MOUND, 1980). Referido por LIMA (1926) e SILVA et al. (1968) como Thrips minutus var: puttemansi LIMA, 1926, foi coletado em folhas novas de cana-deaçúcar e de cana-taquara, nos Estados do Rio de Janeiro, Rio Grande do Sul e São Paulo.

\subsubsection{Thrips palmi Karny, 1925}

Fêmea. Macróptera. Coloração amarela-clara, sem qualquer mancha acinzentada ou amarronzada, mas com cerdas do corpo enegrecidas e numerosas. A coloração dos segmentos antenais IV e $\mathrm{V}$ está sujeita a variações, podendo ser marromescura ou amarela, na metade basal.

Cabeça. Com esculturação transversal estriada (poucas estrias unidas), inclusive entre os ocelos. Cerdas ocelares I ausentes. Cerdas ocelares III fora do triângulo ocelar; cerdas pós-oculares e pós-ocelares pequenas (Fig. 22A). Crescente ocelar avermelhado. Antena com sete segmentos; segmento VII pequeno; segmentos III e IV com sensilos furcados; segmentos II-VI com microtríquias (Fig. 22D)

Tórax. Pronoto quadrangular, com fraca esculturação transversal estriada; dois pares de cerdas póstero-angulares desenvolvidas; cerdas restantes pequenas (Fig. 22B). Metanoto com o par mediano de cerdas inseridas abaixo da margem anterior, não atingindo a margem posterior; esculturação transversal estriada no terço mediano superior; terços medianos central e inferior com esculturação longitudinal estriada; laterais com esculturação oblíqua estriada, convergindo para a margem posterior; par de sensilos campaniformes presentes (Fig. 22C). Primeira nervura da asa anterior

${ }^{18}$ MOUND, L.A. (The Natural History Museum. London, UK) Comunicação pessoal, 1994. 


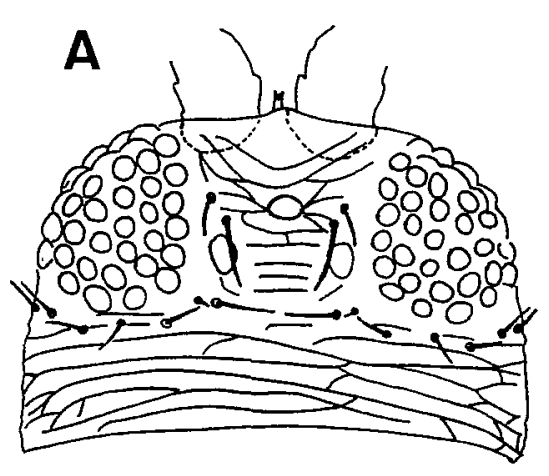

D
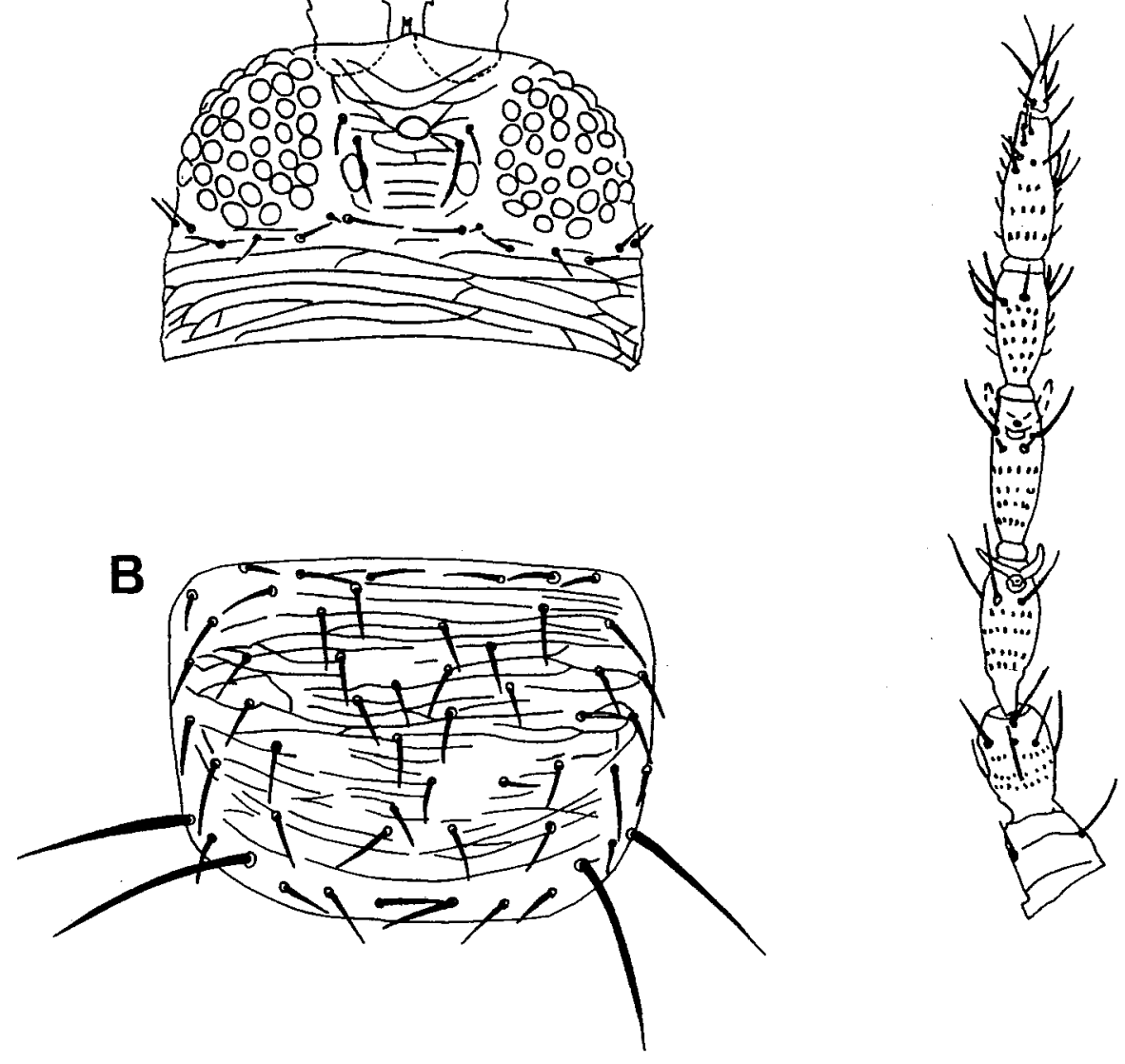

C
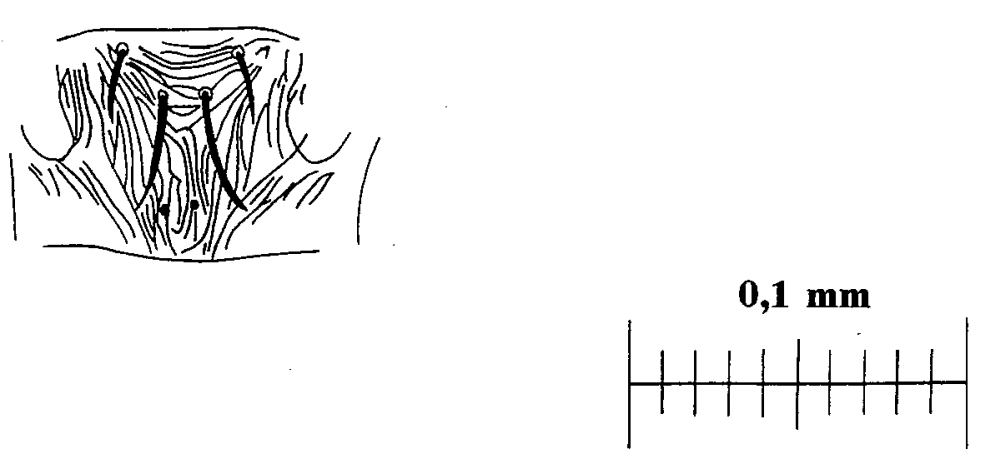

Figura 22. Thrips palmi. A. cabeça (dorsal); B. pronoto; C. metanoto; D. antena. 
uma fileira de aproximadamente doze cerdas.

Abdome. Tergito VIII com pente póstero-marginal completo, com dentes longos e finos; ctenídeo presente e situado póstero-medianamente aos espiráculos (Fig. 23B). Tergito IX com dois pares de sensilos campaniformes; cerdas b1 menores que b2 (Fig. 23C). Tergito II com quatro cerdas laterais. Tergitos medianos com cerdas discais menores que a distância entre suas bases; esculturação mediana ausente; esculturação lateral sem microtríquias. Esternitos abdominais com três pares de cerdas póstero-marginais, mas nenhuma cerda discal. Pleurotegitos sem microtríquias (Fig. 23A).

Macho. Macróptero. Semelhante à fêmea, mas menor. Tergito II, algumas vezes, com apenas três cerdas laterais. Pente póstero-marginal do tergito VIII frequentemente ausente lateralmente. Cerdas b1 do tergito IX em linha com b2, porém um pouco menores. Esternito II-VII com grande área glandular transversal.

Material examinado. BRASIL. $\underline{\text { São Paulo: }}$ ? , 25-vi-1993 (G. Groppo), 20 \& e 2 o (18 $q$ e $2 q$ na ESALQ e $2 q$ no BMNH), em tomate Lycopersicon esculentum; Itapira, 15-v-1994 (C.E. Cavenagli), 8 9 e 1 ơ (ESALQ), em pimentão Capsicum annuum; Holambra, vi-1994 (A.L. Lourenção), 4 ๆ e 1 ơ (ESALQ), em crisântemo Chrysantemum sp.; Jaguariúna, 12-iii-1994 (D. Pagotto), 12 (ESALQ), em crisântemo; Pinhalzinho, 01-vi-1994 (L.A. Marciano), 16 (ESALQ), em batata Solanum tuberosum; Paulínia, iii-1994 (A.L. Lourenção), 7 ๆ e 2 ơ (ESALQ), em pimentão; Atibaia, 08-vi-1994 (H. Tsukamoto), 24 ㅇ (ESALQ), em batata; São Miguel Arcanjo, v-1993 (O. Nakano), 9 \& (ESALQ), em pimentão; Itapetininga, 24xi-1993 (R.G.A. Gurgel), 8 \& (ESALQ), em batata; Piedade, 16-iii-1993 (R. Agnelo), 8 \& 1 ơ (ESALQ), em beringela Solanum melongena; Registro, xi-1992 (A.L. Lourenção), 1 \& (ESALQ), em beringela.

Comentários. Thrips palmi é semelhante a T. flavus Schrank, 1776, espécie também 
A

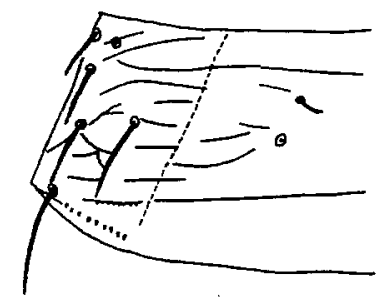

B
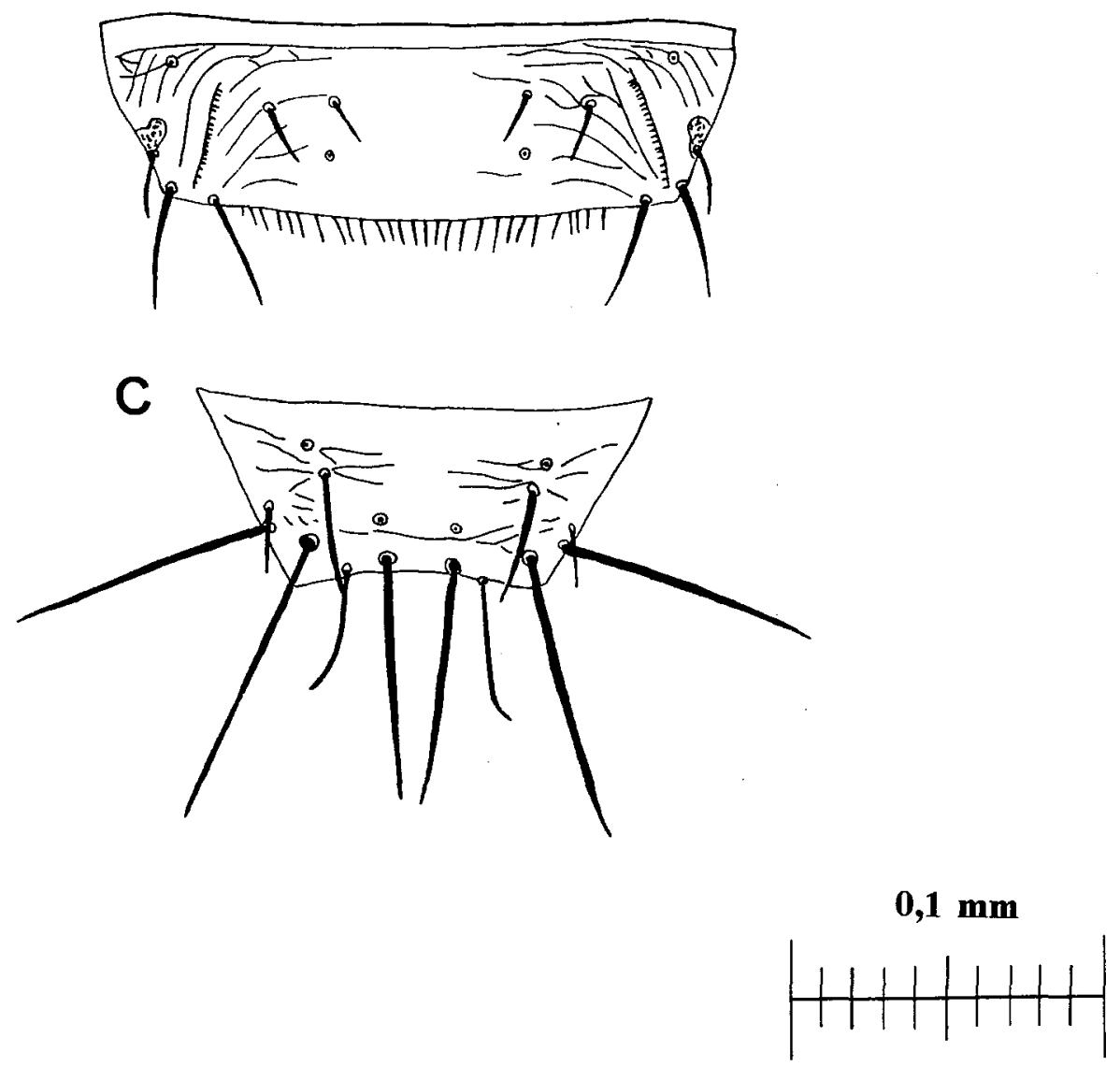

Figura 23. Thrips palmi. A. pleurotergito abdominal II; B. tergito abdominal VIII; C. tergito abdominal IX. 
amarela e comum. No entanto, diferencia-se do mesmo por apresentar as cerdas ocelares III fora do triângulo ocelar e a escultura do metanoto convergindo posteriormente. Foi redescrito por BHATTI (1980). Nos últimos 12 anos, T. palmi tornou-se, rapidamente, a principal praga das cucurbitáceas e solanáceas e ganhou uma posição de destaque em muitas regiões tropicais. É considerada uma das espécies de tripes mais prejudicial, por ser polífaga, apresentar baixa sensibilidade a um grande número de produtos químicos comerciais e alta taxa reprodutiva (KAWAI, 1990). Ataca feijoeiro, beringela, algodoeiro, cucurbitáceas, batata, melão, melancia, caupi, pimenta, fumo, pepino, crisântemo, dália, batata doce, além de diversas plantas daninhas. Sua distribuição geográfica inclui África (Mauritius, Nigéria, Reunião, Sudão), Ásia (Bangladesh, Brunei, Burma, China, Índia, Indonésia, Japão, Coréia, Malásia, Myanmar, Paquistão, Filipinas, Singapura, Sri Lanka, Taiwan, Tailândia), Australásia e Ilhas do Pacífico (Austrália, Guam, Havaí, Nova Caledônia, Ilhas Wallis, Western Samoa), América do Norte (Flórida), América Central e Caribe (Antigua, República Dominicana, Guadalupe, Guam, Martinica, Porto Rico, St. Kitts, Trinidade) e América do Sul (Guiana e Venezuela) (CAB, 1992; CERMELI \& MONTAGNE, 1990). Esse é o primeiro relato da espécie no Brasil. Extratos de folhas de tomateiro apresentam um efeito deterrente sobre $T$. palmi, causando a morte dos indivíduos em poucos dias (YASUMI et al., 1991).

\subsubsection{Thrips tabaci Lindeman, 1888}

Fêmea. Macróptera. Coloração amarelo-amarronzada ou marron clara, com manchas marrom-claras ou marrom-amareladas nos tergitos do tórax e abdome (porção mediana).

Cabeça. Com fraca esculturação transversal estriada (estrias, às vezes, unidas), inclusive dentro do triângulo ocelar. Cerdas ocelares I ausentes; cerdas ocelares III dentro do triângulo ocelar; crescente ocelar acinzentado; cerdas pós-oculares pequenas, de 
mesmo comprimento, exceto um par menor (Fig. 24A). Antena com sete segmentos; segmentos III e IV com sensilos furcados; segmentos II-VI com microtríquias; segmento VII pequeno (Fig. 24D).

Tórax. Pronoto quadrangular, com esculturação transversal estriada; cerdas numerosas e curtas, exceto em duas áreas posteriores centrais; dois pares de cerdas pósteroangulares um pouco maiores que as demais (Fig. 24B). Metanoto com esculturação reticulada (retículos poligonais) medianamente; laterais com esculturação oblíqua estriada. Sensilos campaniformes ausentes (Fig. 24C). Asa anterior com 3-7 cerdas distais.

Abdome. Tergito VIII com pente póstero-marginal completo, com dentes longos e finos; ctenídeo presente, situado póstero-medianamente ao espiráculo (Fig. 25B). Tergito IX com um par de sensilos campaniforme; cerdas b1 menores que b2 (Fig. 25C). Tergito II com três cerdas laterais. Pleurotergitos com fileiras de microtríquias (Fig. 25A). Tergitos com um par de cerdas discais, menores que a distância entre suas bases; esculturações transversal e oblíqua estriada na parte mediana (ausente no centro) e lateral. Esternitos com três pares de cerdas na margem posterior.

Macho. Macróptero. Coloração amarelo-clara, segmentos antenais II, VI e VII e metade superior dos segmentos III, IV e V marrons. Esternitos abdominais III-V com estreita área glandular transversal.

Material examinado. BRASIL. Bahia: Jequié, 01-x-1993 (J.S. Correia), $11 q$

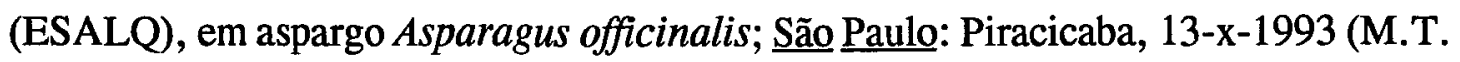
Iamauti), 17 (ESALQ e IBUNAM), em cebolinha Allium fistulosum; Campinas, vi-1993 (A.L. Lourenção), $17 q$ e 1 ơ (ESALQ e IBUNAM), em alho Allium sativum; idem, 13-ix-1993 (C. Stein), 17 (ESALQ, BMNH e IBUNAM), em alho; idem, 19-i-1994 (R.C. Monteiro e J.A. Cerignoni), 1 \& (ESALQ), em soja Glycine 

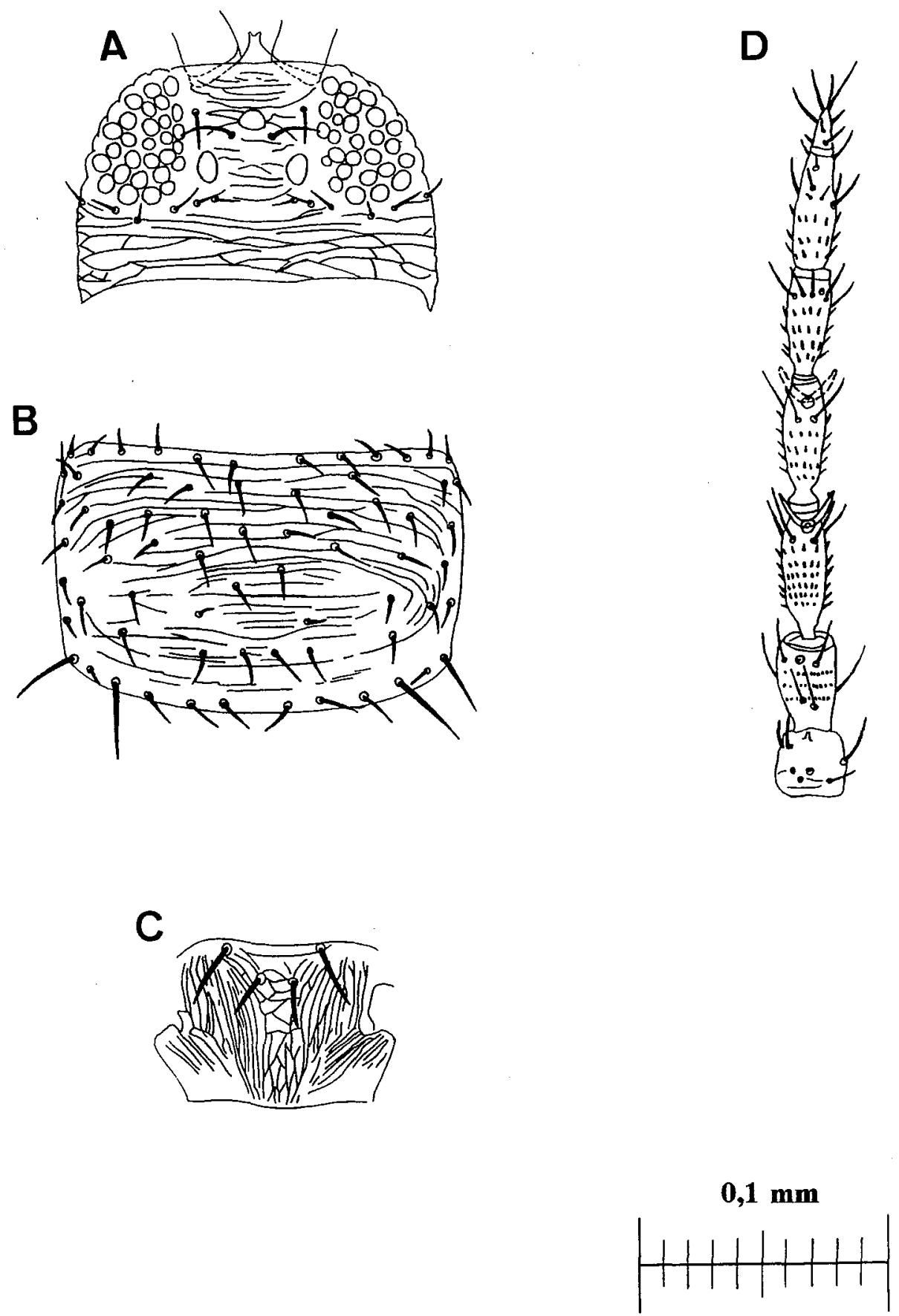

Figura 24. Thrips tabaci. A. cabeça (dorsal); B. pronoto; C. metanoto; D. antena. 
A
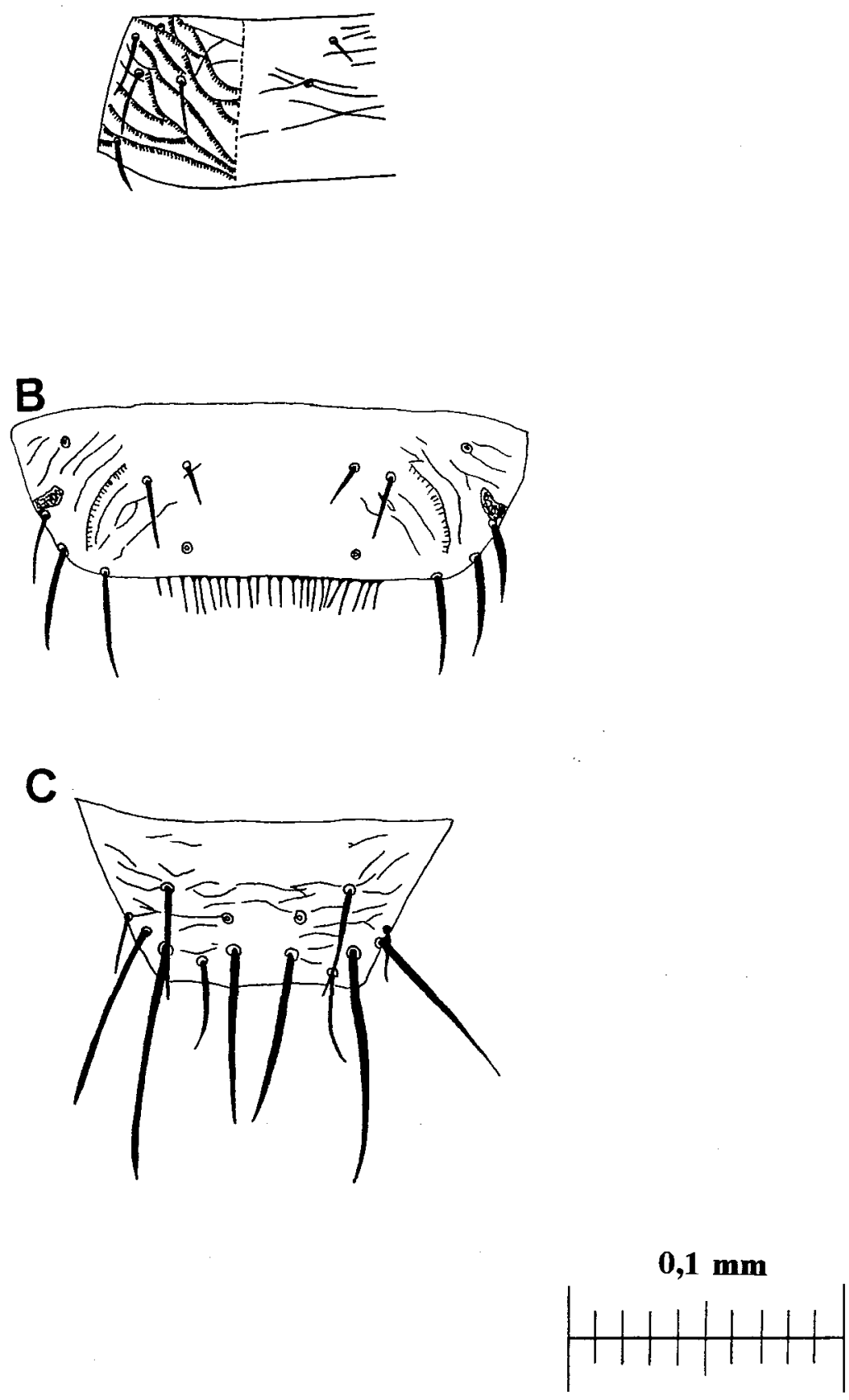

Figura 25. Thrips tabaci. A. pleurotergito abdominal II; B. tergito abdominal VIII; C. tergito abdominal IX. 
max; Paraná: Londrina, 27-x-1993 (P.M.O.J. Neves), 21 9 (ESALQ e IBUNAM), em cebola Allium cepa.

Comentários. É uma espécie cosmopolita, de origem européia. O "tripes-da-cebola" ou "tripes-do-fumo" apresenta uma grande gama de hospedeiros. É uma importante praga agrícola, não somente pelo dano de alimentação, mas também por ser vetor de viroses: TSWV, no tomateiro e PYSV (Pineapple Yellow Spot Virus), no abacaxizeiro. $O$ crescente ocelar com pigmentação acinzentada (cinza ou cinza-amarelado) diferencia T. tabaci das demais espécies de Thrips, cujo pigmento ocelar é vermelho (NAKAHARA, 1991a). A presença de quatro ou mais (ao invés de três ou menos) cerdas apicais na nervura anterior da asa anterior e a limitação das áreas glandulares do macho para os segmentos III-V também são características que permitem o reconhecimento da espécie (BHATTI, 1980). Aparentemente, as cebolas são os hospedeiros preferidos de T. tabaci, embora também se alimente de outras plantas. Relatado em várias plantas, nos Estados da Bahia, Minas Gerais, Rio de Janeiro, Rio Grande do Sul, Santa Catarina e São Paulo (SILVA et al., 1968). SATO (1989) fez um estudo sobre avaliação de dano e controle de T. tabaci, na cultura da cebola. RAMIRO (1972) estudou o comportamento de variedades de cebola em relação ao ataque de T. tabaci, assim como seu controle. 


\section{CONCLUSÕES}

5.1. Enneothrips flavens Moulton, 1941 é a única espécie freqüentemente encontrada na cultura do amendoinzeiro.

5.2. Thrips tabaci Lindeman, 1888 é comum em liliáceas e não foi coletado em algodoeiro, apesar de tradicionalmente ser mencionado como praga dessa cultura; Frankliniella schultzei (Trybom, 1910) foi coletado nessa cultura.

5.3. Thrips palmi Karny, 1925 é registrado pela primeira vez no Brasil.

5.4. Frankliniella occidentalis (Pergande, 1895) é registrado pela primeira vez no Brasil, com coleção depositária dos exemplares. 


\section{REFERÊNCIAS BIBLIOGRÁFICAS}

ALMEIDA, A.M.R.; NAKAHARA, S.; SOSA-GOMEZ, D.R. Thrips species identified in soybean fields in Brazil. Anais da Sociedade Entomológica do Brasil, Londrina, 23(2): 363-5, 1994.

AMIN, P.W. \& PALMER, J.M. Identification of groundnut Thysanoptera. Tropical Pest Management, London, 31(4): 286-91, 1985.

ANANTHAKRISHNAN, T.N. Bionomics of thrips. Annual Review of Entomology, Stanford, 38: 71-92, 1993.

BATISTA, G.C. Determinação do período crítico de ataque do tripes Enneothrips

- (Enneothripiella) flavens Moulton, 1941 (Thysanoptera - Thripidae) no amendoim, Arachis hypogea L., em cultura "das águas", e efeito de inseticidas sistêmicos no seu controle. Piracicaba, 1971, 127p. (Doutorado - Escola Superior de Agricultura "Luiz de Queiroz"/USP).

BATISTA, G.C.; GALLO, D.; CARVALHO, R.P.L. Determinação do período crítico de ataque do tripes do amendoim, Enneothrips flavens Moulton, 1941, em cultura das águas. Anais da Sociedade Entomológica do Brasil, Itabuna, 2(1): 45-53, 1973.

BHATTI, J.S. Species of the genus Thrips from India (Thysanoptera). Systematic Entomology, Oxford, 5: 109-66, 1980.

BHATTI, J.S. \& MOUND, L.A. The genera of grass- and cereal-feeding Thysanoptera related to the genus Thrips (Thysanoptera: Thripidae). Bulletin of Entomology, New Delhi, 21(1/2): 1-22, 1980.

BERGESON, G.B.; ATHOW, K.L.; LAVIOLETTE, F.A.; THOMASINE, M. 
Transmission, movement and vector relationships of tobacco ringspot virus in soybean. Phytopathology, Gainesville, 54: 723-6, 1964.

CASTRO, P.R.C.; PITELLI, R.A.; PASSILONGO, R.L. Variações na ocorrência de algumas pragas do amendoinzeiro relacionadas com o desenvolvimento da cultura. Anais da Sociedade Entomológica do Brasil, Itabuna, 1(1): 5-16, 1972.

CERMELI, M.L. \& MONTAGNE, A.A. Thrips palmi Karny (Thysanoptera, Thripidae) nueva plaga para Venezuela. Boletín de Entomología Venezolana, Maracay, 5(20): 192, 1990.

COMMONWEALTH AGRICULTURAL BUREAUX INTERNATIONAL. International Institute of Entomology. Distribution maps of pests. London, 1992. (Series A: Map, 480).

FENNAH, R.G. Nutricional factors associated with seasonal population increase of cacao thrips, Selenothrips rubrocinctus (Giard) (Thysanoptera), on cashew, Anacardium occidentale. Bulletin of Entomological Research, Wallingford, 53: 681-713, 1962.

FIGUEROA, G.H.S. Dinâmica populacional do Selenothrips rubrocinctus (Giard, 1901) (Thysanoptera: Thripidae), na região cacaueira do Espírito Santo, Brasil. Piracicaba, 1973, 65p. (Mestrado - Escola Superior de Agricultura "Luiz de Queiroz"/USP).

FUNDERBURK, J. Ecology and management of flower thrips in a mixed agronomic and vegetable production system. In: CONGRESO DE LA SOCIEDAD COLOMBIANA DE ENTOMOLOGÍA, 20., Cali, 1993. Memorias. Cali, Sociedad Colombiana de Entomologia, 1993. p. 322-9.

GASTON, K.J. \& MOUND, L.A. Taxonomy, hypothesis testing and the biodiversity crisis. Proceedings of the Royal Society of London B, London, 251: 139-42, 1993.

HOOD, J.D. New species of Frankliniella (Thysanoptera). Bulletin of the Brooklyn Entomological Society, Lancaster, 20(2): 71-83, 1925.

HOOD, J.D. Some new or little Thysanoptera of the family Phlaeothripidae. Revista de Entomologia, Rio de Janeiro, 5(2): 159-99, 1935. 
HOOD, J.D. Studies in Neotropical Thysanoptera. I. Revista de Entomologia, Rio de Janeiro, 6(2): 248-79, 1936a.

HOOD, J.D. Studies in Neotropical Thysanoptera. II. Revista de Entomologia, Rio de Janeiro, 6(3/4): 424-60, 1936b.

HOOD, J.D. Studies in Neotropical Thysanoptera. III. Revista de Entomologia, Rio de Janeiro, 7(1): 96-115, 1937a.

HOOD, J.D. Studies in Neotropical Thysanoptera. IV. Revista de Entomologia, Rio de Janeiro, 7(2/3): 225-96, $1937 \mathrm{~b}$.

HOOD, J.D. Studies in Neotropical Thysanoptera. V. Revista de Entomologia, Rio de Janeiro, 7(4): 486-530, 1937c.

HOOD, J.D. New Thysanoptera from Florida and North Carolina. Revista de Entomologia, Rio de Janeiro, 8(3/4): 348-420, 1938a.

HOOD, J.D. Studies in Neotropical Thysanoptera. VI. Revista de Entomologia, Rio de Janeiro, 8(1/2): 161-87, $1938 \mathrm{~b}$.

HOOD, J.D. Studies in Neotropical Thysanoptera. VII. Revista de Entomologia, Rio de Janeiro, 9(1/2): 218-47, 1938c.

HOOD, J.D. Studies in Neotropical Thysanoptera. VIII. Revista de Entomologia, Rio de Janeiro, 9(3/4): 404-26, $1938 \mathrm{~d}$.

HOOD, J.D. Notes on Chirothrips, with descriptions of two new species (Thysanoptera). Revista de Entomologia, Rio de Janeiro, 10(2): 461-71, 1939.

HOOD, J.D. A century of new american Thysanoptera. I. Revista de Entomologia, Rio de Janeiro, 11(1/2): 530-83, 1940.

HOOD, J.D. A century of new american Thysanoptera. II. Revista de Entomologia, Rio de Janeiro, 12(1/2): 139-243, 1941a.

HOOD, J.D. A century of new american Thysanoptera. III. Revista de Entomologia, Rio de Janeiro, 12(3): 547-678, 1941b.

HOOD, J.D. Brasilian Thysanoptera. I. Revista de Entomologia, Rio de Janeiro, 20(1-3): 3-88, 1949.

HOOD, J.D. Brasilian Thysanoptera. II. Revista de Entomologia, Rio de Janeiro, 
21(1/2): 1-113, 1950.

HOOD, J.D. Brasilian Thysanoptera. VI. Revista Brasileira de Entomologia, São Paulo, 4: 51-160, 1956.

HOOD, J.D. Six new Thysanoptera from Brazil. Revista Brasileira de Entomologia, São Paulo, 9: 57-68, 1960.

JACOT-GUILLARMOD, C.F. Catalogue of the Thysanoptera of the world (parts 1-4, Terbrantia; parts 5-6, Tubulifera). Annals of the Cape Provincial Museums (Natural History), Grahamstown, 7: 1-1724, 1970-1979.

JACOT-GUILLARMOD, C.F. \& BROTHERS, D.J. Catalogue of the Thysanoptera of the world (Part 7). Annals of the Cape Provincial Museums (Natural History), Grahamstown, 17(1): 1-94, 1986.

JAGER, C.M. \& BUTÔT, R.P.T. Chrysanthemum resistance to two types of thrips (Frankliniella occidentalis Pergande) feeding damage. Proceedings of Experimental and Applied Entomology, Amsterdam, 4(2): 27-31, 1993.

JOHANSEN, R.M. Una especie nueva de Aeolothripis Haliday (Insecta, Thysanoptera: Aeolothripidae), de baja California sur, Mexico. Anales del Instituto de Biologia. Universidad Autonoma del México. Série Zoologia, México, 60(2): 185-90, 1989a.

JOHANSEN, R.M. Estado actual del conocimento acerca del genero Heterothrips Hood, 1908 (Insecta, Thysanoptera: Thripidae) en Mexico y, descripcion de tres especies nuevas. Anales del Instituto de Biologia. Universidad Autonoma del México. Série Zoologia, México, 60(3): 321-40, $1989 \mathrm{~b}$.

JOHANSEN, R.M. \& MOJICA, A.M. Dos especies nuevas de Frankliniella Karny (Insecta, Thysanoptera: Thripidae), del grupo intonsa, del eje volcanico transversal de Mexico. Anales del Instituto de Biologia. Universidad Autónoma del México. Série Zoologia, México, 60(2): 191-8, 1989.

KAISER, W.J.; WYATT, S.D.; PESHO, G.R. Natural hosts and vectors of tobacco streak virus in eastern Washington. Phytopatology, Gainesville, 72: 1508-12, 1982.

KAWAI, A. Control of Thrips palmi Karny in Japan. Japan Agricultural Research 
Quartely, Tokyo, 24: 43-8, 1990.

KIRK, W.D.J. A key to the larvae os some common australian flower thrips (Insecta: Thysanoptera) with a host-plant survey. Australian Journal of Zoology, East Melbourne, 35: 173-85, 1987.

KONO, T. \& PAPP, C.S. Thrips. In: . Handbook of agricultural pests.

Sacramento, Depto. Food and Agriculture/Division of Plant Industry, 1977. p. 89114.

LEWIS, T. Thrips; their biology, ecology and economic importance. London, Academic Press, 1973, 349p.

LEWIS, T. An introduction to the Thysanoptera; a survey of the group. In: INTERNATIONAL CONFERENCE ON THRIPS, Burlington, 1989. Towards understanding Thysanoptera; proceedings, edited by B.L. Parker and others. Radnor, USDA/Forest Service/Northeastern Forest Experiment Station, 1991. p. 3-22. (USDA. General Technical Report, NE-147).

LIMA, A.C. Ordem Thysanoptera. In: . Insetos do Brasil. Rio de Janeiro, ENA, 1938. t. 1, p. 405-52.

LIMA, A.C. A propósito de uma comunicação do Dr. Puttemans, sobre o mosaico da canna de assucar. Chácaras e Quintais, São Paulo, 34(1): 30-2, 1926.

LOURENÇÃO, A.L.; MOREIRA, R.S.; ROSSETO, C.J. Palleucothrips musae Hood, 1956 danificando banana no Brasil. In: CONGRESSO BRASILEIRO DE FRUTICULTURA, 6., Recife, 1981. Anais. Recife, 1981. p. 1353-6.

MESSIEHA, M. Transmission of tobacco ringspot virus by thrips. Phytopatology, Gainesville, 59: 943-3, 1969.

MOULTON, D. The Thysanoptera of South America (I). Revista de Entomologia, São Paulo, 2(4): 451-84, 1932.

MOULTON, D. The Thysanoptera of South America (II). Revista de Entomologia, Rio de Janeiro, 3(1): 96-133, 1933a.

MOULTON, D. The Thysanoptera of South America (III). Revista de Entomologia, Rio de Janeiro, 3(2): 227-62, $1933 \mathrm{~b}$.

MOULTON, D. The Thysanoptera of South America (IV). Revista de Entomologia, 
Rio de Janeiro, 3(3): 385-419, $1933 \mathrm{c}$.

MOULTON, D. The Thysanoptera of South America (conclusion). Revista de Entomologia, Rio de Janeiro, 3(4): 447-58, 1933d.

MOULTON, D. Thysanoptera from Minas Geraes, Brazil. Revista de Entomologia, Rio de Janeiro, 9(3/4): 374-82, 1938.

MOULTON, D. Thysanoptera from Minas Geraes, Brazil (second paper). Revista de Entomologia, Rio de Janeiro, 12(1/2): 314-22, 1941.

MOULTON, D. The genus Frankliniella Karny, with keys for the determination of species (Thysanoptera). Revista de Entomologia, Rio de Janeiro, 19(1/2): 55-114, 1948.

MOUND, L.A. The identity of the greenhouse thrips Heliothrips haemorrhoidalis (Bouché) (Thysanoptera) and the taxonomic significance of spanandric males. Bulletin of Entomological Research, Wallingford, 66: 179-80, 1976.

MOUND, L.A. Thrips; the ideal opportunists. In: CONGRESO DE LA SOCIEDAD COlOMBIANA DE ENTOMOLOGIA, 20., Cali, 1993. Memorias. Cali, Sociedad Colombiana de Entomologia, 1993. p. 316-21.

MOUND, L.A. \& HEMING, B.S. Thysanoptera. In: COMMONWEALTH SCIENTIFIC AND INDUSTRIAL RESEARCH ORGANIZATION. The insects of Australia. Carlton, Melbourne University Press, 1991. p. 510-5.

MOUND, L.A. \& NAKAHARA, S. The genus Frankliniella (Thysanoptera, Thripidae): character assessment at generic and specific levels. In: BHATTI, J.S., ed. Advances in Thysanopterology, New Delhi, Scientia Publishing, 1993. p. 287-95.

MOUND, L.A. \& PALMER, J.M. Grass-flower infesting thrips of the genus Chirothrips Haliday in Australia. Journal of the Australian Entomological Society, Brisbane, 11: 332-39, 1972.

MOUND, L.A. \& PALMER, J.M. Identification, distribution and host-plants of the pest species of Scirtothrips (Thysanoptera: Thripidae). Bulletin of Entomological Research, Wallingford, 71: 467-79, 1981.

MOUND, L.A. \& PITKIN, B.R. Microscopic whole mounts of thrips (Thysanoptera). 
Entomologist's Gazette, Northamptonshire, 23: 121-5, 1972.

MOUND, L.A. \& WALKER, A.L. Terebrantia (Insecta: Thysanoptera). Fauna of New Zealand, Wellington, 1: 1-140, 1982.

MOUND, L.A.; RETANA, A.P.; DU HEAUME, G. Claves ilustradas para las familias y los géneros de Terebrantia (Insecta: Thysanoptera) de Costa Rica Y Panamá. Revista de Biología Tropical, San Jose, 41(3): 709-27, 1993.

NAKAHARA, S. Review of Thrips hawaiiensis and revalidation of T. florum (Thysanoptera: Thripidae). Proceedings of the Entomological Society of Washington, Washington, 87(4): 864-70, 1985.

NAKAHARA, S. Generic reassigments of north american species currently assigned to the genus Sericothrips Haliday (Thysanoptera: Thripidae). Proceedings of the Entomological Society of Washington, Washington, 90(4): 480-3, 1988a.

NAKAHARA, S. Preliminary study of facetal pigmentation in the compound eyes of Terebrantia (Thysanoptera). Acta Phytopathologica et Entomologica Hungarica, Budapest, 23(3-4): 321-9, 1988 b.

NAKAHARA, S. Systematics of Thysanoptera, pear thrips and other economic species. In: INTERNATIONAL CONFERENCE ON THRIPS, Burlington, 1989. Towards understanding Thysanoptera; proceedings, edited by B.L. Parker and others. Radnor, USDA/Forest Service/Northeastern Forest Experiment Station, 1991a. p. 41-59. (USDA. General Technical Report, NE-147).

NAKAHARA, S. Two new species of Caliothrips (Thysanoptera: Thripidae) and a key to the neartic species. Journal of the New York Entomological Society, New York, 99(1): 97-103, $1991 \mathrm{~b}$.

PALMER, J.M. Identification of the common thrips of Tropical Africa (Thysanoptera: Insecta). Tropical Pest Management, London, 36(1): 27-49, 1990.

PALMER, J.M. \& WETTON, M.N. A morphometric analysis of the Thrips hawaiiensis (Morgan) species-group (Thysanoptera: Thripidae). Bulletin of Entomological Research, Wallingford, 77: 397-406, 1987.

PALMER, J.M.; MOUND, L.A.; HEAUME, G.J. Thysanoptera. Wallingford, CAB, 1989. 74p. (Cie guides to insects of importance to man, 2). 
PAPAVERO, N., org. Fundamentos práticos de taxonomia zoológica: coleções, bibliografia, nomenclatura. Belém, Museu Paraensi Emílio Goeldi; Sociedade Brasileira de Entomologia, 1983. 252 p.

PRIESNER, H. Genera Thysanopterorum. Bulletin de la Societé Fouad I ${ }^{\text {er }} \mathbf{D}^{‘}$ Entomologie, Le Caire, 33: 31-157, 1949a.

PRIESNER, H. Studies on the genus Chirothrips Hal.. Bulletin de la Societé Fouad $I^{\text {er }} D^{\prime}$ Entomologie, Le Caire, 33: 159-74, 1949b.

RADAELLI, D.C. \& FERNANDES, R.G. Nova praga da parreira no Estado. Boletim Agronômico, Porto Alegre, 8(94-96): 39-40, 1944.

RAMIRO, Z.A. Comportamento de variedades e controle do Thrips tabaci Lindeman, 1888, em culturas de cebola (Allium cepa L.). Piracicaba, 1972, 144p. (Doutorado - Escola Superior de Agricultura "Luiz de Queiroz"/USP).

REED, E.M. Thysanoptera. In: COMMONWEALTH SCIENTIFIC AND INDUSTRIAL RESEARCH ORGANIZATION. The insects of Australia. Carlton, Melbourne University Press, 1973. p.458-64.

ROSSETO, C.J.; DE SANTIS, L.; PARADELA FILHO, O. Espécies de tripses coletados em culturas de feijoeiro. Bragantia, Campinas, 33(2): IX-XIV, 1974.

SAKIMURA, K. Frankliniella fusca, an additional vector for the Tomato Spotted Wilt Virus, with notes on Thrips tabaci, another vector. Phytopatology, Gainesville, 53(4): 412-5, 1963.

SAKIMURA, K. \& O'NEILL. Frankliniella, redefinition of genus and revision of minuta group species (Thysanoptera: Thripidae). Washington, USDA, 1979. 49p. (Technical Bulletin, 1572).

SATO, M.E. Avaliação de dano e controle do Thrips tabaci Lindeman, 1888 na cultura da cebola (Allium cepa L.). Piracicaba, 1989, 93p. (Mestrado - Escola Superior de Agricultura "Luiz de Queiroz"/USP).

SILVA, A.G.A.; GONÇALVES, C.R.; GALVÃO, D.M.; GONÇALVES, A.J.L.; GOMES, J.; SILVA, M.N.; SIMONI, L. Ordem Thysanoptera. In: Quarto catálogo de insetos que vivem nas plantas do Brasil. Rio de Janeiro, Ministério da Agricultura, 1968. t.1., pt. 2, p. 18-33. 
SILVA, A.L. Estudo de aplicações econômicas de inseticidas para o controle do tripes Enneothrips (Enneothripiella) flavens Moulton, 1941 (Thysanoptera - Thripidae) no amendoim, Arachis hypogea L., e importância da época de ocorrência da praga. Piracicaba, 1977, 83p. (Mestrado - Escola Superior de Agricultura "Luiz de Queiroz"/USP).

STANNARD, L.J. The Thrips, or Thysanoptera of Illinois. Illinois Natural History Survey Bulletin, Urbana, 29(4): 215-552, 1968.

YASUMI, K.; SHINOHARA, T.; HORIIKE, M.; HIRANO, C. Effect of tomato leaf constituintes on survival of Thrips palmi Karny (Thysanoptera: Thripidae). Japanese Journal of Applied Entomology and Zoology, Tokyo, 35(4): 311-6, 1991. Apud Review of Agricultural Entomology. Série A, Wallingford, 80(8): 718, agosto, 1992. (Resumo).

WIJKAMP, I.; van LENT, J.; KORMELINK, R.; GOLDBACH, R. ; PETERS, D. Virus-vector interactions during the transmission of tospoviruses by thrips. Proceedings of Experimental and Applied Entomology, Amsterdam, 4(2): 1938, 1993. 